\title{
Amphipathic Barbiturates as Mimics of Antimicrobial Peptides and the Marine Natural Products Eusynstyelamides with Activity against Multi-resistant Clinical Isolates
}

Marianne H. Paulsen, Magnus Engqvist, Dominik Ausbacher, Trude Anderssen, Manuel K. Langer, Tor Haug, Glenn R. Morello, Laura E. Liikanen, Hans-Matti Blencke, Johan Isaksson, Eric Juskewitz, Annette Bayer,* and Morten B. Strøm*

Cite This: J. Med. Chem. 2021, 64, 11395-11417

Read Online

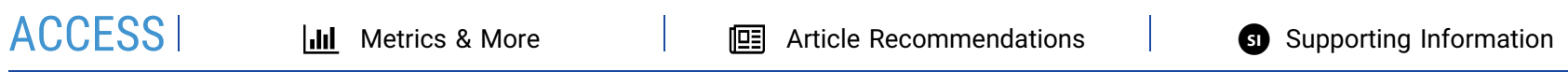

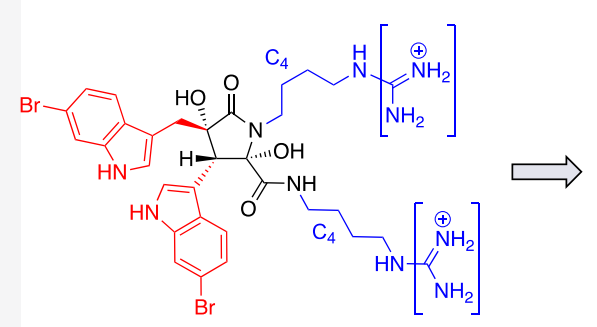

Eusynstyelamides

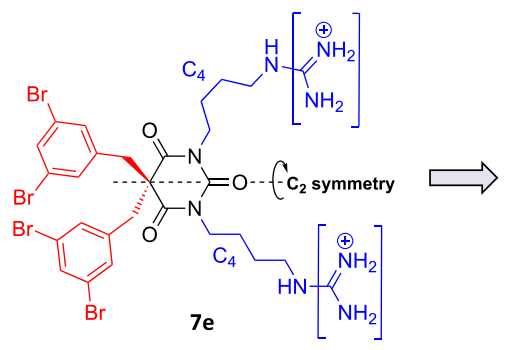

Amphipathic barbiturates

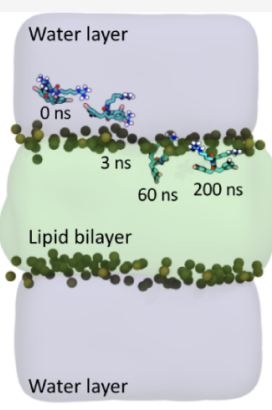

MIC: $2-8 \mu \mathrm{g} / \mathrm{mL}$ with in vivo efficacy in mice

ABSTRACT: We report a series of synthetic cationic amphipathic barbiturates inspired by the pharmacophore model of small antimicrobial peptides (AMPs) and the marine antimicrobials eusynstyelamides. These $N, N^{\prime}$-dialkylated-5,5-disubstituted barbiturates consist of an achiral barbiturate scaffold with two cationic groups and two lipophilic side chains. Minimum inhibitory concentrations of $2-8 \mu \mathrm{g} / \mathrm{mL}$ were achieved against 30 multi-resistant clinical isolates of Gram-positive and Gram-negative bacteria, including isolates with extended spectrum $\beta$-lactamase-carbapenemase production. The guanidine barbiturate 7 e (3,5-di-Br) demonstrated promising in vivo antibiotic efficacy in mice infected with clinical isolates of Escherichia coli and Klebsiella pneumoniae using a neutropenic peritonitis model. Mode of action studies showed a strong membrane disrupting effect and was supported by nuclear magnetic resonance and molecular dynamics simulations. The results express how the pharmacophore model of small AMPs and the structure of the marine eusynstyelamides can be used to design highly potent lead peptidomimetics against multi-resistant bacteria.

\section{INTRODUCTION}

There is a desperate need for developing new antimicrobial agents to meet the worldwide emergence and spread of resistant bacteria. ${ }^{1}$ Resistant bacteria are currently causing deaths of 33,000 European patients annually, and the worst scenarios estimate 10 million deaths by 2050 per year if no measures are effectuated. ${ }^{2,3}$ WHO announced in their Global action plan on antimicrobial resistance that access to and appropriate use of existing and new antimicrobial drugs are absolutely mandatory to maintain the ability to treat serious infections. ${ }^{4}$ Increasing antimicrobial resistance has also dramatic consequences for common medical interventions in cancer treatment, caesarean sections, and organ transplantations. Large pharmaceutical companies show nevertheless little interest in antimicrobial drug development, mainly due to economic reasons. Academia and smaller research institutions are now conceivably the most important contributors for discovery and synthesis of new lead compounds for antimicrobial drug development.

The eusynstyelamides are in this setting a fascinating class of antimicrobials isolated from the marine Arctic bryozoan Tegella cf. spitzbergensis and the Australian ascidian Eusynstyela latericius. ${ }^{5,6}$ The eusynstyelamides display moderate antimicrobial activity, and a method for the synthesis of $( \pm)$-eusynstyelamide $\mathrm{A}$ is reported. ${ }^{5,7}$ An intriguing structural feature of the eusynstyelamides is that they consist of two cationic groups

Received: April 23, 2021

Published: July 27, 2021 


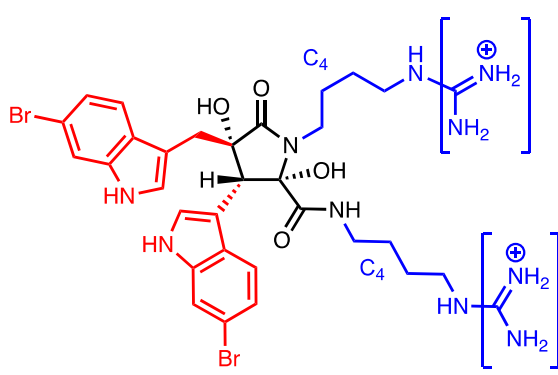

Eusynstyelamides

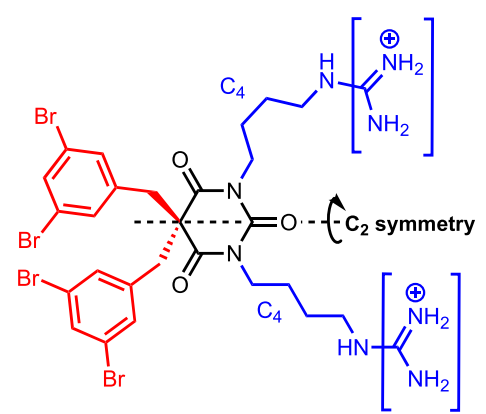

$6 \mathbf{e} / 7 \mathbf{e}$

Figure 1. General structures of the marine antimicrobials eusynstyelamides (left) and the novel amphipathic barbiturates 6e (3,5-di-Br) (amine) and $7 \mathrm{e}(3,5-\mathrm{di}-\mathrm{Br})$ (guanidine) (right). Brackets imply variations between cationic amine and guanidine groups. The eusynstyelamides can have different combinations of amine and guanidine groups, ${ }^{5}$ but in the present study, both cationic groups were identical in the synthesized amphipathic barbiturates.

\section{Series 6: Amine barbiturates}

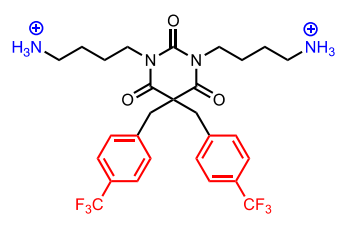

$6 \mathbf{a}\left(4-\mathrm{CF}_{3}\right)$

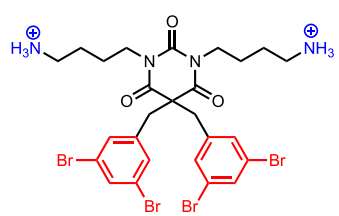

6e (3,5-di-Br)

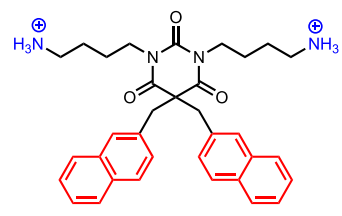

6b (2-Nal)

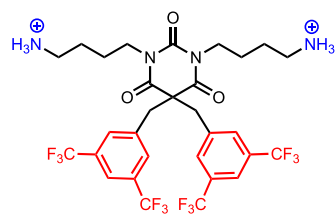

$\mathbf{6 f}\left(3,5-\mathrm{di}-\mathrm{CF}_{3}\right)$

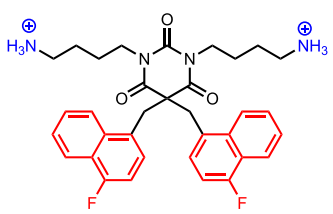

6c (4-F-1-Nal)

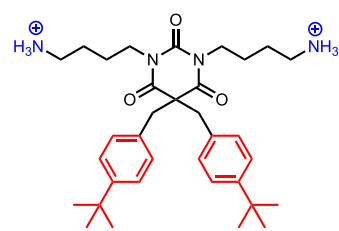

$6 \mathrm{~g}(4-\mathrm{tBu})$

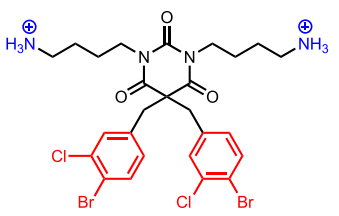

6d $(3-\mathrm{Cl}, 4-\mathrm{Br})$

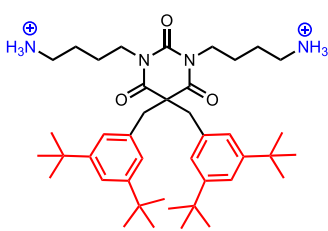

6h $(3,5-\mathrm{di}-\mathrm{tBu})$

Series 7: Guanidine barbiturates<smiles>NC(=O)NCCCCN1CC(=O)N(CCCCNC(N)=O)C(=O)C(Cc2ccc(Br)cc2)(Cc2ccc(Br)cc2)C1=O</smiles>

$7 \mathrm{a}\left(4-\mathrm{CF}_{3}\right)$

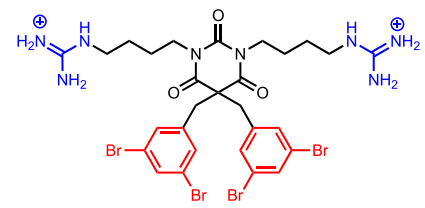

7e (3,5-di-Br)

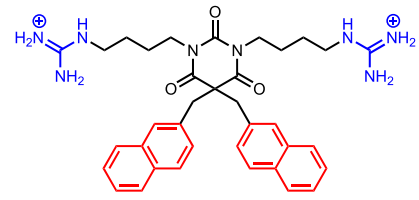

7b (2-Nal)

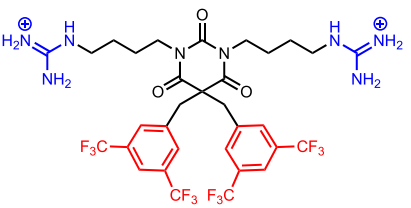

7f $\left(3,5-\right.$ di- $\left.-\mathrm{CF}_{3}\right)$

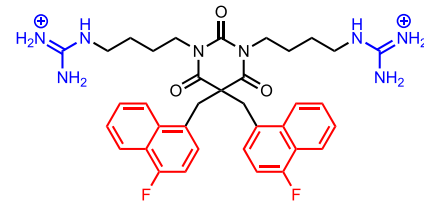

7c (4-F-1-Nal)

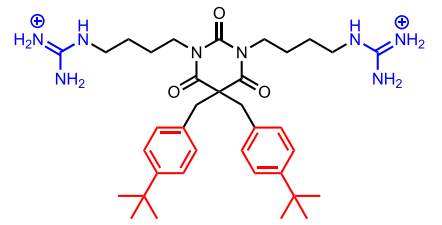

$7 \mathrm{~g}(4-\mathrm{tBu})$

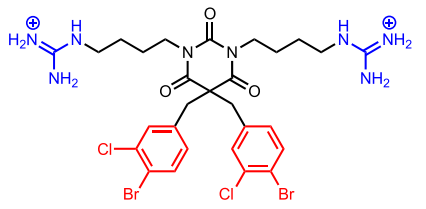

7d (3-Cl-4-Br)

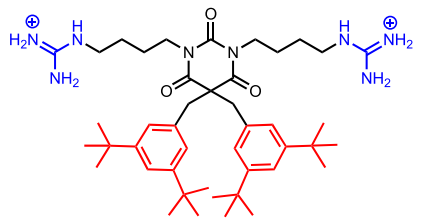

7h $(3,5-\mathrm{di}-\mathrm{tBu})$

Figure 2. Structures of the synthesized amphipathic amine barbiturates (series 6) and guanidine barbiturates (series 7) investigated for antimicrobial activity. The cationic groups have TFA $^{-}$as the counterion.

(amine or guanidine) and two lipophilic groups attached to a five-membered dihydroxybutyrolactam ring (Figure 1). This amphipathic structural arrangement of cationic and lipophilic groups satisfies the pharmacophore model of small antimicrobial peptides (AMPs) that we and others have studied extensively by design of peptidomimetics of AMPs [also named synthetic mimics of AMPs (SMAMPs)]..$^{8-11}$ AMPs play a crucial part of innate immunity in virtually all species and constitute the first line of defense against infections by bacteria, virus, fungi, and parasites. ${ }^{12-14}$ Natural AMPs are however rather large cationic peptides $(+2$ to +9$)$ consisting of 12-50 amino acid residues where $20-50 \%$ are lipophilic residues. They have an amphipathic characteristic that is essential for their membrane disruptive mode of action against bacteria. $^{12,15}$ The limitation of AMPs as drugs is related to their pharmacokinetic properties, such as low proteolytic stability, low oral bioavailability, and potential immunogenicity. ${ }^{16}$ The design of SMAMPs can offer a solution to these limitations. 
Scheme 1. Successful Strategy for the Synthesis of Target Amphipathic Barbiturates ${ }^{a}$<smiles>CCOC(=O)CC(=O)OCC</smiles><smiles>[13CH2]CC1(C[18O])C(=O)N(CCCCCN)C(=O)N(CCCCN)N(CCCCBr)C1=O</smiles>

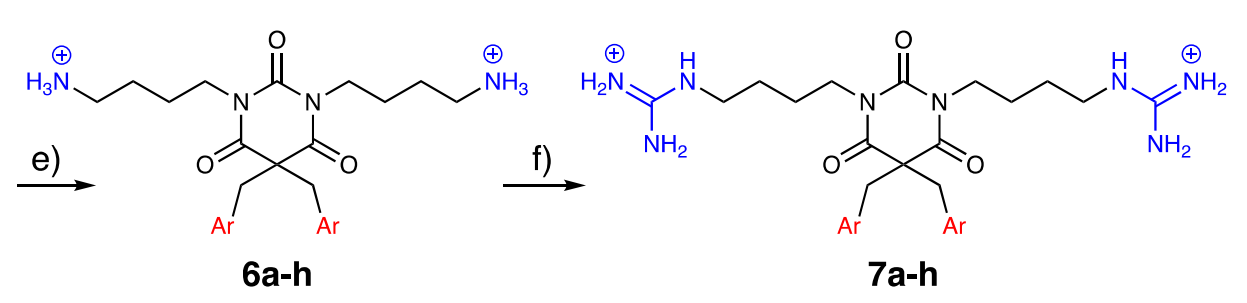

${ }^{a}$ Conditions: (a) $\mathrm{ArCH}_{2} \mathrm{Br}$, base, and DMF; (b) urea, NaH, and DMF; (c) 1,4-dibromobutane, $\mathrm{K}_{2} \mathrm{CO}_{3}$, and DMF; (d) NaN 3 and DMF; (e) (i) $\mathrm{NaBH}_{4}$, 1,3-propanedithiol, and THF:isopropanol 1:1 and (ii) $\mathrm{Boc}_{2} \mathrm{O}$; (iii) $\mathrm{CH}_{2} \mathrm{Cl}_{2} / \mathrm{TFA}$; and (f) (i) $\mathrm{N}$-Boc-1H-pyrazole-1-carboxamidine and THF and (ii) $\mathrm{CH}_{2} \mathrm{Cl}_{2}$ /TFA. Purified using C-18 flash chromatography. The Ar groups are depicted in Figure 2.

In the present study, we report a peptidomimetic amphipathic scaffold inspired by the marine antimicrobials eusynstyelamides and fulfilling the pharmacophore model of small AMPs (Figure 1). A barbiturate ring was used as a structurally simplified mimic of the more complex dihydroxybutyrolactam ring of the eusynstyelamides, providing a scaffold without stereogenic centers. Different lipophilic and cationic groups could then be introduced on the barbiturate scaffold and provide a variety of amphipathic barbiturates (Figure 2). Selection of lipophilic side chains was based on our previous work with SMAMPs. ${ }^{17,18}$ The present amphipathic barbiturates were then investigated for their antimicrobial activity against bacterial reference strains and multi-resistant clinical isolates, and toxicity against human cell lines. One selected compound was investigated in vivo using a peritonitis model in mice to determine the efficacy against Gram-negative clinical isolates. The mode of action was studied in vitro using two luciferase-based membrane assays. To gain further insights into the membrane interaction of the amphipathic barbiturates, conformational analysis by nuclear magnetic resonance (NMR) in a membrane mimicking environment and molecular dynamics (MD) simulations of the interaction progression of compounds with an inner Escherichia coli cell membrane were performed.

\section{RESULTS AND DISCUSSION}

Synthesis. Reported methods for the synthesis of substituted barbiturates include the condensation of alkylated malonate esters with urea, ${ }^{19-21}$ cyclization with $N$-alkylated urea and diethyl malonate or malonic acid, ${ }^{22,23}$ Knoevenagel condensation of barbituric acid and aldehydes or ketones, $^{20,24,25}$ and alkylation of barbituric acid. ${ }^{26}$

We first focused on a divergent synthetic strategy to gain quick access to tetrasubstituted, amphipathic barbiturates by cyclization of $N, N^{\prime}$-dialkylated ureas and disubstituted diethyl malonates. Unfortunately, no suitable reaction conditions for the cyclization of a number of malonate derivatives with $N, N^{\prime}$ dialkylated urea with a short $\mathrm{C}_{2}$ linker to the cationic groups were found (see the Supporting Information; Section 1 for details). Depending on the reaction conditions, the dialkylated urea proved to be either unreactive, decomposed, or led to undesired side products. As this strategy did not deliver the desired results, we turned our attention to a different approach.

The condensation of dialkylated malonate esters with urea followed by $\mathrm{N}$-alkylation became a successful strategy for the synthesis of amphipathic barbiturates (Scheme 1). Symmetrically disubstituted malonates $\mathbf{2 a}-\mathbf{g}$ were obtained from diethyl malonate $\mathbf{1}$ by dialkylation with the appropriate arylmethyl halides and were subsequently cyclized with urea by treatment with $\mathrm{NaH}$ in dimethylformamide (DMF) to provide the 5,5disubstituted barbiturates $\mathbf{3} \mathbf{a}-\mathbf{h}$ in yields of $70-92 \%$. Dry conditions were imperative to the yield. Cyclization of malonate $2 \mathrm{f}\left(3,5-\mathrm{di}_{-} \mathrm{CF}_{3}\right)$ gave low yields $(27 \%)$ due to decarboxylation under the reaction conditions. The 5,5disubstituted barbiturates $3 \mathbf{a}-\mathbf{h}$ were alkylated with an excess of 1,4-dibromobutane under basic conditions $\left(\mathrm{K}_{2} \mathrm{CO}_{3}\right.$ in DMF) to afford $N, N^{\prime}$-dialkylated barbiturates $4 \mathbf{a}-\mathbf{h}$ in $40-$ $96 \%$ yield. These were converted to the corresponding azides $\mathbf{5 a}-\mathbf{h}$ with $\mathrm{NaN}_{3}$ (2-3 equiv) in DMF (68-100\% yield). Reduction of the azides to amines with $\mathrm{NaBH}_{4}$ and a catalytic amount of propane-1,3-dithiol, ${ }^{27}$ and subsequent Bocprotection, provided Boc-protected diamines after purification by flash chromatography. Boc-protection was important to increase the yield and ease the purification.

Deprotection with 2,2,2-trifluoroacetic acid (TFA) provided the target amine barbiturates $6 \mathbf{a}-\mathbf{h}[>95 \%$ purity as determined by analytical $\mathrm{C}_{18}$ reversed phase (RP) HPLC]. The amine barbiturates $\mathbf{6 a}-\mathbf{h}$ were guanylated with $\mathrm{N}$-Boc- $1 \mathrm{H}$ pyrazole-1-carboxamidine in tetrahydrofuran (THF) and purified before the Boc-protecting groups were removed. 
Table 1. Antimicrobial Activity (MIC in $\mu \mathrm{g} / \mathrm{mL}$ ) of Synthesized Compounds against Antibiotic Susceptible Gram-Positive and Gram-Negative Reference Strains and Hemolytic Activity $\left(\mathrm{EC}_{50}\right.$ in $\left.\mu \mathrm{g} / \mathrm{mL}\right)$ against Human Erythrocytes (RBC)

\begin{tabular}{|c|c|c|c|c|c|c|c|c|}
\hline \multirow[b]{2}{*}{ Comp. } & \multirow[b]{2}{*}{ (side chain) } & \multirow[b]{2}{*}{$\mathrm{Clog} P^{b}$} & \multirow[b]{2}{*}{$M_{\mathrm{w}}{ }^{c}$} & \multicolumn{4}{|c|}{ Antimicrobial activity $^{a}$} & \multirow{2}{*}{$\frac{\mathrm{RBC}}{\text { tox. }}$} \\
\hline & & & & S. a & C. $g$ & E. $c$ & P. a & \\
\hline $6 a$ & $\left(4-\mathrm{CF}_{3}\right)$ & 3.52 & 814.62 & 64 & 4 & 128 & 64 & $>398$ \\
\hline $6 b$ & $(2-\mathrm{Nal})$ & 3.82 & 778.75 & 8 & 1 & 16 & 16 & 250 \\
\hline $6 c$ & (4-F-1-Nal) & 3.96 & 814.73 & 4 & 1 & 16 & 8 & 160 \\
\hline $6 d$ & $(3-\mathrm{Cl}, 4-\mathrm{Br})$ & 4.08 & 905.31 & 4 & 1 & 16 & 32 & 172 \\
\hline $6 e$ & $(3,5-\mathrm{di}-\mathrm{Br})$ & 4.37 & 994.21 & 4 & 1 & 4 & 8 & 79 \\
\hline $6 f$ & $\left(3,5-\mathrm{di}-\mathrm{CF}_{3}\right)$ & 4.41 & 950.62 & 16 & 4 & 16 & 16 & 177 \\
\hline $6 \mathrm{~g}$ & $(4-\mathrm{tBu})$ & 4.47 & 790.85 & 4 & 1 & 4 & 8 & 145 \\
\hline $6 \mathrm{~h}$ & $(3,5-\mathrm{di}-\mathrm{tBu})$ & 6.29 & 903.06 & 1 & 0.25 & 2 & 4 & $<5$ \\
\hline $7 a$ & $\left(4-\mathrm{CF}_{3}\right)$ & 3.52 & 898.71 & 2 & 0.25 & 8 & 64 & $>449$ \\
\hline $7 \mathbf{b}$ & $(2-\mathrm{Nal})$ & 3.82 & 862.83 & 1 & 0.25 & 1 & 8 & 133 \\
\hline $7 \mathrm{c}$ & (4-F-1-Nal) & 3.96 & 898.81 & 1 & 0.25 & 1 & 4 & 90 \\
\hline $7 d$ & $(3-\mathrm{Cl}, 4-\mathrm{Br})$ & 4.08 & 989.39 & 0.5 & 0.25 & 2 & 8 & 77 \\
\hline $7 e$ & $(3,5-\mathrm{di}-\mathrm{Br})$ & 4.37 & 1078.30 & 1 & 0.25 & 2 & 4 & 62 \\
\hline $7 f$ & $\left(3,5-\mathrm{di}-\mathrm{CF}_{3}\right)$ & 4.41 & 1034.70 & 2 & 2 & 2 & 8 & 98 \\
\hline $7 \mathrm{~g}$ & $(4-\mathrm{tBu})$ & 4.47 & 874.93 & 1 & $<0.13$ & 2 & 4 & 77 \\
\hline $7 \mathrm{~h}$ & $(3,5-\mathrm{di}-\mathrm{tBu})$ & 6.29 & 987.14 & 1 & 0.25 & 4 & 4 & $<6$ \\
\hline \multicolumn{2}{|c|}{ Oxytetracycline } & 460.43 & 0.65 & 0.65 & 2.5 & 20 & & \\
\hline
\end{tabular}

${ }^{a}$ Bacterial reference strains: S. a-Staphylococcus aureus ATCC 9144, C. g-Corynebacterium glutamicum ATCC 13032, E. c-Escherichia coli ATCC 25922, and P. a-Pseudomonas aeruginosa PA01, DSM 19880 (ATCC 15692). ${ }^{b}$ Side chain Clog $P$ was calculated for a substituted toluene, 1-methyl-Nal, or 2-methyl-Nal (ChemBioDraw Ultra v13.0.2.3020). ${ }^{c}$ Molecular weight including 2 equiv of $\mathrm{CF}_{3} \mathrm{COO}^{-}$except for oxytetracycline.

Purification by $\mathrm{C}_{18} \mathrm{RP}$ flash chromatography gave the TFA salts of the target guanylated barbiturates $7 \mathbf{a}-\mathbf{h}$ with $>95 \%$ purity.

Structure-Activity Relationship Study against Reference Strains and Human Erythrocytes. Two series of amphipathic barbiturates were prepared, in which series 6 consisted of barbiturates with two cationic amino groups and series 7 encompassed barbiturates with two cationic guanidine groups (Figure 2). Note that an abbreviation for the lipophilic side chain substituents is included in parentheses to aid the discussion. The barbiturates were initially screened for antimicrobial activity against antibiotic susceptible Grampositive and Gram-negative reference strains (Table 1). Hemolytic activity was tested against human red blood cells (RBCs) as a measurement of toxicity.

Amine Barbiturates of Series 6 against Reference Strains. For the amine barbiturates in series $\mathbf{6}$, the minimum inhibitory concentration (MIC) values ranged from 0.25 to 64 $\mu \mathrm{g} / \mathrm{mL}$ against the Gram-positive strains Staphylococcus aureus and Corynebacterium glutamicum and MIC values from 2 to 128 $\mu \mathrm{g} / \mathrm{mL}$ against the Gram-negative bacteria E. coli and Pseudomonas aeruginosa (Table 1). Higher antimicrobial activity was thereby in general observed against Gram-positive bacteria than against Gram-negative bacteria, although the differences were marginal for the most potent amine barbiturates of series $\mathbf{6}$. Considering a membrane-disruptive mode of action (see below), the outer cell wall of Gramnegative bacteria may provide additional protection and thereby result in higher MIC values compared to Grampositive bacteria. For comparison, the four different eusynstyelamides isolated from Tegella $c f$. spitzbergensis display MIC values of $6.25-12.5 \mu \mathrm{g} / \mathrm{mL}$ against the Gram-positive bacteria S. aureus and C. glutamicum and $12.5-25 \mu \mathrm{g} / \mathrm{mL}$ against the Gram-negative bacteria E. coli and $P$. aeruginosa. ${ }^{5}$

The most potent amine barbiturate was $6 \mathbf{h}$ (3,5-di-tBu), which had two super-bulky lipophilic 3,5-di-tBu-benzylic side chains and displayed MIC values in the very low range of
$0.25-4 \mu \mathrm{g} / \mathrm{mL}$ against all Gram-positive and Gram-negative reference strains. The side chain $\operatorname{Clog} P$ of $\mathbf{6 h}$ (3,5-di-tBu) (Clog $P: 6.29$ ) was the highest calculated for all the lipophilic side chains included in the study (Table 1$)$. Derivative $6 \mathbf{h}(3,5-$ di-tBu) showed, however, unacceptable high hemolytic toxicity $\left(\mathrm{EC}_{50}:<5 \mu \mathrm{g} / \mathrm{mL}\right)$.

The two barbiturates $6 \mathrm{e}(3,5-\mathrm{di}-\mathrm{Br})$ and $6 \mathrm{~g}(4-\mathrm{tBu})$ were the second most potent derivatives displaying MIC values of $1-8$ $\mu \mathrm{g} / \mathrm{mL}$ against the bacterial reference strains and were both less hemolytic (6e EC $\mathrm{EC}_{50}: 79 \mu \mathrm{g} / \mathrm{mL}$ and $\left.6 \mathrm{~g} \mathrm{EC}_{50}: 145 \mu \mathrm{g} / \mathrm{mL}\right)$. These had smaller lipophilic side chains and implied a correlation between side chain size or calculated side chain Clog $P$ and antimicrobial activity.

The 3,5-di-substituted derivative 6 f $\left(3,5-\mathrm{di}-\mathrm{CF}_{3}\right)$ was less potent and displayed MIC values of $16 \mu \mathrm{g} / \mathrm{mL}$ against all strains except for the very susceptible strain $C$. glutamicum (MIC: $4 \mu \mathrm{g} / \mathrm{mL}$ ). The C. glutamicum strain is a valuable strain for identifying antimicrobial agents in screenings since it is so susceptible but is otherwise not of any medical importance. Its high susceptibility resulted in that none of the barbiturates from series 6 (nor series 7) displayed MIC values above $4 \mu \mathrm{g}$ / $\mathrm{mL}$ against $C$. glutamicum.

It is noteworthy that the calculated Clog $P$ of 6 e $(3,5-\mathrm{di}-\mathrm{Br})$ was lower than the calculated $C \log P$ of the less potent 6 f $(3,5-$ di- $\left.\mathrm{CF}_{3}\right)$, showing that not only the lipophilic effects of the side chains affected the antimicrobial potency but possibly also the size and electronic effects. With respect to electronic effects, a difference in electron distribution was observed both in ${ }^{13} \mathrm{C}$ NMR and when calculating the electron density of the bromine and trifluoromethyl substituents of $6 \mathrm{e}(3,5-\mathrm{di}-\mathrm{Br})$ and $\mathbf{6 f}(3,5-$ di- $\left.\mathrm{CF}_{3}\right)$. The electron distribution in the side chains of $6 \mathrm{e}(3,5-$ di-Br) and 6 f $\left(3,5-\right.$ di- $\left.\mathrm{CF}_{3}\right)$ was different hosting an overall more negative partial charge on the $\mathrm{CF}_{3}$ groups compared to the bromine substituents (results not shown). This may affect the electron distribution of the aromatic side chains and possibly affect the lipophilic side chains in their interaction with the bacterial membrane and especially related to 
Table 2. Antimicrobial Activity (MIC in $\mu \mathrm{g} / \mathrm{mL}$ ) of Selected Amine (Series 6) and Guanidine (Series 7 ) Barbiturates against 30 Multi-resistant Clinical Isolates ${ }^{a}$

\begin{tabular}{|c|c|c|c|c|c|c|c|c|c|c|c|c|c|c|c|c|c|}
\hline \multirow[b]{2}{*}{ Toxicity } & \multicolumn{8}{|c|}{ Amine barbiturates } & \multicolumn{8}{|c|}{ Guanidine barbiturates } & \\
\hline & $6 a$ & $6 \mathbf{b}$ & $6 \mathrm{c}$ & $6 \mathrm{~d}$ & $6 e$ & $6 f$ & $6 \mathrm{~g}$ & $6 \mathrm{~h}$ & $7 a$ & $7 \mathbf{b}$ & $7 \mathrm{c}$ & $7 \mathrm{~d}$ & $7 e$ & $7 \mathrm{f}$ & $7 \mathrm{~g}$ & $7 \mathbf{h}$ & \\
\hline $\mathrm{RBC} \mathrm{EC}_{50}$ & $>398$ & 250 & 160 & 172 & 79 & 177 & 145 & $<5$ & $>449$ & 133 & 90 & 77 & 62 & 98 & 77 & $<6$ & \\
\hline HepG2 IC 50 & 40 & 7 & 5 & 6 & 4 & 9 & 3 & 2 & 104 & 59 & 56 & 15 & 30 & 19 & 28 & 15 & \\
\hline MRC-5 IC 50 & 16 & 2 & 2 & 10 & 2 & 17 & 1 & 1 & 74 & 30 & 23 & 36 & 11 & 29 & 14 & 17 & \\
\hline Clinical isolates & & & & & & & & & & & & & & & & & $\mathrm{ESBL}^{-\mathrm{CARBA}}{ }^{b}$ \\
\hline S. aureus N315 & $>32$ & 8 & 8 & 8 & 4 & 16 & 8 & 2 & 4 & 8 & 2 & 2 & 2 & 2 & 2 & 4 & \\
\hline $\begin{array}{l}\text { S. aureus } \\
\text { NCTC } 10442\end{array}$ & $>32$ & 8 & 8 & 8 & 4 & 16 & 8 & 2 & 4 & 8 & 2 & 4 & 2 & 2 & 2 & 2 & \\
\hline $\begin{array}{l}\text { S. aureus strain } \\
85 / 2082\end{array}$ & $>32$ & 8 & 4 & 4 & 4 & 16 & 8 & 2 & 4 & 8 & 2 & 2 & 2 & 2 & 2 & 2 & \\
\hline S. aureus strain WIS & $>32$ & 8 & 8 & 8 & 4 & 16 & 8 & 2 & 4 & 8 & 2 & 2 & 2 & 2 & 2 & 2 & \\
\hline S. aureus IHT 99040 & $>32$ & 8 & 8 & 4 & 4 & 16 & 8 & 2 & 8 & 8 & 2 & 2 & 2 & 2 & 2 & 2 & \\
\hline E. faecium 50673722 & $>32$ & 16 & 8 & 16 & 4 & 8 & 8 & 2 & 32 & 16 & 4 & 4 & 4 & 2 & 2 & 2 & \\
\hline E. faecium 50901530 & $>32$ & 8 & 4 & 8 & 4 & 8 & 4 & 2 & 8 & 8 & 4 & 2 & 2 & 2 & 4 & 2 & \\
\hline E. faecium K36-18 & $>32$ & 16 & 8 & 16 & 8 & 16 & 8 & 2 & 32 & 16 & 4 & 4 & 4 & 4 & 2 & 2 & \\
\hline E. faecium 50758899 & $>32$ & 16 & 8 & 16 & 4 & 16 & 8 & 2 & $>32$ & 16 & 4 & 4 & 4 & 4 & 2 & 2 & \\
\hline $\begin{array}{l}\text { E. faecium } \\
\text { TUH50-22 }\end{array}$ & $>32$ & 8 & 4 & 4 & 4 & 8 & 8 & 2 & 32 & 8 & 4 & 2 & 2 & 2 & 2 & 2 & \\
\hline E. coli 50579417 & $>32$ & 16 & 16 & 16 & 8 & 16 & 8 & 4 & 32 & 16 & 8 & 4 & 4 & 8 & 4 & 16 & OXA-48 \\
\hline E. coli 50639799 & $>32$ & 16 & 16 & 16 & 8 & 16 & 8 & 4 & 16 & 8 & 4 & 4 & 4 & 4 & 4 & 8 & VIM-29 \\
\hline E. coli 50676002 & $>32$ & 16 & 16 & 16 & 8 & 16 & 4 & 8 & 32 & 8 & 4 & 4 & 4 & 4 & 4 & 16 & NDM-1 \\
\hline E. coli 50739822 & $>32$ & 16 & 16 & 16 & 8 & 16 & 8 & 4 & 32 & 8 & 8 & 4 & 4 & 8 & 4 & 8 & NDM-1 \\
\hline E. coli 50857972 & $>32$ & 16 & 16 & 16 & 8 & 8 & 4 & 4 & 16 & 8 & 4 & 4 & 4 & 4 & 4 & 8 & IMP-26 \\
\hline$P$. aeruginosa K34-7 & $>32$ & 32 & 32 & 32 & 16 & 32 & $>32$ & 8 & $>32$ & 32 & 16 & 16 & 8 & 16 & 16 & 16 & VIM-2 \\
\hline P. aeruginosa K34-73 & $>32$ & 32 & 32 & 32 & 16 & 32 & $>32$ & 16 & $>32$ & 32 & 8 & 8 & 8 & 16 & 8 & 8 & VIM-4 \\
\hline P. aeruginosa K44-24 & $>32$ & $>32$ & 32 & 32 & 16 & 32 & $>32$ & 8 & $>32$ & 32 & 16 & 16 & 8 & 16 & 16 & 16 & IMP-14 \\
\hline $\begin{array}{l}\text { P. aeruginosa } \\
50692172\end{array}$ & $>32$ & 32 & 16 & 32 & 16 & 32 & $>32$ & 8 & $>32$ & 32 & 16 & 32 & 8 & 16 & 16 & 16 & NDM-1 \\
\hline $\begin{array}{l}P . \text { aeruginosa } \\
50692520\end{array}$ & $>32$ & 32 & 16 & 32 & 16 & 32 & $>32$ & 8 & $>32$ & 32 & 16 & 16 & 16 & 16 & 16 & 16 & VIM \\
\hline $\begin{array}{l}\text { K. pneumoniae } \\
\text { K47-25 }\end{array}$ & $>32$ & $>32$ & $>32$ & 32 & 16 & $>32$ & $>32$ & 16 & $>32$ & 16 & 8 & 4 & 4 & 16 & 4 & 16 & KPC-2 \\
\hline $\begin{array}{l}\text { K. pneumoniae } \\
\text { K66-45 }\end{array}$ & $>32$ & $>32$ & 32 & 32 & 16 & 32 & 32 & 8 & $>32$ & 16 & 4 & 8 & 4 & 16 & 4 & 8 & NDM-1 \\
\hline $\begin{array}{c}\text { K. pneumoniae } \\
50531633^{c}\end{array}$ & $>32$ & 32 & 16 & 16 & 8 & 32 & 16 & 8 & $>32$ & 16 & 8 & 4 & 4 & 16 & 4 & 16 & NDM-1+OXA-181 \\
\hline $\begin{array}{l}\text { K. pneumoniae } \\
50625602\end{array}$ & $>32$ & $>32$ & 32 & 32 & 16 & 32 & 16 & 8 & $>32$ & 16 & 16 & 4 & 4 & 8 & 4 & 16 & OXA-245 \\
\hline $\begin{array}{l}\text { K. pneumoniae } \\
50667959\end{array}$ & $>32$ & $>32$ & 32 & 32 & 16 & 32 & 32 & 8 & $>32$ & 16 & 4 & 8 & 4 & 16 & 16 & 8 & VIM-1 \\
\hline A. baumannii K12-21 & $>32$ & 32 & 32 & 32 & 16 & 16 & 16 & 4 & $>32$ & 32 & 8 & 8 & 4 & 16 & 4 & 4 & OXA-58 \\
\hline A. baumannii K44-35 & $>32$ & 32 & 32 & 32 & 16 & 32 & 32 & 4 & $>32$ & 32 & 8 & 8 & 4 & 16 & 8 & 4 & OXA-23 \\
\hline A. baumannii K47-42 & $>32$ & 32 & 32 & 32 & 16 & 32 & 16 & 4 & $>32$ & 32 & 8 & 8 & 4 & 16 & 8 & 4 & OXA-23 \\
\hline A. baumannii K55-13 & $>32$ & 32 & 32 & 32 & 16 & 32 & 16 & 4 & $>32$ & 32 & 8 & 8 & 8 & 16 & 8 & 4 & OXA-24 \\
\hline $\begin{array}{l}\text { A. baumannii } \\
\text { K63-58 }\end{array}$ & $>32$ & 16 & 16 & 32 & 16 & 32 & 16 & 4 & $>32$ & 32 & 8 & 8 & 4 & 16 & 4 & 4 & OXA-23 \\
\hline
\end{tabular}

${ }^{{ }^{a}}$ Toxicity is displayed as the hemolytic activity against human $\mathrm{RBCs}\left(\mathrm{EC}_{50}\right.$ in $\mu \mathrm{g} / \mathrm{mL}$ from Table 1$)$ and cytotoxicity against HepG2 and MRC-5 cells $\left(\mathrm{IC}_{50}\right.$ in $\left.\mu \mathrm{g} / \mathrm{mL}\right) .{ }^{b}$ ESBL-CARBA: extended spectrum $\beta$-lactamase-carbapenemase producing isolates. OXA, oxacillinase; VIM, verona integron-encoded metallo- $\beta$-lactamase; NDM, New Delhi metallo- $\beta$-lactamase; IMP, imipenem-type carbapenemase; and KPC, K. pneumoniae carbapenemase. ${ }^{c}$ Clinical isolates resistant to the antibiotic colistin.

localization in the water-lipid interface region of the membrane. This may also explain why 6 f $\left(3,5-\mathrm{di}-\mathrm{CF}_{3}\right)$ displayed much lower hemolytic activity $\left(\mathrm{EC}_{50}: 177 \mu \mathrm{g} / \mathrm{mL}\right)$ than 6e $(3,5$-di-Br $)\left(\mathrm{EC}_{50}: 79 \mu \mathrm{g} / \mathrm{mL}\right)$.

The 3,4-disubstituted derivative $\mathbf{6 d}$ (3-Cl, 4-Br) displayed high antimicrobial activity against the Gram-positive reference strains (MIC: $1-4 \mu \mathrm{g} / \mathrm{mL}$ ) but was clearly less potent than the previous derivatives against the Gram-negative reference strains (MIC: 16-32 $\mu \mathrm{g} / \mathrm{mL})$. Derivative 6d (3-Cl, 4-Br) also showed very low hemolytic activity $\left(\mathrm{EC}_{50}: 172 \mu \mathrm{g} / \mathrm{mL}\right)$.

The Nal-derivatives $\mathbf{6 b}(2-\mathrm{Nal})$ and $6 \mathbf{c}(4-\mathrm{F}-1-\mathrm{Nal})$ showed comparable antimicrobial activities, that is, MIC: $1-8 \mu \mathrm{g} / \mathrm{mL}$ against the Gram-positive reference strains and MIC: 8-16 $\mu \mathrm{g} / \mathrm{mL}$ against the Gram-negative strains. These Nal derivatives differed slightly in calculated side chain lipophilicity [6b (2-Nal): $\mathrm{Clog} P$ 3.82, and 6c (4-F-1-Nal): Clog P 3.96]. An important prospect with these $\mathrm{Nal}$ derivatives is possible tuning of pharmacokinetic properties related to phase I hepatic oxidations in vivo. Our previous studies on small $\beta^{2,2}$-amino acid-based AMP peptidomimetics have shown that 2-Nal side chains can be extensively oxidized by liver microsomes, which is a model system used to assess the potential hepatic phase I metabolism. ${ }^{17,28}$ This oxidation is however reduced by having electron-withdrawing aromatic fluorine substituents such as in 
6c (4-F-1-Nal). Aromatic fluorine substituents are often used as "metabolic blockers" in drugs to improve the pharmacokinetic properties. ${ }^{29}$ Both Nal-derivatives $6 \mathbf{b}(2-\mathrm{Nal})$ and $6 \mathbf{c}$ (4F-1-Nal) showed very low hemolytic activity. When comparing the hemolytic results in detail, the somewhat less lipophilic derivative $\mathbf{6 b}(2-\mathrm{Nal})$ displayed lower hemolytic activity $\left(\mathrm{EC}_{50}\right.$ : $250 \mu \mathrm{g} / \mathrm{mL})$ than $6 \mathrm{c}(4-\mathrm{F}-1-\mathrm{Nal})\left(\mathrm{EC}_{50}: 160 \mu \mathrm{g} / \mathrm{mL}\right)$. In this case, a small modification by having an aromatic fluorinesubstituent seemingly had an impact on RBC toxicity.

A surprisingly low antimicrobial activity was observed for the least lipophilic derivative 6a $\left(4-\mathrm{CF}_{3}\right)$, which only had acceptable antimicrobial activity against $C$. glutamicum but very low potency against the remaining reference strains (MIC: 64-128 $\mu \mathrm{g} / \mathrm{mL})$. Derivative 6a $\left(4-\mathrm{CF}_{3}\right)$ was also all together non-hemolytic within the concentration range tested $\left(\mathrm{EC}_{50}\right.$ : $>398 \mu \mathrm{g} / \mathrm{mL}$ ).

Guanidine Barbiturates of Series 7 against the Reference Strains. Guanylation of the amine barbiturates in series 6 resulted in a striking increase in the antimicrobial activity of the resulting guanidine barbiturates in series 7 (Table 1). The highly potent guanylated barbiturates of series 7 displayed a narrow range in the MIC values of $<0.13-2 \mu \mathrm{g} /$ $\mathrm{mL}$ against the Gram-positive strains $S$. aureus and $C$. glutamicum and MIC $1-8 \mu \mathrm{g} / \mathrm{mL}$ against the Gram-negative bacteria $E$. coli and $P$. aeruginosa. One exception lacking increased potency against $P$. aeruginosa was $7 \mathbf{a}\left(4-\mathrm{CF}_{3}\right)(\mathrm{MIC}$ : $64 \mu \mathrm{g} / \mathrm{mL}$ ), which was the smallest guanidine derivative (in volume) and least lipophilic derivative.

Overall, the results for the guanidine series 7 followed the structural considerations discussed for the antimicrobial activity of the amine barbiturates in series 6. Highest broadspectrum antimicrobial activity (MIC $\leq 4 \mu \mathrm{g} / \mathrm{mL}$ ) was displayed by $7 \mathrm{c}$ (4-F-1-Nal), 7e (3,5-di-Br), 7g (4-tBu), and 7h $(3,5-\mathrm{di}-\mathrm{tBu})$. The guanylated barbiturates $7 \mathbf{b}(2-\mathrm{Nal}), 7 \mathrm{~d}$ (3-Cl, 4-Br), and 7f (3,5-di- $\left.\mathrm{CF}_{3}\right)$ showed the same high potency against the Gram-positive reference strains and $E$. coli but a little lower activity against $P$. aeruginosa. Altogether, the differences in MIC values were small. The largest improvements in the antimicrobial activity following guanylation was observed for $7 \mathbf{a}\left(4-\mathrm{CF}_{3}\right)$ and $7 \mathbf{f}\left(3,5-\mathrm{di}-\mathrm{CF}_{3}\right)$ against the Grampositive reference strains and $E$. coli.

The guanylated barbiturates of series 7 were in comparison more hemolytic than the amine barbiturates in series 6 , and only derivatives, $7 \mathbf{a}\left(4-\mathrm{CF}_{3}\right)$ and $7 \mathbf{b}(2-\mathrm{Nal})$, displayed hemolytic toxicity with $\mathrm{EC}_{50}$ values above $100 \mu \mathrm{g} / \mathrm{mL}$. The guanylated barbiturates 7c (4-F-1-Nal), 7d (3-Cl, 4-Br), 7e (3,5-di-Br), $7 f$ (3,5-di- $\left.\mathrm{CF}_{3}\right)$, and $7 \mathrm{~g}(4-\mathrm{tBu})$ displayed hemolytic toxicity in the range $\mathrm{EC}_{50}: 62-98 \mu \mathrm{g} / \mathrm{mL}$, whereas the super-bulky barbiturate $7 \mathbf{h}(3,5-\mathrm{di}-\mathrm{tBu})$ was highly hemolytic $\left(\mathrm{EC}_{50}:<6 \mu \mathrm{g} / \mathrm{mL}\right)$.

The general increase in the hemolytic activity following guanylation can be a result of the larger guanidine group forming more intricate electrostatic and hydrogen-bonding interactions than a primary amine group and thereby interact with both anionic and zwitterionic phospholipids (PLs). As we and others have reported, there is little consistency, and both increase and reduction of RBC toxicity is observed when amine groups are interchanged by guanidine groups. ${ }^{17,30-34}$

Antimicrobial Activity against 30 Multi-resistant Clinical Isolates. The amine and guanidine barbiturates were screened against a panel of 30 multi-resistant clinical isolates of Gram-positive and Gram-negative bacteria (Table 2). These isolates represented different resistance mechanisms, in which the Gram-positive isolates were methicillin-resistant $S$. aureus (MRSA) and vancomycin-resistant Enterococcus faecium (VRE), and the Gram-negative isolates included multi-resistant E. coli, P. aeruginosa, Klebsiella pneumoniae, and Acinetobacter baumannii with extended spectrum $\beta$-lactamase-carbapenemase (ESBL-CARBA) production. Three strains were also resistant to the last resort antibiotic colistin. Cytotoxicity was also determined against human hepatocyte carcinoma cells (HepG2) and human lung fibroblast cells (MRC-5).

Antimicrobial activity against the multi-resistant clinical isolates was high with MIC values as low as $2-4 \mu \mathrm{g} / \mathrm{mL}$ for the most potent barbiturates, thereby following the same tendencies as against the antibiotic susceptible reference strains. As opposed to RBC toxicity, the guanidine barbiturates of series 7 were less cytotoxic against human HepG2 and MRC-5 cells compared to the amine barbiturates of series 6 (Table 2). The interplay between the two different cationic groups and the various lipophilic side chains thereby influenced the antimicrobial potency, hemolytic toxicity, and human cell cytotoxicity differently.

For the amine barbiturates of series 6, highest antimicrobial potencies (MIC: $2-16 \mu \mathrm{g} / \mathrm{mL}$ ) were achieved against the Gram-positive multi-resistant clinical isolates of $S$. aureus and E. faecium and the Gram-negative isolates of E. coli. The overall most potent amine barbiturate of series 6 was $6 \mathbf{h}(3,5-\mathrm{di}-\mathrm{tBu})$, closely followed by $6 \mathrm{e}(3,5-\mathrm{di}-\mathrm{Br})$. These amine derivatives showed high potency also against the clinical challenging isolates of $P$. aeruginosa, $K$. pneumonia, and $A$. baumannii. The high cytotoxicity against human HepG2 and MRC-5 cells $\left(\mathrm{IC}_{50}: 1-17 \mu \mathrm{g} / \mathrm{mL}\right.$ ) displayed by the active amine barbiturates of series 6 was unsatisfactory.

The guanidine series 7 represented a major increase in the antimicrobial activity against the Gram-negative multi-resistant clinical isolates compared to the amine series 6 . The guanidine barbiturates of series 7 were also less cytotoxic against human HepG2 and MRC-5 cells compared to the amine barbiturates of series 6 . The most potent broad-spectrum guanidine barbiturates were $7 \mathrm{c}(4-\mathrm{F}-1-\mathrm{Nal}), 7 \mathbf{d}(3-\mathrm{Cl}, 4-\mathrm{Br}), 7 \mathrm{e}(3,5-\mathrm{di}-$ $\mathrm{Br}), \quad 7 \mathbf{f}\left(3,5-\mathrm{di}-\mathrm{CF}_{3}\right), 7 \mathbf{g}(4-\mathrm{tBu})$, and $7 \mathbf{h}(3,5-\mathrm{di}-\mathrm{tBu})$ displaying MIC values of $2-16 \mu \mathrm{g} / \mathrm{mL}$ (Table 2). The cytotoxicity of these guanidine barbiturates against human HepG2 and MRC-5 cells was in the range $\mathrm{IC}_{50}: 11-59 \mu \mathrm{g} / \mathrm{mL}$ and thereby less cytotoxic than the amine barbiturates of series 6. The broad-spectrum guanidine barbiturate 7 e (3,5-di-Br) showed overall highest antimicrobial potency against all multiresistant clinical isolates tested and became the selected compound for the in vivo pilot study described below.

It should also be noted that the least lipophilic guanidine barbiturate $7 \mathbf{a}\left(4-\mathrm{CF}_{3}\right)$ may be a promising compound when considering specifically MRSA infections by its high potency (MIC: $4-8 \mu \mathrm{g} / \mathrm{mL}$ ) against the clinical multi-resistant $S$. aureus isolates, low cytotoxicity against human HepG2 ( $\mathrm{IC}_{50}$ : $104 \mu \mathrm{g} / \mathrm{mL}$ ) and MRC-5 cells $\left(\mathrm{IC}_{50}: 74 \mu \mathrm{g} / \mathrm{mL}\right.$ ), and by being all together non-hemolytic $\left(\mathrm{EC}_{50}:>449 \mu \mathrm{g} / \mathrm{mL}\right.$, Table 2$)$.

All the investigated amphipathic barbiturates displayed antimicrobial activity against the three colistin-resistant clinical isolates K. pneumoniae K47-25, K. pneumoniae 50531633, and A. baumannii K63-58 in the same range as against the colistinsusceptible clinical isolates. The mechanism of resistance of these clinical isolates is thought to involve altered lipopolysaccharide (LPS) outer cell wall composition and charge, changes that affect the mechanism of action of the last-resort cationic antibiotic colistin (pers. commun. prof $\varnothing$. Samuelsen). 
A)

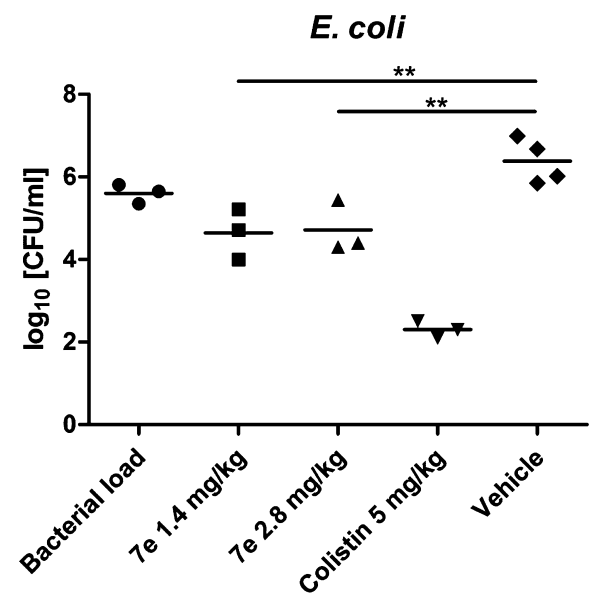

B)

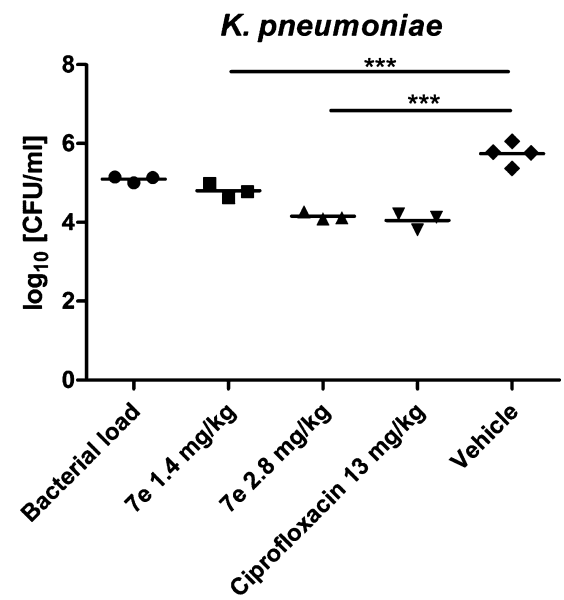

Figure 3. Reduction in the CFU of (A) E. coli (EC106-09) and (B) K. pneumoniae (KP3010) after i.p. treatment with $1.4 \mathrm{mg} / \mathrm{kg}$ (1 h postinfection) and $2.8 \mathrm{mg} / \mathrm{kg}(1,4 \mathrm{mg} / \mathrm{kg} 1 \mathrm{~h}+3 \mathrm{~h}$ post-infection) of $7 \mathrm{e}(3,5-\mathrm{di}-\mathrm{Br})$ compared to single i.p. treatment with (A) colistin (positive control, $5 \mathrm{mg} / \mathrm{kg} 1 \mathrm{~h}$ post-infection) and (B) ciprofloxacin (positive control, $13 \mathrm{mg} / \mathrm{kg}, 1 \mathrm{~h}$ post-infection) and vehicle (negative control, $1 \mathrm{~h}$ postinfection) was observed. The symbols $(\boldsymbol{\Lambda}, \boldsymbol{\nabla}, \boldsymbol{\nabla}$, and $\mathbf{\square})$ represent the individual mice in the experiment. The horizontal line represents the mean value of CFU counted for the parallels for the same experiment. Asterisks indicate the significant difference between vehicle control and treatment with $7 \mathrm{e}$ (Dunnet's test; $* * p<0.01$ and $* * * p<0.001$ ).

A

$6 e$

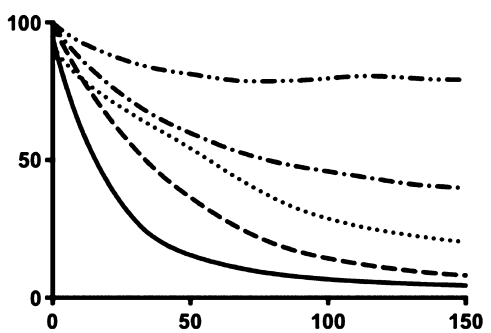

$7 e$

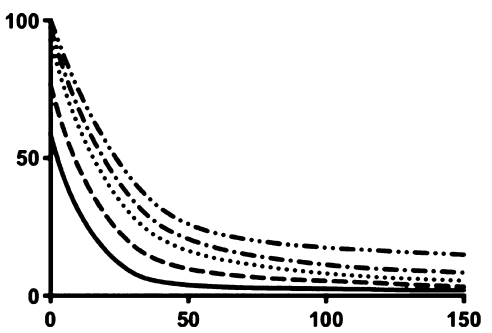

CHX

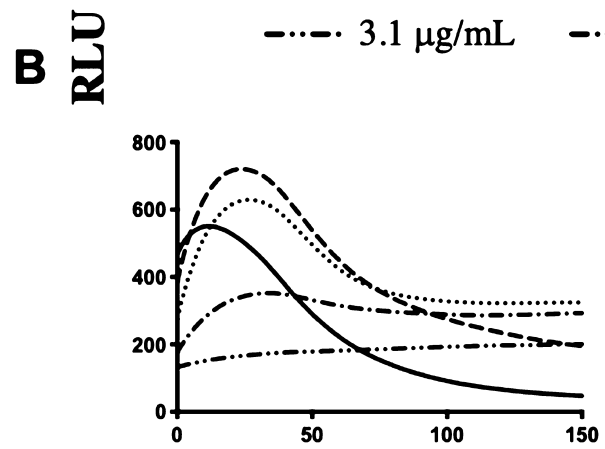

$6.2 \mu \mathrm{g} / \mathrm{mL}$

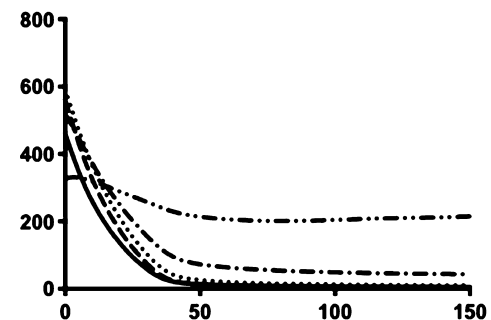

$12.5 \mu \mathrm{g} / \mathrm{mL}$

100

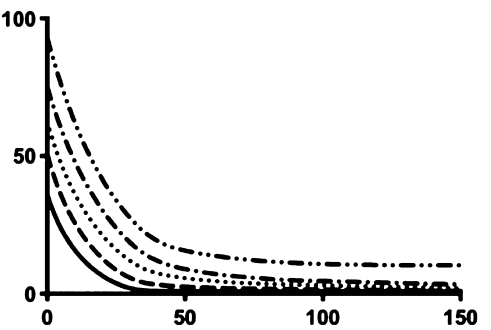

$25 \mu \mathrm{g} / \mathrm{mL}$

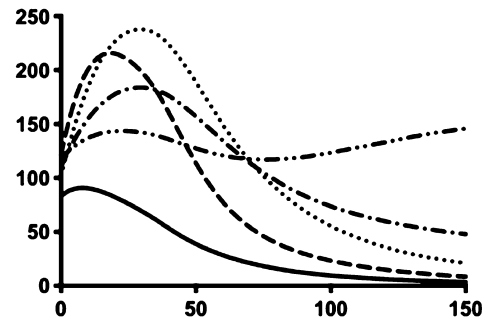

Time (sec)

Figure 4. Comparison of the effects of 6 e (3,5-di-Br), 7e (3,5-di-Br), and CHX on the kinetics of (A) viability and (B) membrane integrity in B. subtilis. Light emission normalized to an untreated water control (negative control) is plotted as relative light units (RLUs) over time (seconds) with untreated luminescence set to $100 \mathrm{RLU}$. After addition of the bacterial cell suspension (with $1 \mathrm{mM}$ D-luciferin for the membrane integrity assay) to the analytes in each well, the light emission was measured each second for $150 \mathrm{~s}$. Each line represents the kinetics of 150 subsequent data points of the analyte concentration. Each analysis was repeated at least three times independently. The figure shows a representative data set.

The altered LPS structure seemed not to have any major impact on the binding and activity of the most potent amphipathic barbiturates.

In Vivo Efficacy of $7 \mathrm{e}(3,5-\mathrm{di}-\mathrm{Br})$ in a Murine Neutropenic Peritonitis Model. The overall most potent guanidine barbiturate $7 \mathrm{e}(3,5-\mathrm{di}-\mathrm{Br})$ was investigated in vivo using an established murine peritonitis model at Statens Serum Institut (SSI, Denmark). ${ }^{35}$ Our aim was to determine the efficacy of $7 \mathbf{e}(3,5$-di-Br) in mice infected with clinical isolates of E. coli (EC106-09) and K. pneumoniae (KP3010). Initially, the MIC of 7 e $(3,5-\mathrm{di}-\mathrm{Br})$ was determined to be $4 \mu \mathrm{g} / \mathrm{mL}$ against both strains, which was in coherence with our previous 
A

$6 e$

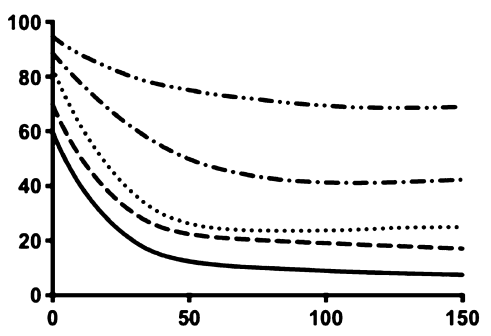

$7 e$

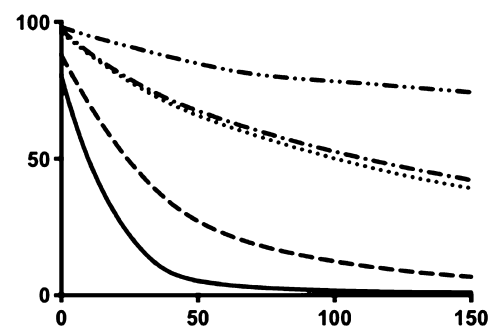

CHX

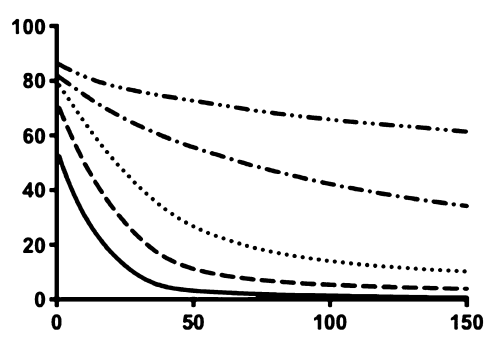

B $\stackrel{9}{a}$

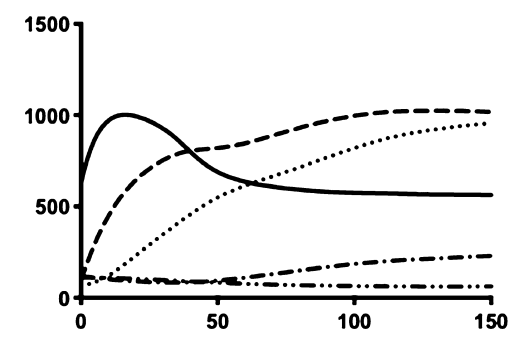

$-6.2 \mu \mathrm{g} / \mathrm{mL}$

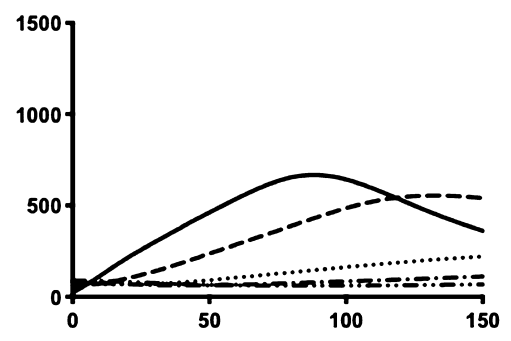

Time (sec)

$12.5 \mu \mathrm{g} / \mathrm{mL}$
---. $25 \mu \mathrm{g} / \mathrm{mL}$

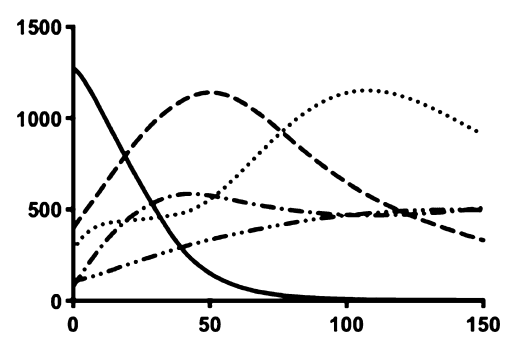

Figure 5. Comparison of the effects of 6 e (3,5-di-Br), 7e (3,5-di-Br), and CHX on the kinetics of (A) viability and (B) membrane integrity in E. coli. Light emission normalized to the untreated water control (negative control) is plotted as RLU over time (seconds) with untreated luminescence set to $100 \mathrm{RLU}$. After addition of the bacterial cell suspension (with $1 \mathrm{mM}$ D-luciferin for the membrane assay) to the analytes in each well, the light emission was measured each second for $150 \mathrm{~s}$. Each line represents the kinetics of 150 subsequent data points of the analyte concentration. Each analysis was repeated at least three times independently. The figure shows a representative data set.

screening results. A maximal tolerated dose (MTD) was determined prior to evaluation of in vivo efficacy. In brief, the MTD was determined by intraperitoneal (i.p.) injection of escalating doses of derivative $7 \mathbf{e}(3,5-\mathrm{di}-\mathrm{Br})$. Derivative $7 \mathbf{e}$ (3,5-di-Br) was well tolerated up to $2.8 \mathrm{mg} / \mathrm{kg}$ after i.p. injection with no or mild clinical signs of discomfort. At 3.6 $\mathrm{mg} / \mathrm{kg}$, moderate signs of discomfort were observed, but the mice recovered within a few hours. The MTD was determined to be $7 \mathrm{mg} / \mathrm{kg}$.

In our vehicle controls, a log colony-forming unit per $\mathrm{mL}$ $(\mathrm{CFU} / \mathrm{mL})$ of 6.4 was determined for E. coli, indicating a 0.8 $\log$ CFU increase at the end of the experiment. A log CFU $/ \mathrm{mL}$ of 5.7 was determined for K. pneumoniae corresponding to an approximately $0.6 \mathrm{CFU} / \mathrm{mL}$ increase at the end of the experiment. In contrast, treatment with $7 \mathrm{e}(3,5-\mathrm{di}-\mathrm{Br})$ caused a $1.7-\log (98 \%)$ reduction of the bacterial loads of E. coli already at a concentration of $1.4 \mathrm{mg} / \mathrm{mL}$ (Figure $3 \mathrm{~A}$ ). Treatment with $1.4 \mathrm{mg} / \mathrm{kg}$ of $7 \mathrm{e}(3,5-\mathrm{di}-\mathrm{Br})$ against $\mathrm{K}$. pneumoniae resulted in a $1 \log \mathrm{CFU} / \mathrm{mL}$ reduction (90\%) compared to treatment with vehicle (Figure 3B). A repeated injection after $3 \mathrm{~h}$ with $7 \mathrm{e}(3,5-\mathrm{di}-\mathrm{Br})$ resulted in a $1.6 \mathrm{log}$ $\mathrm{CFU} / \mathrm{mL}$ (97\%) reduction of the bacterial load. Despite limitations regarding the MTD, our results demonstrated that $7 \mathbf{e}(3,5-\mathrm{di}-\mathrm{Br})$ could significantly reduce the number of viable bacterial cells in this in vivo model. We can conclude that the complex environment of the peritoneal cavity and the peritoneal fluid did not lead to a rapid inactivation of $7 \mathbf{e}$ (3,5-di-Br). However, at this point, we can only speculate about the time range $7 \mathbf{e}(3,5-\mathrm{di}-\mathrm{Br})$ is present in sufficient concentrations for effective bacterial killing. Pharmacokinetic studies as well as different routes of administration have to be undertaken in order to fully reveal the potential of this type of compound in vivo.

Mode of Action Studies. The amphipathic amine barbiturate 6 e (3,5-di-Br) and guanidine barbiturate 7e (3,5di-Br) were compared in a mode of action study using two luciferase-based biosensor assays in Bacillus subtilis 168 and E. coli HB101 (Figures 4 and 5). ${ }^{36,37}$ The two different biosensor systems evaluate the effects on bacterial viability and membrane integrity, respectively, which are closely linked functionalities in bacterial cells (see the Supporting Information; Section S9 for detailed information regarding the assays). The bacteriolytic agent chlorhexidine (CHX), known for its membrane-disruptive properties, was analyzed for comparison. $^{38}$

The overall results demonstrated a strong and immediate membrane disrupting activity for both compounds. A more rapid membranolytic effect was observed against the Grampositive B. subtilis compared to Gram-negative E. coli. We also observed the differences in the rate of membrane lysis related to the test concentrations, in which concentrations higher than the MIC value led to a more rapid lysis, that is, a concentration-dependent killing effect.

The observed effects in the viability assay corresponded well with the respective MICs [6e (3,5-di-Br): $6.3 \mu \mathrm{g} / \mathrm{mL}$ and $7 \mathbf{e}$ (3,5-di-Br): $3.1 \mu \mathrm{g} / \mathrm{mL}$ against both $B$. subtilis and $E$. coli biosensor strains], in spite of an initial 1000-fold higher concentration of bacteria in the inoculum compared to the MIC assay. The decrease in light emission was rapid, dosedependent, and similar to the $\mathrm{CHX}$ control, suggesting a 


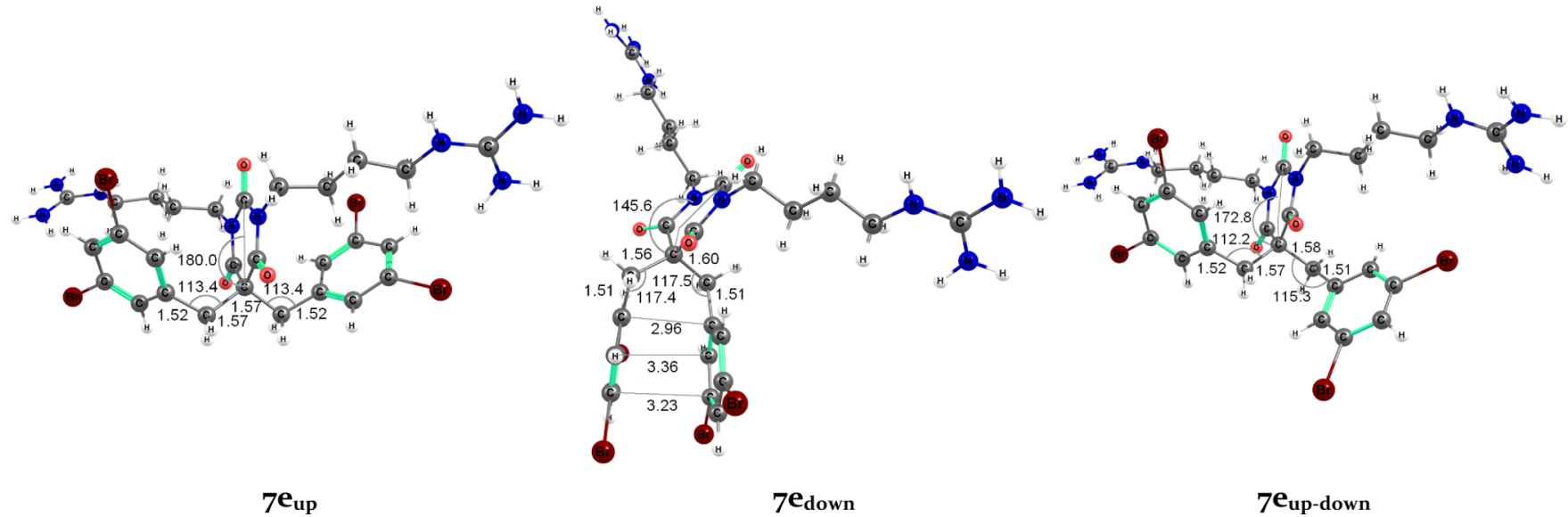

Figure 6. Optimized geometries from DFT calculations of $7 \mathbf{e}_{\text {up }}$ (left, also described as the W-shaped conformation), $7 \mathbf{e}_{\text {down }}$ (middle), and $7 \mathbf{e}_{\text {up-down }}$ (right). The bond distances are reported in $\AA$ and the bond angles are given in degrees.

membrane-related mode of action against both strains (Figures $4 \mathrm{~A}$ and $5 \mathrm{~A})$. In order to confirm that the rapid decrease in bacterial viability was due to membrane damage, the membrane integrity assay was performed. Also, in this assay, a dose-dependent effect was observed against both strains (Figures 4B and 5B). The effects (rapid peak emission due to the influx of D-luciferin into the cells) were for the most part coinciding with the respective MIC values, indicating that membrane damage was indeed a major effect. The well-by-well measurements allowed for catching the actual light peaks, apart from measurements with $7 \mathrm{e}(3,5-\mathrm{di}-\mathrm{Br})$ in $\mathrm{B}$. subtilis, which seemed to act substantially faster than 6 e (3,5-di-Br) and CHX and therefore only showed a decrease in light emission from a level substantially higher than the control (Figure 4B).

When comparing the results obtained from the viability assay (Figure $4 \mathrm{~A}$ ) and the membrane integrity assay (Figure $4 \mathrm{~B})$ in B. subtilis for compounds $6 \mathrm{e}$ (3,5-di-Br), 7e (3,5-di-Br), and $\mathrm{CHX}$, the patterns appeared somewhat similar, indicating a rapid membranolytic activity for all compounds. However, in the membrane integrity assay in B. subtilis, we were not able to determine a peak in light emission for any concentration above MIC for 7e (3,5-di-Br) (Figure 4B). Light emission declined immediately, indicating that peak emission already had occurred before the first measurement, that is, within $2 \mathrm{~s}$ after analyte addition. At MIC $(3.1 \mu \mathrm{g} / \mathrm{mL})$, a small peak in light emission was observed after approximately $5 \mathrm{~s}$, but the emission did neither decrease nor increase substantially within the measurement window. Altogether, the effect of 7e (3,5-di$\mathrm{Br}$ ) on $\mathrm{B}$. subtilis shown in the viability assay seemed to be immediate (Figure 4A) and corresponded to the membranolytic effect shown in the membrane integrity assay (Figure 4B).

In E. coli, the observed overall picture was somewhat different. A rise or peak of light emission in the membrane integrity assay for $6 \mathbf{e}(3,5-\mathrm{di}-\mathrm{Br})$ coincided with an immediate decrease of light emission in the viability assay (similar to the results in B. subtilis) (Figure 5). However, an emission peak was not reached for the lowest $(1-4 \times \mathrm{MIC})$ concentrations of $7 \mathrm{e}(3,5$-di-Br $)$ within the $150 \mathrm{~s}$ test window in the membrane integrity assay (Figure 5B). On the other hand, the concentration-dependent reduction in viability observed with the guanidine barbiturate $7 \mathrm{e}(3,5-\mathrm{di}-\mathrm{Br})$ resembled the results of the guanidine-containing $\mathrm{CHX}$ (Figure 5A), but the decrease in viability was substantially slower than for similar concentrations in B. subtilis (Figure 4B). In general, the membrane integrity effects of all tested compounds seemed to occur at a slightly slower rate in the Gram-negative E. coli compared to the Gram-positive B. subtilis. It is tempting to speculate that especially for $7 \mathbf{e}(3,5-\mathrm{di}-\mathrm{Br})$, the outer membrane of $E$. coli acted as a barrier, causing a delayed action in the membrane integrity assay. This would however not explain the presence of light production at a time point where the viability assay emits almost no light at all and accordingly indicates complete metabolic shutdown. This effect, even though less pronounced, was also observable for 6e (3,5-di-Br) and the CHX control. Although ATP is necessary for replenishment of the fatty aldehyde pool, this might indicate that reduction equivalents were the limiting factor for light emission of the viability sensor assay and that ATP under these conditions was not a limiting factor after treatment with $6 \mathbf{e}$ (3,5-di-Br), and especially, 7e (3,5-di-Br) until after the measurement window ended. Alternatively, there were different subpopulations of bacterial cells present, with different susceptibility to the analytes, resulting in an average light emission, which does not represent any of the subpopulations.

While the main mode of action against $B$. subtilis for both $6 \mathrm{e}$ (3,5-di-Br) and $7 \mathbf{e}(3,5-\mathrm{di}-\mathrm{Br})$ seemed to be disruption of membrane integrity, our results did not exclude the possibility that especially $7 \mathbf{e}(3,5$-di-Br $)$ might have additional targets than the bacterial cytoplasmic membrane. Further work is needed to elucidate if $7 \mathbf{e}(3,5-\mathrm{di}-\mathrm{Br})$ possibly targets other components of the cell and if there is a dual mode of action.

Conformational Analysis and Membrane Interaction Simulations. To gain insights into the interactions of the amphipathic barbiturates with a PL membrane surface, we determined the most stable conformations of the barbiturates, followed by a membrane interaction simulation. Density functional theory (DFT)-based geometry optimizations of amine 6 e (3,5-di-Br) and guanidine 7 e (3,5-di-Br) gave similar distortions and energy differences and indicated three lowenergy conformations mainly differing in the orientation of the benzylic side chains (Figure 6). In the up $\left(7 \mathbf{e}_{\text {up }}\right)$, down $\left(7 \mathbf{e}_{\text {down }}\right)$, and up-down $\left(7 \mathbf{e}_{\text {up-down }}\right)$ conformations, the benzylic side chains were either directed upward in a $\mathrm{W}$ shape, downward, or having one side chain pointing up and the other pointing down. The $7 \mathbf{e}_{\mathrm{up}}$ conformation was lowest in energy, whereas $7 \mathbf{e}_{\text {up-down }}$ and $7 \mathbf{e}_{\text {down }}$ were 4.9 and $9.8 \mathrm{kcal} /$ mol higher in energy, respectively (see Supporting Information 

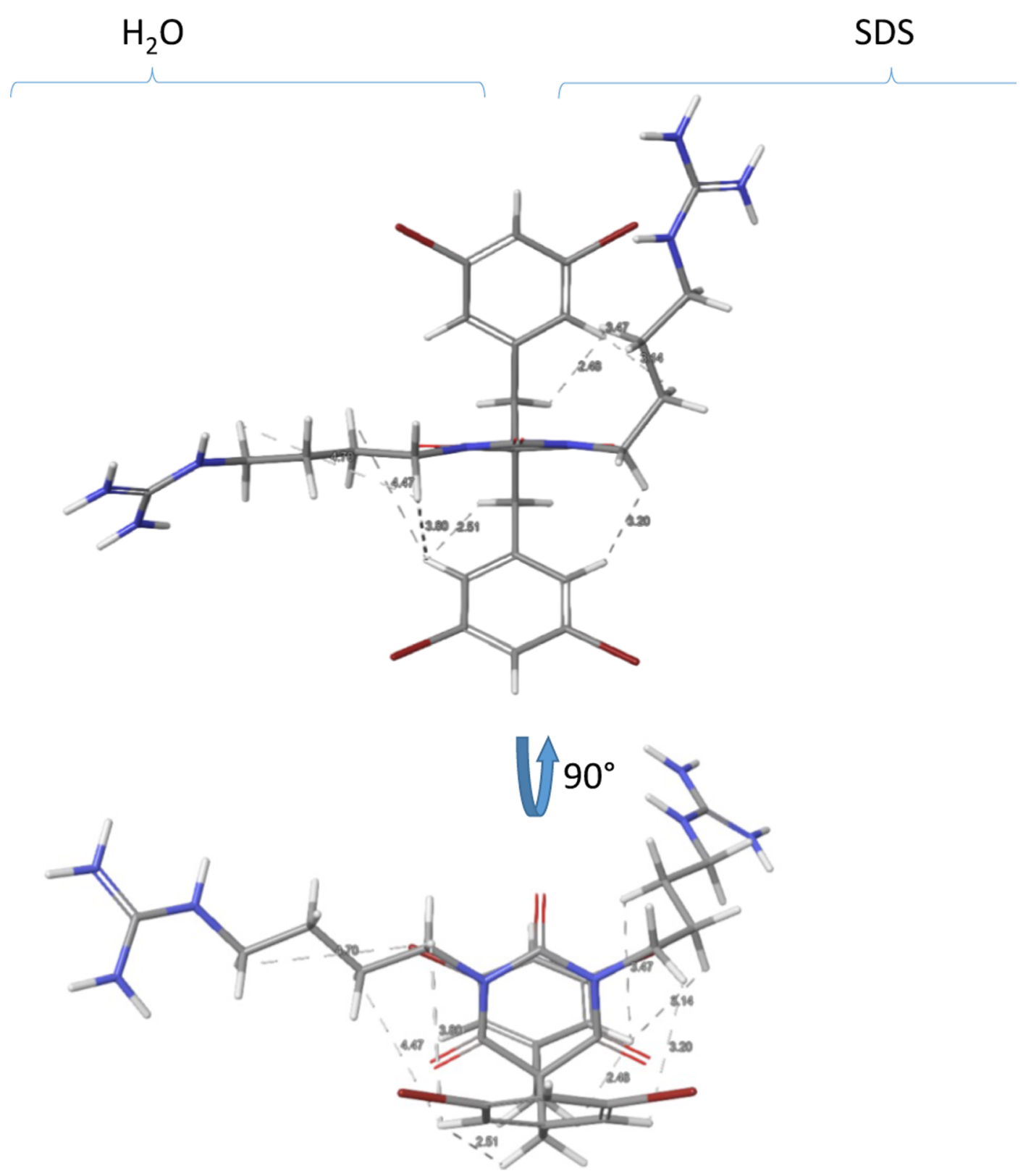

Figure 7. Schematic visualization of the observed ROESY correlations for 7e (3,5-di-Br) in water (left side) and in SDS (right side) using sculpted structures.

Section S10 for more details of the conformational analysis). An X-ray structure of $7 \mathbf{b}(2-\mathrm{Nal})$ supported the low energy conformation suggested by DFT calculations (see Supporting Information Section S11 for details).

The ROESY spectra acquired in water and micelle [sodium dodecyl sulfate (SDS)] solutions of the guanidine barbiturate 7 e $(3,5-\mathrm{di}-\mathrm{Br})$ were used to qualitatively assess the conformation experimentally (see Supporting Information Section 12 for details of the NMR conformational analysis). The structural NMR data in water (Figure 7, left side) supported the orientations of the benzylic side chains described by the DFT calculations. It was evident from the ROESY detectable correlations between $\mathrm{H} 7$ and $\mathrm{H} 10-\mathrm{H} 12$ (5-10\% of the reference volume) that the benzylic side chains and the barbiturate ring adopted the $\mathrm{W}$-shape (similar to the $7 \mathbf{e}_{\text {up }}$ conformation in Figure 6). There were no dramatic conformational changes in SDS, but there was a shift of populations that made the guanidine side chains spend more time closer to the 3,5-dibromophenyl rings (Figure 7, right side). This was reflected in the volumes of the $\mathrm{H} 7 / \mathrm{H} 11,12$ cross-peaks that increased from $\sim 10$ to $\sim 40 \%$ of the reference volume.

MD simulations were used to elucidate details on the membrane interactions of 7 e (3,5-di-Br) with an E. coli inner membrane model (Figure 8). ${ }^{39}$ Similar MD simulations of 6 a (4- $\left.\mathrm{CF}_{3}\right)$, 6e (3,5-di-Br), 6g (4-tBu), and $7 \mathrm{~g}(4-\mathrm{tBu})$ are included in the Supporting Information (Table S3 and Figures S6-S10), and a possible explanation to the low potency of 6 a $\left(4-\mathrm{CF}_{3}\right)$ is included below. For each compound, three parallel simulations were performed.

The course of the membrane insertion was tracked by following the location of the $\mathrm{sp}^{3}$ carbon opposite from the carbonyl carbon $\left(\mathrm{C}_{5}\right)$, as noted by the $z$-coordinate position in the simulation box (Figure 8B). The lipid bilayer surface (black 

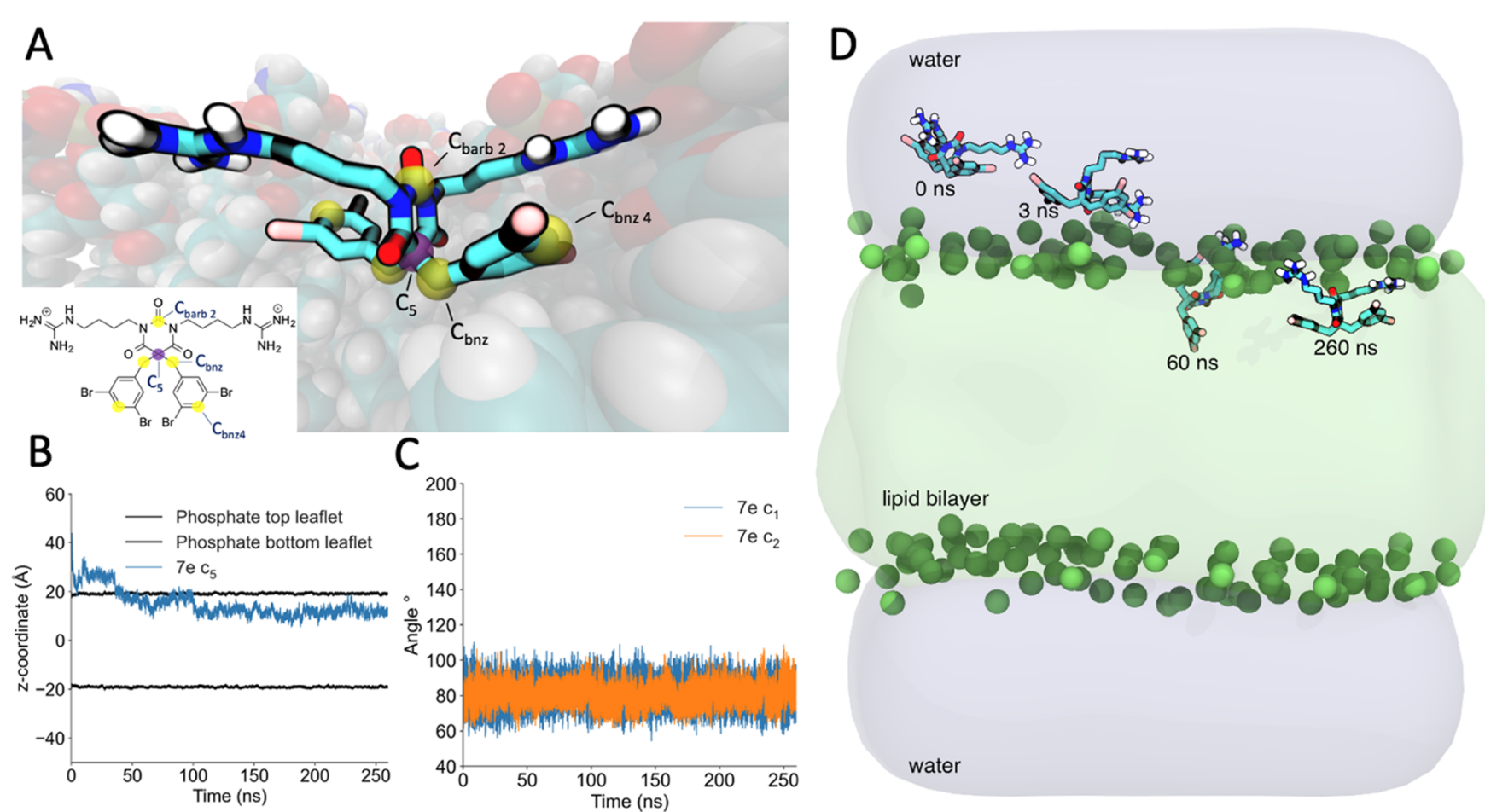

Figure 8. MD simulations of the interactions and conformations of 7e (3,5-di-Br) in an E. coli inner membrane model. (A) 7e (3,5-di-Br) in the membrane environment after $260 \mathrm{~ns}$ and the naming of atoms used for tracking of the compound. The purple sphere highlights carbon $\mathrm{C}_{5}$, which was the atom used for tracking the position of $7 \mathrm{e}(3,5$-di-Br) with respect to the PL headgroups ( $z$-coordinate). The yellow spheres highlight atoms $\mathrm{C}_{\mathrm{barb} 2}, \mathrm{C}_{\mathrm{bnz}}$ and $\mathrm{C}_{\mathrm{bnz}}$, which formed the tracked angles $c_{1}$ or $c_{2}$ representing the conformation of two benzylic side chains. (B) Time evolution for location of the $\mathrm{C}_{5}$ carbon (blue line) of $7 \mathbf{e}(3,5-\mathrm{di}-\mathrm{Br})$ in the simulation box. The lipid bilayer surface (black line) is shown as the average position of the phosphorous atoms ( $z$-coordinate, -20 and $20 \AA$ ) of the PL headgroups. (C) Tracking of the two angles $c_{1}$ (in blue) and $c_{2}$ (in orange), which revealed if the compound remained in the up conformation or changed to the up-down conformation. Since both the blue and orange lines in the shown parallel oscillated around $80^{\circ}$, the compound was in the up conformation. When one of the lines also oscillated around $140^{\circ}$ (not shown), the compound adopted the up-down conformation. (D) Simplified side view of the MD simulation system. Light gray pads represent water, light green pad in the middle is the PL bilayer, green spheres at the upper and lower borders of the PL bilayer are phosphorous atoms of the lipid headgroups, and the repeated copies of a small molecule in the upper half of the image is the 7e (3,5-di-Br) compound. The time evolution of $7 \mathrm{e}(3,5-\mathrm{di}-\mathrm{Br})$ is shown as snapshots from the simulation and spanning from left to right; 0, 3, 60, and $260 \mathrm{~ns}$. Explicit water molecules, PL tails and headgroups, ions, and non-polar hydrogen atoms in $7 \mathrm{e}(3,5-\mathrm{di}-\mathrm{Br})$ are omitted for clarity.

lines) is shown as the average position of the phosphorous atoms of the PL headgroups ( $z$-coordinate, -20 and $20 \AA$ ). The blue line shows the time evolution for location of the $\mathrm{C}_{5}$ carbon of $7 \mathrm{e}(3,5-\mathrm{di}-\mathrm{Br})$. The MD simulations for compounds 6e (3,5-di-Br), 6g (4-tBu), 7e (3,5-di-Br), and $7 \mathrm{~g}$ (4-tBu) revealed a rapid membrane insertion between 7 and $35 \mathrm{~ns}$, which was as expected due to the electrostatic interaction between the negatively charged membrane surface and the positively charged compounds.

The starting conformation of $7 \mathbf{e}(3,5-\mathrm{di}-\mathrm{Br})$ in the $\mathrm{MD}$ simulations was up. In the shown simulation parallel in Figure $8 \mathrm{C}$, tracking of the two angles $c_{1}$ (blue) and $c_{2}$ (orange), representing the two benzylic side chains, revealed that $7 \mathrm{e}$ (3,5-di-Br) remained in the up conformation throughout this simulation. This is shown by the blue and orange lines both oscillating around $80^{\circ}$, as opposed to if one of the lines was also oscillating around $140^{\circ}$, indicating an up-down conformation (Figure 8C). As shown in the Supporting Information, however, the conformations of all modeled compounds varied between the up and up-down conformations in at least one of the three parallels, and the changes from up to the up-down conformation occurred sometime between 60 and 255 ns (Table S3 and Figures S6-S10). In most parallels of the $\mathrm{MD}$ simulation, the compounds remained incorporated in the membrane throughout the duration of the simulation. Except for 6a $\left(4-\mathrm{CF}_{3}\right)$ as described below, if a molecule left the membrane, it was only for a few nanoseconds before it returned to the membrane environment, as can be seen from the time evolution of the C5 $z$-coordinate for the other modeled compounds.

A simplified side view of the MD simulation system is presented in Figure 8D, which shows the interaction of $7 \mathbf{e}$ (3,5-di-Br) with an E. coli inner membrane model. This includes a water pad over and under the PL bilayer, a PL bilayer in the middle, the phosphorous atoms of the lipid headgroups, and the location and time evolution of $7 \mathbf{e}$ (3,5-di$\mathrm{Br}$ ) when interacting with the model membrane.

A reference set of simulations were also run with $6 \mathbf{a}\left(4-\mathrm{CF}_{3}\right)$ to investigate the selectivity of the membrane model. As described above, compound $\mathbf{6 a}\left(4-\mathrm{CF}_{3}\right)$ was much less potent against E. coli (MIC: $128 \mu \mathrm{g} / \mathrm{mL}$ ) compared to the other modeled compounds. The simulations also showed that 6 a (4$\mathrm{CF}_{3}$ ) had less affinity to remain in the model membrane environment compared to the other compounds (Table S3 and Figure S6). In all the three parallels of MD simulations of $\mathbf{6 a}$ (4- $\left.\mathrm{CF}_{3}\right)$, it entered and left the membrane environment several times. This contrasted with the behavior seen in the simulations of $6 \mathrm{e}(3,5-\mathrm{di}-\mathrm{Br}), \mathbf{6 g}(4-\mathrm{tBu}), 7 \mathrm{e}(3,5-\mathrm{di}-\mathrm{Br})$, and $7 \mathrm{~g}(4-\mathrm{tBu})$ where once incorporated, the compounds remained in the membrane environment. The conformation of 6a (4- 
$\mathrm{CF}_{3}$ ) varied between up and up-down, but there was an increase in events where $6 \mathrm{a}\left(4-\mathrm{CF}_{3}\right)$ returned from up-down to the up conformation (Figure S6). This behavior was not observed for other compounds in the $\mathrm{MD}$ simulations where only the shift from up to up-down was observed. As can be seen from Figure S6, 6a $\left(4-\mathrm{CF}_{3}\right)$ also traveled out from the top of the simulation box and appeared at the bottom side of the simulation box and did this several times during the $260 \mathrm{~ns}$ simulation (Table S3). The periodic boundary conditions in the MD simulations allowed the free flow of molecules in and out of the simulation box. The behavior of $6 \mathrm{a}\left(4-\mathrm{CF}_{3}\right)$ compared to the other modeled compounds suggested that $6 \mathrm{a}$ $\left(4-\mathrm{CF}_{3}\right)$ did not find favorable interactions in the membrane environment, and this may in part explain its low antimicrobial potency against E. coli.

\section{CONCLUSIONS}

In order to succeed transforming AMPs with non-optimal pharmacokinetic properties into clinical useful antimicrobials, an innovative strategy is to develop SMAMPs with imperative functional side chains embodied on a peptidomimetic scaffold. We have in the present study developed a novel peptidomimetic scaffold that fulfills the pharmacophore model of small AMPs and that was inspired by the marine antimicrobials eusynstyelamides. Compared to the structure of the eusynstyelamides, this novel series of cationic amphipathic barbiturates is achiral and easy to modify synthetically with respect to variation in cationic and lipophilic groups for optimization studies. The relative ease of synthesis has important implications for reducing future production costs and enabling large-scale production, which is an argument often raised against several classes of AMPs. We achieved improved antimicrobial activity compared with the eusynstyelamides, and several of the barbiturates displayed high antimicrobial activity against a panel of 30 multi-resistant clinical isolates of Gram-positive and Gram-negative bacteria. This included high activity against Gram-negative ESBLCARBA isolates and strains resistant to the last resort antibiotic colistin. A pilot in vivo study using a murine neutropenic peritonitis model demonstrated that the overall most potent lead peptidomimetic 7 e (3,5-di-Br) significantly reduced the number of viable bacterial cells of clinical isolates of E. coli and K. pneumoniae. Although further structural optimizations are required to improve the MTD in mice, as well as pharmacokinetic studies including exploration of different routes of administration, demonstration of in vivo efficacy gives hope to the drug potential of this class of SMAMPs for treatment of serious infections.

\section{EXPERIMENTAL SECTION}

Chemicals and Equipment. All reagents and solvents were purchased from commercial sources and used as supplied with the exception of the starting material 1-(bromomethyl)-4-fluoronaphthalene, which was synthesized from the 4-fluoro-1-naphthoic acid according to the literature procedures. ${ }^{40}$ Anhydrous DMF was prepared by storage over $4 \AA$ molecular sieves. The reactions were monitored by thin-layer chromatography (TLC) with Merck precoated silica gel plates $\left(60 \mathrm{~F}_{254}\right)$. Visualization was accomplished with either UV light or by immersion in potassium permanganate or phosphomolybdic acid (PMA), followed by light heating with a heating gun. Purifications using normal phase flash chromatography were either done by normal column chromatography using Normal Sil $60,40-63 \mathrm{~mm}$ silica gel, or by automated normal phase flash chromatography (heptane/EtOAc) with the sample preloaded on a
Samplet cartridge belonging to a Biotage SP-1. Purification of reactions by $\mathrm{RP}_{18}$ column chromatography (water with $0.1 \% \mathrm{TFA}$ / acetonitrile with $0.1 \%$ TFA) was also executed on an automated purification module with the sample preloaded on a Samplet cartridge. All samples used for biological testing were determined to be of $>95 \%$ purity. The analyses were carried out on a Waters ACQUITY UPC 2 system equipped with a Torus DEA $130 \AA$ A $1.7 \mu \mathrm{m}, 2.1 \mathrm{~mm} \times 50 \mathrm{~mm}$ column coupled to a Waters ACQUITY PDA detector spanning from wavelengths $190-650 \mathrm{~nm}$. The derivatives were eluted with a mobile phase consisting of supercritical $\mathrm{CO}_{2}$ and $\mathrm{MeOH}$ containing $0.1 \%$ $\mathrm{NH}_{3}$ and a linear gradient of $2-40 \% \mathrm{MeOH}$ over 2 or $4 \mathrm{~min}$, followed by isocratic $0.5 \mathrm{~min}$ of $40 \% \mathrm{MeOH}$. The flow rate was $1.5 \mathrm{~mL} / \mathrm{min}$. NMR spectra were obtained on a $400 \mathrm{MHz}$ Bruker Avance III HD equipped with a $5 \mathrm{~mm}$ SmartProbe $\mathrm{BB} /{ }^{1} \mathrm{H}\left(\mathrm{BB}={ }^{19} \mathrm{~F},{ }^{31} \mathrm{P}-{ }^{15} \mathrm{~N}\right)$. Data are represented as follows: chemical shift, multiplicity ( $s=$ singlet, $\mathrm{d}=$ doublet, $\mathrm{t}=$ triplet, $\mathrm{q}=$ quartet, $\mathrm{p}=$ pentet, $\mathrm{h}=$ heptet, and $\mathrm{m}=$ multiplet), coupling constant $(\mathrm{J}, \mathrm{Hz})$, and integration. Chemical shifts $(\delta)$ are reported in ppm relative to the residual solvent peak $\left(\mathrm{CDCl}_{3}\right.$ : $\delta_{\mathrm{H}} 7.26$ and $\delta_{\mathrm{C}} 77.16 ; \mathrm{CD}_{3} \mathrm{OD}: \delta_{\mathrm{H}} 3.31$ and $\left.\delta_{\mathrm{C}} 49.00\right)$. Positive and negative ion electrospray ionization mass spectrometry (ESI-MS) was conducted on a Thermo electron LTQ Orbitrap XL spectrometer.

Synthesis. Dialkylated Malonate Ester $(\mathbf{2} \boldsymbol{a}-\mathbf{g})$. General Procedure. To a stirred solution of diethyl malonate in DMF $(\approx 100 \mathrm{mg} / \mathrm{mL})$ and base was added arylmethyl halide ( $\sim 2$ equiv). The reaction was continuously stirred at room temperature overnight. The reaction mixture was diluted with EtOAc $(30 \mathrm{~mL})$ and washed with water $(25 \mathrm{~mL})$, aqueous $5 \% \mathrm{LiCl}$ solution $(3 \times 25 \mathrm{~mL})$, and brine $(25 \mathrm{~mL})$. The organic phase was dried over $\mathrm{Na}_{2} \mathrm{SO}_{4}$, filtered, and concentrated. The crude product was dissolved in $\mathrm{CH}_{2} \mathrm{Cl}_{2}(20$ $\mathrm{mL}$ ) and adsorbed on Celite. The product was purified on a silica column using 1-5\% EtOAc in pentane as the mobile phase.

Diethyl 2,2-Bis(4-(trifluoromethyl)benzyl)malonate (2a). According to the general procedure, to a stirred solution of diethyl malonate $(3.26 \mathrm{~g}, 20.4 \mathrm{mmol})$ in DMF $(25 \mathrm{~mL})$ over $\mathrm{K}_{2} \mathrm{CO}_{3}(8.5 \mathrm{~g}, 61.2$ mmol) was added 1-(bromomethyl)-4-(trifluoromethyl)benzene (10 $\mathrm{g}, 41.8 \mathrm{mmol})$. The reaction was stirred at room temperature overnight. The reaction mixture was diluted with EtOAc $(75 \mathrm{~mL})$ and washed with water $(5 \times 50 \mathrm{~mL})$, aqueous $5 \% \mathrm{LiCl}$ solution $(30 \mathrm{~mL})$, and brine $(40 \mathrm{~mL})$. The organic phase was dried over $\mathrm{Na}_{2} \mathrm{SO}_{4}$, filtered, and concentrated. The crude product $(9.97 \mathrm{~g})$ was dissolved in $\mathrm{CH}_{2} \mathrm{Cl}_{2}(50 \mathrm{~mL})$ and adsorbed on Celite. The product was purified on a silica column using 1-5\% EtOAc in pentane as the mobile phase to afford 2a (8.64 g, 89\%) as a white solid. ${ }^{1} \mathrm{H}$ NMR (400 MHz, $\left.\mathrm{CDCl}_{3}\right): \delta 7.54(\mathrm{~d}, J=8.1 \mathrm{~Hz}, 4 \mathrm{H}), 7.28(\mathrm{~d}, J=8.1 \mathrm{~Hz}, 4 \mathrm{H}), 4.10(\mathrm{q}$, $J=7.2 \mathrm{~Hz}, 4 \mathrm{H}), 3.27(\mathrm{~s}, 4 \mathrm{H}), 1.13(\mathrm{t}, J=7.1 \mathrm{~Hz}, 6 \mathrm{H}) .{ }^{13} \mathrm{C}$ NMR $\left(101 \mathrm{MHz}, \mathrm{CDCl}_{3}\right): \delta 170.5,140.4\left(\mathrm{~d},{ }^{4} J_{\mathrm{C}, \mathrm{F}}=1.8 \mathrm{~Hz}\right), 130.6,129.6$ $\left(\mathrm{q},{ }^{2} J_{\mathrm{C}, \mathrm{F}}=32.5 \mathrm{~Hz}\right), 125.3\left(\mathrm{q},{ }^{3} J_{\mathrm{C}, \mathrm{F}}=3.8 \mathrm{~Hz}\right), 124.3\left(\mathrm{q},{ }^{1} J_{\mathrm{C}, \mathrm{F}}=271.9\right.$ $\mathrm{Hz}), 61.7,60.1,39.8$, 13.9. HRMS-ESI: $\mathrm{C}_{23} \mathrm{H}_{22} \mathrm{~F}_{6} \mathrm{NaO}_{4}^{+}[\mathrm{M}+\mathrm{Na}]^{+}$ calcd, 499.1315; found, 499.1298 .

Diethyl 2,2-Bis(naphthalen-2-yl-methyl)malonate (2b). To a stirred solution of diethyl malonate $(3.44 \mathrm{~g}, 21.5 \mathrm{mmol})$ in $15 \mathrm{~mL}$ of $\mathrm{CH}_{2} \mathrm{Cl}_{2}$ at $0{ }^{\circ} \mathrm{C}$ was added $\mathrm{DBU}(3.3 \mathrm{~mL}, 22.6 \mathrm{mmol})$. The reaction mixture was stirred for $5 \mathrm{~min}$ before adding 2 (bromomethyl)naphthalene $(5.0 \mathrm{~g}, 22.6 \mathrm{mmol})$. The reaction was allowed to reach room temperature and stirred overnight. The reaction was concentrated, and the crude product isolated as a brown oil. The oil was dissolved in EtOAc $(30 \mathrm{~mL})$ and washed with water $(2 \times 30 \mathrm{~mL}), 10 \%$ citric acid $(30 \mathrm{~mL}), 10 \% \mathrm{NaHCO}_{3}$ soln $(30 \mathrm{~mL})$, and brine $(30 \mathrm{~mL})$. The organic phase was dried over $\mathrm{Na}_{2} \mathrm{SO}_{4}$, filtered, and concentrated affording $4.83 \mathrm{~g}$ of almost pure monoalkylated diethyl malonate. To a suspension of $\mathrm{NaH}(774 \mathrm{mg}$, $32.2 \mathrm{mmol})$ in dry THF $(15 \mathrm{~mL})$ at $0{ }^{\circ} \mathrm{C}$ was added diethyl 2(naphthalen-2-ylmethyl)malonate $(4.8 \mathrm{~g})$ dropwise as a solution in THF $(15 \mathrm{~mL})$. The resulting mixture was stirred for $10 \mathrm{~min}$ before adding 2-naphtyl methyl bromide ( $5 \mathrm{~g}, 22.6 \mathrm{mmol}$ ). The reaction was allowed to reach room temperature and stirred overnight. The reaction mixture was cooled in an ice bath, unreacted $\mathrm{NaH}$ was quenched with $10 \%$ citric acid solution, and the reaction mixture was concentrated. The crude product was then dissolved in EtOAc and washed with $10 \%$ citric acid soln $(3 \times 30 \mathrm{~mL}), 10 \% \mathrm{NaHCO}_{3}$ soln $(2$ 
$\times 30 \mathrm{~mL})$, and brine $(30 \mathrm{~mL})$. The organic phase was dried over $\mathrm{Na}_{2} \mathrm{SO}_{4}$, filtered, and concentrated to afford crude $\mathbf{2 b}(7.35 \mathrm{~g}, 78 \%)$. ${ }^{1} \mathrm{HNMR}\left(400 \mathrm{MHz}, \mathrm{CDCl}_{3}\right): \delta 7.85-7.80(\mathrm{~m}, 2 \mathrm{H}), 7.77(\mathrm{~d}, J=8.1$ $\mathrm{Hz}, 4 \mathrm{H}), 7.65(\mathrm{~d}, J=1.7 \mathrm{~Hz}, 2 \mathrm{H}), 7.49-7.43(\mathrm{~m}, 4 \mathrm{H}), 7.32(\mathrm{dd}, J=$ $8.5,1.7 \mathrm{~Hz}, 2 \mathrm{H}), 4.14(\mathrm{q}, J=7.1 \mathrm{~Hz}, 4 \mathrm{H}), 3.45(\mathrm{~s}, 4 \mathrm{H}), 1.14(\mathrm{t}, J=$ $7.1 \mathrm{~Hz}, 6 \mathrm{H}) .{ }^{13} \mathrm{C}$ NMR not determined. HRMS-ESI: $\mathrm{C}_{29} \mathrm{H}_{29} \mathrm{O}_{4}{ }^{+}[\mathrm{M}+$ $\mathrm{H}]^{+}$calcd, 441.2060; found, 441.2059 .

Diethyl 2,2-Bis((4-fluoronaphthalene-1-yl)methyl)malonate (2c). According to the general procedure, to a stirred solution of diethyl malonate $(1.3 \mathrm{~g}, 8.16 \mathrm{mmol})$ in DMF $(10 \mathrm{~mL})$ over $\mathrm{K}_{2} \mathrm{CO}_{3}(3.36 \mathrm{~g}$, $24.3 \mathrm{mmol}$ ) was added 1-(bromomethyl)-4-fluoronaphthalene (4 g, $16.7 \mathrm{mmol}$ ). The reaction was continuously stirred at room temperature overnight. The reaction mixture was diluted with EtOAc $(30 \mathrm{~mL})$ and washed with water $(3 \times 20 \mathrm{~mL})$, aqueous $5 \%$ $\mathrm{LiCl}$ solution $(20 \mathrm{~mL})$, and brine $(20 \mathrm{~mL})$. The organic phase was dried over $\mathrm{Na}_{2} \mathrm{SO}_{4}$, filtered, and concentrated. In a round-bottomed flask, the brown solid crude product was dissolved in warm EtOH, capped with alumina foil, and left for 4 days at room temperature. Upon standing for an hour, the product $2 \mathrm{c}$ crashed out of the brown solution as a white solid (1.6 g, 41\%). ${ }^{1} \mathrm{H}$ NMR $\left(400 \mathrm{MHz}, \mathrm{CDCl}_{3}\right)$ : $\delta 8.18-8.08(\mathrm{~m}, 2 \mathrm{H}), 8.05-7.95(\mathrm{~m}, 2 \mathrm{H}), 7.57-7.46(\mathrm{~m}, 4 \mathrm{H}), 7.36$ (dd, $J=8.0,5.5 \mathrm{~Hz}, 2 \mathrm{H}), 7.04(\mathrm{dd}, J=10.2,8.0 \mathrm{~Hz}, 2 \mathrm{H}), 3.81(\mathrm{~s}$, $4 \mathrm{H}), 3.75(\mathrm{q}, J=7.2 \mathrm{~Hz}, 4 \mathrm{H}), 0.85(\mathrm{t}, J=7.1 \mathrm{~Hz}, 6 \mathrm{H}) .{ }^{13} \mathrm{C} \mathrm{NMR}$ $\left(101 \mathrm{MHz}, \mathrm{CDCl}_{3}\right): \delta 171.3,158.1\left(\mathrm{~d}, J_{\mathrm{C}, \mathrm{F}}=251.4 \mathrm{~Hz}\right), 134.2\left(\mathrm{~d}, J_{\mathrm{C}, \mathrm{F}}\right.$ $=4.2 \mathrm{~Hz}), 128.9\left(\mathrm{~d}, J_{\mathrm{C}, \mathrm{F}}=4.6 \mathrm{~Hz}\right), 127.6\left(\mathrm{~d}, J_{\mathrm{C}, \mathrm{F}} J=8.2 \mathrm{~Hz}\right), 126.8$, $125.9\left(\mathrm{~d}, J_{\mathrm{C}, \mathrm{F}}=2.1 \mathrm{~Hz}\right), 124.1-123.9(\mathrm{~m}), 121.2\left(\mathrm{~d}, J_{\mathrm{C}, \mathrm{F}}=6.0 \mathrm{~Hz}\right)$, $108.9\left(\mathrm{~d}, J_{\mathrm{C}, \mathrm{F}}=19.7 \mathrm{~Hz}\right), 61.5,59.8,35.5$, 13.6. HRMS-ESI: $\mathrm{C}_{29} \mathrm{H}_{26} \mathrm{~F}_{2} \mathrm{NaO}_{4}^{+}[\mathrm{M}+\mathrm{Na}]^{+}$calcd, 499.1691; found, 499.1689.

Diethyl 2,2-Bis(4-bromo-3-chlorobenzyl)malonate (2d). According to the general procedure, to a stirred solution of diethyl malonate $(313 \mathrm{mg}, 1.95 \mathrm{mmol})$ in DMF $(6 \mathrm{~mL})$ over $\mathrm{Cs}_{2} \mathrm{CO}_{3}(1.91 \mathrm{~g}, 5.86$ mmol) was added 1-bromo-4-(bromomethyl)-2-chlorobenzene (1.14 $\mathrm{g}, 4.01 \mathrm{mmol})$. The reaction was continuously stirred at $40{ }^{\circ} \mathrm{C}$ for 22 $\mathrm{h}$. The reaction mixture was diluted with EtOAc $(20 \mathrm{~mL})$ and washed with aqueous $5 \% \mathrm{LiCl}$ solution $(3 \times 20 \mathrm{~mL})$. The organic phase was dried over $\mathrm{MgSO}_{4}$, filtered, and concentrated. The crude product was dissolved in $\mathrm{CH}_{2} \mathrm{Cl}_{2}(20 \mathrm{~mL})$ and adsorbed on Celite. The product was purified on a silica column using $5 \%$ EtOAc in heptane as the mobile phase to afford $2 \mathrm{~d}(1.04 \mathrm{~g}, 94 \%)$ as a white solid. ${ }^{1} \mathrm{H}$ NMR $\left(400 \mathrm{MHz}, \mathrm{CDCl}_{3}\right): \delta 7.50(\mathrm{~d}, J=8.3 \mathrm{~Hz}, 2 \mathrm{H}), 7.24(\mathrm{~d}, J=2.1 \mathrm{~Hz}$, $2 \mathrm{H}), 6.91(\mathrm{dd}, J=8.3,2.1 \mathrm{~Hz}, 2 \mathrm{H}), 4.13(\mathrm{q}, J=7.1 \mathrm{~Hz}, 4 \mathrm{H}), 3.12(\mathrm{~s}$, $4 \mathrm{H}), 1.18(\mathrm{t}, J=7.1 \mathrm{~Hz}, 6 \mathrm{H}) .{ }^{13} \mathrm{C} \mathrm{NMR}\left(101 \mathrm{MHz}, \mathrm{CDCl}_{3}\right): \delta 170.3$, 137.1, 134.4, 133.6, 132.1, 129.8, 121.2, 61.9, 59.9, 39.1, 14.0. HRMSESI: $\mathrm{C}_{21} \mathrm{H}_{20} \mathrm{Br}_{2} \mathrm{Cl}_{2} \mathrm{O}_{4}^{+}[\mathrm{M}+\mathrm{Na}]^{+}$calcd, 586.8998; found, 586.9005.

Diethyl 2,2-Bis(3,5-dibromobenzyl)malonate (2e). According to the general procedure, to a stirred solution of diethyl malonate (460 $\mathrm{mg}, 2.9 \mathrm{mmol})$ in DMF $(5 \mathrm{~mL})$ over $\mathrm{Cs}_{2} \mathrm{CO}_{3}(2.0 \mathrm{~g}, 6.37 \mathrm{mmol})$ was added 1,3-dibromo-5(bromomethyl)benzene ( $2.0 \mathrm{~g}, 6.0 \mathrm{mmol})$. The reaction was continuously stirred at room temperature overnight. The reaction mixture was diluted with EtOAc $(30 \mathrm{~mL})$ and washed with water $(25 \mathrm{~mL})$, aqueous $5 \% \mathrm{LiCl}$ solution $(3 \times 25 \mathrm{~mL})$, and brine $(25$ $\mathrm{mL})$. The organic phase was dried over $\mathrm{Na}_{2} \mathrm{SO}_{4}$, filtered, and concentrated. The crude product was dissolved in $\mathrm{CH}_{2} \mathrm{Cl}_{2}(20 \mathrm{~mL})$ and adsorbed on Celite. The product was purified on a silica column using 1-5\% EtOAc in pentane as the mobile phase to afford $2 \mathrm{e}(1.17$ $\mathrm{g}, 61 \%)$ as a white solid. ${ }^{1} \mathrm{H} \mathrm{NMR}\left(400 \mathrm{MHz}, \mathrm{CDCl}_{3}\right): \delta 7.56(\mathrm{t}, J=$ $1.8 \mathrm{~Hz}, 2 \mathrm{H}), 7.24(\mathrm{~d}, J=1.8 \mathrm{~Hz}, 4 \mathrm{H}), 4.15(\mathrm{q}, J=7.1 \mathrm{~Hz}, 4 \mathrm{H}), 3.11$ $(\mathrm{s}, 4 \mathrm{H}), 1.20(\mathrm{t}, J=7.2 \mathrm{~Hz}, 6 \mathrm{H}) \cdot{ }^{13} \mathrm{C} \mathrm{NMR}\left(101 \mathrm{MHz}, \mathrm{CDCl}_{3}\right): \delta$ 170.0, 139.9, 132.8, 132.0, 122.7, 61.9, 60.0, 39.3, 13.9. HRMS-ESI: $\mathrm{C}_{21} \mathrm{H}_{20} \mathrm{Br}_{4} \mathrm{NaO}_{4}^{+}[\mathrm{M}+\mathrm{Na}]^{+}$calcd, 674.7987; found, 674.7961.

Diethyl 2,2-Bis(3,5-bis(trifluoromethyl)benzyl)malonate (2f). According to the general procedure, to a stirred solution of diethyl malonate $(490 \mathrm{mg}, 3.1 \mathrm{mmol})$ in DMF $(5 \mathrm{~mL})$ over $\mathrm{Cs}_{2} \mathrm{CO}_{3}(2.2 \mathrm{~g}$, $6.83 \mathrm{mmol}$ ) was added 1-(bromomethyl)-3,5-bis(trifluoromethyl)benzene $(2 \mathrm{~g}, 6.51 \mathrm{mmol})$. The reaction was continuously stirred at room temperature overnight. The reaction mixture was diluted with EtOAc $(30 \mathrm{~mL})$ and washed with water $(25 \mathrm{~mL})$, aqueous $5 \% \mathrm{LiCl}$ solution $(3 \times 25 \mathrm{~mL})$, and brine $(25 \mathrm{~mL})$. The organic phase was dried over $\mathrm{Na}_{2} \mathrm{SO}_{4}$, filtered, and concentrated. The crude product was dissolved in $\mathrm{CH}_{2} \mathrm{Cl}_{2}(20 \mathrm{~mL})$ and adsorbed on Celite. The product was purified on a silica column using $1-5 \%$ EtOAc in pentane as the mobile phase to afford $2 \mathrm{f}(0.89 \mathrm{~g}, 63 \%)$ as a white solid. ${ }^{1} \mathrm{H}$ NMR $\left(400 \mathrm{MHz} \mathrm{CDCl}_{3}\right): \delta 7.79(\mathrm{~s}, 2 \mathrm{H}), 7.71-7.54(\mathrm{~m}, 4 \mathrm{H}), 4.10(\mathrm{q}, \mathrm{J}=$ $7.1 \mathrm{~Hz}, 4 \mathrm{H}), 3.32(\mathrm{~s}, 4 \mathrm{H}), 1.13(\mathrm{t}, \mathrm{J}=7.1 \mathrm{~Hz}, 6 \mathrm{H}) .{ }^{13} \mathrm{C}$ NMR $(101$ $\left.\mathrm{MHz}, \mathrm{CDCl}_{3}\right): \delta 169.8,138.5,131.8\left(\mathrm{q},{ }^{2} \mathrm{~J}_{\mathrm{C}, \mathrm{F}}=33.3 \mathrm{~Hz}\right), 130.9-$ $130.2(\mathrm{~m}), 123.3\left(\mathrm{q},{ }^{1} J_{\mathrm{C}, \mathrm{F}}=272.7 \mathrm{~Hz}\right), 121.5\left(\mathrm{p},{ }^{3} J_{\mathrm{C}, \mathrm{F}}=3.9 \mathrm{~Hz}\right), 62.2$, 60.3, 40.3, 13.8. HRMS-ESI: $\mathrm{C}_{25} \mathrm{H}_{19} \mathrm{~F}_{12} \mathrm{O}_{4}^{-}[\mathrm{M}-\mathrm{H}]^{-}$calcd, 611.1098; found, 611.1097.

Diethyl 2,2-Bis(4-tert-butylbenzyl)malonate (2g). According to the general procedure, to a stirred solution of diethyl malonate ( 3.43 $\mathrm{g}, 21.4 \mathrm{mmol})$ in DMF $(25 \mathrm{~mL})$ over $\mathrm{K}_{2} \mathrm{CO}_{3}(8.8 \mathrm{~g}, 64.2 \mathrm{mmol})$ was added 1-(bromomethyl)-4-tert-butylbenzene (10 g, $44 \mathrm{mmol})$. The reaction was continuously stirred at room temperature overnight. The reaction mixture was diluted with EtOAc $(80 \mathrm{~mL})$ and washed with water $(3 \times 50 \mathrm{~mL})$, aqueous $5 \% \mathrm{LiCl}$ solution $(50 \mathrm{~mL})$, and brine $(50$ $\mathrm{mL})$. The organic phase was dried over $\mathrm{Na}_{2} \mathrm{SO}_{4}$, filtered, and concentrated. The crude product was dissolved in $\mathrm{CH}_{2} \mathrm{Cl}_{2}(20 \mathrm{~mL})$ and adsorbed on to Celite. The product was purified on a silica column using $1-5 \%$ EtOAc in pentane as the mobile phase to afford $2 \mathrm{~g}(8.80 \mathrm{~g}, 90 \%)$ as a white solid. ${ }^{1} \mathrm{H}$ NMR $\left(400 \mathrm{MHz}, \mathrm{CDCl}_{3}\right): \delta$ $7.28(\mathrm{~d}, J=8.3 \mathrm{~Hz}, 4 \mathrm{H}), 7.11(\mathrm{~d}, J=8.4 \mathrm{~Hz}, 4 \mathrm{H}), 4.10(\mathrm{q}, J=7.1 \mathrm{~Hz}$, $4 \mathrm{H}), 3.19(\mathrm{~s}, 4 \mathrm{H}), 1.30(\mathrm{~s}, 18 \mathrm{H}), 1.14(\mathrm{t}, J=7.1 \mathrm{~Hz}, 6 \mathrm{H}) .{ }^{13} \mathrm{C} \mathrm{NMR}$ $\left(101 \mathrm{MHz} \mathrm{CDCl}_{3}\right): \delta 171.2,149.7,133.4,129.9,125.2,61.2,60.4$, 38.6, 34.5, 31.5, 14.0. HRMS-ESI: $\mathrm{C}_{29} \mathrm{H}_{40} \mathrm{NaO}_{4}^{+}[\mathrm{M}+\mathrm{Na}]^{+}$calcd, 475.2818; found, 475.2795 .

Condensation of Malonates (2) with Urea to Barbiturates (3). 5,5-Bis(4-trifluoromethylbenzyl)pyrimidine-2,4,6(1H,3H,5H)-trione (3a). To a solution of urea $(3.15 \mathrm{~g}, 52.5 \mathrm{mmol})$ in anhydrous DMF $(15 \mathrm{~mL})$ was added $\mathrm{NaH}(315 \mathrm{mg}, 13.1 \mathrm{mmol})$. The reaction mixture was stirred $5 \mathrm{~min}$ before adding a solution of $2 \mathrm{a}(2.5 \mathrm{~g}, 5.22 \mathrm{mmol})$ in anhydrous DMF $(10 \mathrm{~mL})$ dropwise. The reaction mixture was left under stirring overnight until TLC showed full conversion using $5 \%$ EtOAc in $\mathrm{CHCl}_{3}$ as the mobile phase $\left[R_{\mathrm{f}}\right.$ (product) $0.38, R_{\mathrm{f}}$ (starting material) 0.89]. The reaction was diluted with $100 \mathrm{~mL}$ of EtOAc and washed with $10 \%$ citric acid soln $(3 \times 50 \mathrm{~mL}), 10 \% \mathrm{NaHCO}_{3}$ soln $(2$ $\times 50 \mathrm{~mL})$, and brine $(2 \times 50 \mathrm{~mL})$. The organic phase was dried over $\mathrm{Na}_{2} \mathrm{SO}_{4}$, filtered, and concentrated, yielding the crude product (2.39 g). The crude was dissolved in $\mathrm{CH}_{2} \mathrm{Cl}_{2}$ and adsorbed onto Celite before being purified on a silica column using $5 \% \mathrm{EtOAc}$ in $\mathrm{CHCl}_{3}$ as the mobile phase to afford $3 \mathrm{a}(1.63 \mathrm{~g}, 70 \%)$ as a white solid. ${ }^{1} \mathrm{H}$ NMR $\left(400 \mathrm{MHz} \mathrm{CDCl}_{3}\right): \delta 7.53(\mathrm{~d}, J=8.1 \mathrm{~Hz}, 4 \mathrm{H}), 7.26^{*}(\mathrm{~d}, 4 \mathrm{H}), 3.50$ (s, 4H). ${ }^{13} \mathrm{C}$ NMR $\left(101 \mathrm{MHz}, \mathrm{CDCl}_{3}\right): \delta 170.4,146.4,138.1,130.6$ $\left(\mathrm{q},{ }^{2} J_{\mathrm{C}, \mathrm{F}}=32.7 \mathrm{~Hz}\right), 130.2,126.0\left(\mathrm{q},{ }^{3} J_{\mathrm{C}, \mathrm{F}}=3.7 \mathrm{~Hz}\right), 124.0\left(\mathrm{q},{ }^{1} J_{\mathrm{C}, \mathrm{F}}=\right.$ $272.2 \mathrm{~Hz}), 60.3,44.3$. * Overlap with solvent. HRMS-ESI: $\mathrm{C}_{20} \mathrm{H}_{13} \mathrm{~F}_{6} \mathrm{~N}_{2} \mathrm{O}_{3}^{-}[\mathrm{M}-\mathrm{H}]^{-}$calcd, 443.0836; found, 443.0826.

5,5-Bis((naphthalen-2-yl)methyl)pyrimidine-2,4,6(1H,3H,5H)-trione $(3 \boldsymbol{b})$. $\mathrm{NaH}(9 \mathrm{mg}, 0.37 \mathrm{mmol})$ was added to a stirred solution of urea $(91 \mathrm{mg}, 1.49 \mathrm{mmol})$ in anhydrous DMF $(3 \mathrm{~mL})$ at room temperature The reaction mixture was left to stir for $10 \mathrm{~min}$ before adding $\mathbf{2 b}(66 \mathrm{mg}, 0.15 \mathrm{mmol})$ slowly, and the reaction was left to stir overnight. The reaction mixture was diluted with EtOAc $(20 \mathrm{~mL})$ and washed with water $(4 \times 20 \mathrm{~mL})$, followed by brine $(20 \mathrm{~mL})$. The organic phase was dried over $\mathrm{Na}_{2} \mathrm{SO}_{4}$, filtered, and concentrated. The crude product was dissolved in $\mathrm{CHCl}_{3}$ and adsorbed onto Celite before purification on a silica column using $0-5 \%$ EtOAc in $\mathrm{CHCl}_{3}$ as the mobile phase to afford $3 \mathbf{b}(50 \mathrm{mg}, 82 \%) .{ }^{1} \mathrm{H}$ NMR (400 MHz, $\left.\mathrm{CD}_{3} \mathrm{OD}\right): \delta 7.76-7.70(\mathrm{~m}, 4 \mathrm{H}), 7.69(\mathrm{~d}, J=8.6 \mathrm{~Hz}, 2 \mathrm{H}), 7.62(\mathrm{~s}$, $2 \mathrm{H}), 7.44-7.36(\mathrm{~m}, 4 \mathrm{H}), 7.26(\mathrm{dd}, J=8.4,1.7 \mathrm{~Hz}, 2 \mathrm{H}), 3.60(\mathrm{~s}, 4 \mathrm{H})$. ${ }^{13} \mathrm{C}$ NMR (101 MHz, CD $\left.3 \mathrm{OD}\right): \delta 173.2,149.5,133.8,133.1,132.8$, 129.1, 128.7, 128.1, 127.9, 127.8, 126.6, 126.4, 60.8, 45.1. HRMS-ESI: $\mathrm{C}_{26} \mathrm{H}_{19} \mathrm{~N}_{2} \mathrm{O}_{3}^{-}[\mathrm{M}-\mathrm{H}]^{-}$calcd, 407.1417; found, 407.1416.

5,5-Bis((4-fluoronaphthalene-1-yl)methyl)pyrimidine-2,4,6$(1 \mathrm{H}, 3 \mathrm{H}, 5 \mathrm{H})$-trione (3c). To a stirred solution of urea $(630 \mathrm{mg}, 10.49$ $\mathrm{mmol})$ in anhydrous DMF $(4 \mathrm{~mL})$ was added $\mathrm{NaH}(76 \mathrm{mg}, 3.16$ $\mathrm{mmol}$ ), and the resulting solution was stirred for $10 \mathrm{~min}$ before adding $2 \mathrm{c}(500 \mathrm{mg}, 1.05 \mathrm{mmol})$ slowly. The resulting mixture was stirred overnight. The reaction mixture was diluted with $25 \mathrm{~mL}$ of EtOAc and washed with $4 \times 50 \mathrm{~mL}$ of water, followed by $20 \mathrm{~mL}$ of brine. The organic phase was dried over $\mathrm{Na}_{2} \mathrm{SO}_{4}$, filtered, and concentrated. The crude product was dissolved in $\mathrm{CHCl}_{3}$ and 
adsorbed onto Celite before purification on a silica column using 0$5 \%$ EtOAc in $\mathrm{CHCl}_{3}$ as the mobile phase to afford $3 \mathrm{c}(430 \mathrm{mg}, 92 \%)$. ${ }^{1} \mathrm{H}$ NMR $\left(400 \mathrm{MHz}, \mathrm{CDCl}_{3}\right): \delta 8.23(\mathrm{~d}, J=8.5 \mathrm{~Hz}, 2 \mathrm{H}), 8.14-8.04$ (m, 2H), 7.64-7.49 (m, 4H), $7.46(\mathrm{~s}, 2 \mathrm{H}), 7.29-7.26^{*}(\mathrm{~m}, 2 \mathrm{H}), 7.00$ $(\mathrm{dd}, J=9.9,8.1 \mathrm{~Hz}, 2 \mathrm{H}), 4.05(\mathrm{~s}, 4 \mathrm{H}) .{ }^{13} \mathrm{C} \mathrm{NMR}(101 \mathrm{MHz}$, $\left.\mathrm{CDCl}_{3}\right): \delta 171.4,158.7\left(\mathrm{~d}, J_{\mathrm{C}, \mathrm{F}}=253.3 \mathrm{~Hz}\right), 146.8,133.3\left(\mathrm{~d}, J_{\mathrm{C}, \mathrm{F}}=\right.$ $4.5 \mathrm{~Hz}), 128.0\left(\mathrm{~d}, J_{\mathrm{C}, \mathrm{F}}=8.7 \mathrm{~Hz}\right), 127.4,126.7(\mathrm{~d}, J=4.7 \mathrm{~Hz}), 126.5$ $(\mathrm{d}, J=1.9 \mathrm{~Hz}), 124.4-124.1(\mathrm{~m}), 121.3(\mathrm{~d}, J=6.2 \mathrm{~Hz}), 109.1(\mathrm{~d}, J=$ $20.1 \mathrm{~Hz})$, 59.8, 40.0. *Overlap with solvent. HRMS-ESI: $\mathrm{C}_{26} \mathrm{H}_{17} \mathrm{~F}_{2} \mathrm{~N}_{2} \mathrm{O}_{3}^{-}[\mathrm{M}-\mathrm{H}]^{-}$calcd, 443.1213; found, 443.1181.

5,5-Bis(4-bromo-3-chlorobenzyl)pyrimidine-2,4,6(1H,3H,5H)-trione $(3 d)$. To a stirred solution of urea $(621 \mathrm{mg}, 10.3 \mathrm{mmol})$ in anhydrous DMF $(8 \mathrm{~mL})$ was added $\mathrm{NaH}(124 \mathrm{mg}, 3.1 \mathrm{mmol}, 60 \%$ in mineral oil), and the resulting solution was stirred for $20 \mathrm{~min}$ before slowly adding $2 \mathrm{~d}(586 \mathrm{mg}, 1.03 \mathrm{mmol})$, dissolved in $2 \mathrm{~mL}$ of anhydrous DMF. The resulting mixture was stirred for $20 \mathrm{~h}$. The reaction mixture was diluted with $20 \mathrm{~mL}$ of EtOAc and washed with 4 $\times 20 \mathrm{~mL}$ of aq $5 \% \mathrm{LiCl}$. The organic phase was dried over $\mathrm{MgSO}_{4}$, filtered, and concentrated. The crude product was adsorbed onto Celite before purification on a silica column using 20\% EtOAc in heptane as the mobile phase to afford 3d (364 mg, 66\%). ${ }^{1} \mathrm{H}$ NMR $\left(400 \mathrm{MHz}, \mathrm{DMSO}-d_{6}\right): \delta 11.51(\mathrm{NH}, \mathrm{s}, 2 \mathrm{H}), 7.71(\mathrm{~d}, J=8.2 \mathrm{~Hz}$, $2 \mathrm{H}), 7.24(\mathrm{~d}, J=2.1 \mathrm{~Hz}, 2 \mathrm{H}), 6.93(\mathrm{dd}, J=8.3,2.1 \mathrm{~Hz}, 2 \mathrm{H}), 3.26(\mathrm{~s}$, $4 \mathrm{H}) .{ }^{13} \mathrm{C}$ NMR (101 MHz, DMSO- $\left.d_{6}\right): \delta 171.4,148.8,136.7,134.0$, 133.0, 131.3, 129.8, 120.6, 58.2, 41.9. HRMS-ESI: $\mathrm{C}_{18} \mathrm{H}_{11} \mathrm{Br}_{2} \mathrm{Cl}_{2} \mathrm{~N}_{2} \mathrm{O}_{3}^{-}[\mathrm{M}-\mathrm{H}]^{-}$calcd, 530.8519; found, 530.8520.

5,5-Bis(3,5-dibromobenzyl)pyrimidine-2,4,6-(1H,3H,5H)-trione (3e). To a stirred solution of urea $(1.83 \mathrm{~g}, 2.79 \mathrm{mmol})$ in anhydrous DMF $(15 \mathrm{~mL})$ was added $\mathrm{NaH}(183 \mathrm{mg}, 7.6 \mathrm{mmol})$, and the resulting solution was stirred for $10 \mathrm{~min}$ before adding $2 \mathrm{e}(2.0 \mathrm{~g}, 3.05 \mathrm{mmol})$. The resulting mixture was stirred overnight. The reaction was diluted with EtOAc $(50 \mathrm{~mL})$ and washed with $10 \%$ citric acid soln $(3 \times 25$ $\mathrm{mL}), 10 \% \mathrm{NaHCO}_{3}$ soln $(2 \times 30 \mathrm{~mL})$, and brine $(30 \mathrm{~mL})$. The organic phase was dried over $\mathrm{Na}_{2} \mathrm{SO}_{4}$, filtered, and concentrated. The white solid was dissolved in $\mathrm{CHCl}_{3}(25 \mathrm{~mL})$, concentrated again, and purified by flash chromatography to afford $3 \mathrm{e}(1.52 \mathrm{~g}, 88 \%) .{ }^{1} \mathrm{H}$ NMR $\left(400 \mathrm{MHz}, \mathrm{CDCl}_{3}\right): \delta 7.82(\mathrm{NH}, \mathrm{s}, 2 \mathrm{H}), 7.58(\mathrm{t}, J=1.8 \mathrm{~Hz}, 2 \mathrm{H})$, $7.21(\mathrm{~d}, J=1.5 \mathrm{~Hz}, 4 \mathrm{H}), 3.32(\mathrm{~s}, 4 \mathrm{H}) .{ }^{13} \mathrm{C}$ NMR $\left(101 \mathrm{MHz}, \mathrm{CDCl}_{3}\right)$ : $\delta 170.0,146.4,137.7,134.2,131.5,123.6,59.9,43.4$. HRMS-ESI: $\mathrm{C}_{18} \mathrm{H}_{11}{ }^{79} \mathrm{Br}_{4} \mathrm{~N}_{2} \mathrm{O}_{3}{ }^{-}[\mathrm{M}-\mathrm{H}]^{-}$calcd, 618.7509; found, 618.7501.

5,5-Bis (3,5-bis (trifluoromethyl)benzyl)pyrimidine-2,4,6$(1 \mathrm{H}, 3 \mathrm{H}, 5 \mathrm{H})$-trione $(3 \mathrm{f})$. To a solution of urea $(1.3 \mathrm{~g}, 21.6 \mathrm{mmol})$ in 20 $\mathrm{mL}$ of anhydrous DMF was added $\mathrm{NaH}(128 \mathrm{mg}, 5.3 \mathrm{mmol})$, and the resulting solution was stirred for $10 \mathrm{~min}$ before adding $2 \mathrm{f}(1.0 \mathrm{~g}, 1.7$ $\mathrm{mmol}$ ). The resulting mixture was stirred overnight. The reaction was diluted with EtOAc $(50 \mathrm{~mL})$ and washed with $10 \%$ citric acid soln $(3$ $\times 30 \mathrm{~mL}), 10 \% \mathrm{NaHCO}_{3}$ soln $(2 \times 20 \mathrm{~mL})$, and brine $(30 \mathrm{~mL})$. The organic phase was dried over $\mathrm{Na}_{2} \mathrm{SO}_{4}$, filtered, and concentrated. The crude was purified by automated flash chromatography to afford $3 \mathbf{f}$ $(0.27 \mathrm{~g}, 27 \%)$ as a white powder. ${ }^{1} \mathrm{H}$ NMR $\left(400 \mathrm{MHz} \mathrm{CDCl}_{3}\right): \delta$ $7.82(\mathrm{NH}, \mathrm{s}, 2 \mathrm{H}), 7.73(\mathrm{~s}, 2 \mathrm{H}), 7.62-7.57(\mathrm{~m}, 4 \mathrm{H}), 3.57(\mathrm{~s}, 4 \mathrm{H}) .{ }^{13} \mathrm{C}$ NMR (101 MHz, $\left.\mathrm{CDCl}_{3}\right): \delta 169.8,146.1,136.3,132.6\left(\mathrm{q},{ }^{2} J_{\mathrm{C}, \mathrm{F}}=\right.$ $33.6 \mathrm{~Hz}), 130.4-129.7(\mathrm{~m}), 122.0\left(\mathrm{q},{ }^{1} J_{\mathrm{C}, \mathrm{F}}=272.8 \mathrm{~Hz}\right), 122.9-122.2$ (m), 59.9, 43.5. HRMS-ESI: $\mathrm{C}_{22} \mathrm{H}_{11} \mathrm{~F}_{12} \mathrm{~N}_{2} \mathrm{O}_{3}^{-}[\mathrm{M}-\mathrm{H}]^{-}$calcd, 579.0584; found, 579.0583 .

5,5-Bis(4-tert-butylbenzyl)pyrimidin-2,4,6(1H,3H,5H)-trione (3g). To a stirred solution of urea $(6.63 \mathrm{~g}, 110 \mathrm{mmol})$ at room temperature in anhydrous DMF $(20 \mathrm{~mL})$ was added $\mathrm{NaH}(660 \mathrm{mg}, 27.5 \mathrm{mmol})$, and the reaction was stirred for $5 \mathrm{~min}$. A solution of $2 \mathrm{~g}(5 \mathrm{~g}, 11$ $\mathrm{mmol})$ in anhydrous DMF $(20 \mathrm{~mL})$ was added dropwise to the reaction mixture, and the reaction was stirred overnight. The reaction mixture was diluted with EtOAc $(20 \mathrm{~mL})$ and washed with $10 \%$ citric acid $(100 \mathrm{~mL}), 10 \% \mathrm{NaHCO}_{3}$ soln $(50 \mathrm{~mL})$, brine $(50 \mathrm{~mL})$, water $(20 \mathrm{~mL})$, and brine $(2 \times 50 \mathrm{~mL})$. The organic phase was dried over $\mathrm{Na}_{2} \mathrm{SO}_{4}$, filtered, and concentrated. The crude product was purified by automated flash chromatography (heptane/EtOAc) affording 4.09 $\mathrm{g}(88 \%)$ of $3 \mathrm{~g}$ as a white powder. ${ }^{1} \mathrm{H}$ NMR $\left(400 \mathrm{MHz}, \mathrm{CD}_{3} \mathrm{OD}\right): \delta$ $7.26(\mathrm{~d}, J=7.7 \mathrm{~Hz}, 2 \mathrm{H}), 7.05(\mathrm{~d}, J=7.6 \mathrm{~Hz}, 2 \mathrm{H}), 3.31(\mathrm{~s}, 4 \mathrm{H}$, overlap $\left.\mathrm{CD}_{3} \mathrm{OD}\right), 1.24$ (s, $\left.18 \mathrm{H}\right) .{ }^{13} \mathrm{C}$ NMR (101 $\left.\mathrm{MHz}, \mathrm{CD}_{3} \mathrm{OD}\right): \delta 174.2$, $151.5^{*}, 133.5,130.4,126.4,61.4,45.0,35.3$, 31.7. *Assumed overlap of two signals. HRMS-ESI: $\mathrm{C}_{26} \mathrm{H}_{31} \mathrm{~N}_{2} \mathrm{O}_{3}^{-}[\mathrm{M}-\mathrm{H}]^{-}$calcd, 419.2340; found, 419.2335 .

5,5-Bis(3,5-di-tert-butylbenzyl)pyrimidine-2,4,6(1H,3H,5H)-trione (3h). Compound $3 \mathrm{~h}$ was provided to us by Elizaveta M. Igumnova. ${ }^{1} \mathrm{H}$ NMR $\left(400 \mathrm{MHz}, \mathrm{CDCl}_{3}\right): \delta 7.25-7.24(\mathrm{~m}, 2 \mathrm{H}), 6.96(\mathrm{~d}, J=1.8 \mathrm{~Hz}$, $4 \mathrm{H}), 3.45(\mathrm{~s}, 4 \mathrm{H}), 1.26(\mathrm{~s}, 36 \mathrm{H}) \cdot{ }^{13} \mathrm{C} \mathrm{NMR}\left(101 \mathrm{MHz}, \mathrm{CDCl}_{3}\right): \delta$ 171.5, 151.3, 133.7, 123.9, 121.3, 61.7, 45.4, 34.9, 31.5. HRMS-ESI: $\mathrm{C}_{34} \mathrm{H}_{47} \mathrm{~N}_{2} \mathrm{O}_{3}{ }^{-}[\mathrm{M}-\mathrm{H}]^{-}$calcd, 531.3592; found, 531.3592.

$\mathrm{N}$-Alkylation of Barbiturates (3) with 1,4-Dibromobutane. 1,3Bis(4-bromobutyl)-5,5-bis(4-trifluoromethylbenzyl)pyrimidine$2,4,6(1 \mathrm{H}, 3 \mathrm{H}, 5 \mathrm{H})$-trione $(4 \mathrm{a})$. To a stirred solution of $3 \mathrm{a}(1.59 \mathrm{~g}, 3.58$ $\mathrm{mmol})$ at room temperature in DMF $(15 \mathrm{~mL})$ were added $\mathrm{K}_{2} \mathrm{CO}_{3}$ $(2.00 \mathrm{~g}, 14.47 \mathrm{mmol})$ and 1,4-dibromobutane $(4.24 \mathrm{~mL}, 35.8 \mathrm{mmol})$. The reaction mixture was stirred for $48 \mathrm{~h}$, diluted with EtOAc (50 $\mathrm{mL})$, and washed with $10 \%$ citric acid soln $(3 \times 25 \mathrm{~mL}), 10 \%$ $\mathrm{NaHCO}_{3}$ soln $(2 \times 25 \mathrm{~mL})$, and brine $(25 \mathrm{~mL})$. The organic phase was dried over $\mathrm{Na}_{2} \mathrm{SO}_{4}$, filtered, and concentrated. The crude product was purified using automated flash chromatography affording $4 \mathbf{a}(2.47$ g, $96 \%)$ as a white powder. ${ }^{1} \mathrm{H}$ NMR $\left(400 \mathrm{MHz}, \mathrm{CDCl}_{3}\right): \delta 7.50(\mathrm{~d}, J$ $=7.8 \mathrm{~Hz}, 4 \mathrm{H}), 7.20(\mathrm{~d}, J=8.0 \mathrm{~Hz}, 4 \mathrm{H}), 3.61(\mathrm{t}, J=7.3 \mathrm{~Hz}, 4 \mathrm{H}), 3.51$ $(\mathrm{s}, 4 \mathrm{H}), 3.31(\mathrm{t}, J=6.5 \mathrm{~Hz}, 4 \mathrm{H}), 1.67-1.49(\mathrm{~m}, 4 \mathrm{H}), 1.39(\mathrm{p}, J=7.1$ $\mathrm{Hz}, 4 \mathrm{H}) .{ }^{13} \mathrm{C}$ NMR $\left(101 \mathrm{MHz}, \mathrm{CDCl}_{3}\right): \delta 170.2,149.3,138.8,130.4$ $\left(\mathrm{q},{ }^{2} J_{\mathrm{C}, \mathrm{F}}=32.7 \mathrm{~Hz}\right), 130.1,125.8\left(\mathrm{q},{ }^{3} J_{\mathrm{C}, \mathrm{F}}=3.7 \mathrm{~Hz}\right), 123.9\left(\mathrm{q},{ }^{1} J_{\mathrm{C}, \mathrm{F}}=\right.$ $272.2 \mathrm{~Hz}), 60.0,45.2,41.1,32.7,29.5,26.4$. HRMS-ESI: $\mathrm{C}_{28} \mathrm{H}_{28}{ }^{79} \mathrm{Br}_{2} \mathrm{~F}_{6} \mathrm{KN}_{2} \mathrm{O}_{3}{ }^{+}[\mathrm{M}+\mathrm{K}]^{+}$calcd, 751.0002; found, 751.0006 .

1,3-Bis(4-bromobutyl)-5,5-bis(naphthalen-2-yl-methyl)pyrimidine-2,4,6(1H,3H,5H)-trione (4b). To a stirred suspension of $3 \mathbf{b}(200 \mathrm{mg}, 0.49 \mathrm{mmol})$ and $\mathrm{K}_{2} \mathrm{CO}_{3}(273 \mathrm{mg}, 1.95 \mathrm{mmol})$ in $\mathrm{DMF}$ (4 mL) was added 1,4-dibromobutane $(0.57 \mathrm{~mL}, 4.9 \mathrm{mmol})$. The reaction was stirred for $18-48 \mathrm{~h}$ until completion was indicated by TLC (5\% EtOAc in $\mathrm{CHCl}_{3}$ ). The reaction mixture was diluted with EtOAc $(25 \mathrm{~mL})$, and $\mathrm{K}_{2} \mathrm{CO}_{3}$ was filtered off. The organic phase was washed with $10 \%$ citric acid solution $(30 \mathrm{~mL}), 10 \% \mathrm{NaHCO}_{3}$ soln $(30 \mathrm{~mL})$, water $(3 \times 30 \mathrm{~mL})$, and brine $(30 \mathrm{~mL})$; dried with $\mathrm{Na}_{2} \mathrm{SO}_{4}$; filtered; and concentrated. The crude product was dissolved in $\mathrm{CHCl}_{3}$ $(30 \mathrm{~mL})$ and adsorbed onto Celite before purification on a silica column using $0-5 \%$ EtOAc in $\mathrm{CHCl}_{3}$ to afford $\mathbf{4 b}(347 \mathrm{mg}, 80 \%)$ as a white powder. ${ }^{1} \mathrm{H} \mathrm{NMR}\left(400 \mathrm{MHz}, \mathrm{CDCl}_{3}\right): \delta 7.75$ (dd, $J=9.4,6.4$ $\mathrm{Hz}, 4 \mathrm{H}), 7.70(\mathrm{~d}, J=8.4 \mathrm{~Hz}, 2 \mathrm{H}), 7.57(\mathrm{~s}, 2 \mathrm{H}), 7.48-7.42(\mathrm{~m}, 4 \mathrm{H})$, $7.18(\mathrm{dd}, J=8.5,1.7 \mathrm{~Hz}, 2 \mathrm{H}), 3.68(\mathrm{~s}, 4 \mathrm{H}), 3.53(\mathrm{t}, J=6.7 \mathrm{~Hz}, 4 \mathrm{H})$, $2.99(\mathrm{t}, J=6.2 \mathrm{~Hz}, 4 \mathrm{H}), 1.35-1.19(\mathrm{~m}, 8 \mathrm{H}) .{ }^{13} \mathrm{C}$ NMR $(101 \mathrm{MHz}$, $\left.\mathrm{CDCl}_{3}\right): \delta 170.9,149.6,133.3,132.7,132.5,128.8,128.5,127.8$, $127.7,127.2,126.6,126.3,60.8,45.8,40.9,32.8,29.5$, 26.3. HRMSESI: $\mathrm{C}_{34} \mathrm{H}_{34}{ }^{79} \mathrm{Br}_{2} \mathrm{~N}_{2} \mathrm{NaO}_{3}{ }^{+}[\mathrm{M}+\mathrm{Na}]^{+}$calcd, 699.0827; found, 699.0839

1,3-Bis(4-bromobutyl)-5,5-bis(4-F-naphtalene-1-yl-methyl)pyrimidine-2,4,6(1H,3H,5H)-trione (4c). To a stirred suspension of $3 \mathrm{c}(242 \mathrm{mg}, 0.54 \mathrm{mmol})$ and $\mathrm{K}_{2} \mathrm{CO}_{3}(300 \mathrm{mg}, 2.17 \mathrm{mmol})$ in DMF $(5 \mathrm{~mL})$ was added 1,4-dibromobutane $(0.64 \mathrm{~mL}, 5.4 \mathrm{mmol})$. The reaction was stirred for $18-48 \mathrm{~h}$ until completion was indicated by TLC $\left(\mathrm{CHCl}_{3} R_{\mathrm{f}}\right.$ product: $0.74, R_{\mathrm{f}}$ starting material: 0.11$)$. The reaction mixture was diluted with EtOAc $(25 \mathrm{~mL})$, and $\mathrm{K}_{2} \mathrm{CO}_{3}$ filtered off. The organic phase was washed with $10 \%$ citric acid soln $(30 \mathrm{~mL}), 10 \% \mathrm{NaHCO}_{3}$ soln $(30 \mathrm{~mL})$, water $(3 \times 30 \mathrm{~mL})$, and brine $(30 \mathrm{~mL})$; dried with $\mathrm{Na}_{2} \mathrm{SO}_{4}$; filtered; and concentrated, yielding the crude as an oil. The crude product was dissolved in $\mathrm{CHCl}_{3}(30 \mathrm{~mL})$ and adsorbed onto Celite before purification on a silica column using $\mathrm{CHCl}_{3}$ as the mobile phase to afford $4 \mathrm{c}(237 \mathrm{mg}, 61 \%)$ as a white solid. ${ }^{1} \mathrm{H}$ NMR (400 MHz, $\mathrm{CDCl}_{3}$ ): $\delta 8.23(\mathrm{~d}, J=8.6 \mathrm{~Hz}, 2 \mathrm{H}), 8.08$ $(\mathrm{d}, J=8.3 \mathrm{~Hz}, 2 \mathrm{H}), 7.63(\mathrm{t}, J=7.7 \mathrm{~Hz}, 2 \mathrm{H}), 7.54(\mathrm{t}, J=7.6 \mathrm{~Hz}, 2 \mathrm{H})$, $7.23(\mathrm{dd}, J=8.0,5.5 \mathrm{~Hz}, 2 \mathrm{H}), 7.00(\mathrm{dd}, J=9.8,8.1 \mathrm{~Hz}, 2 \mathrm{H}), 4.06(\mathrm{~s}$, $4 \mathrm{H}), 3.33(\mathrm{t}, J=7.2 \mathrm{~Hz}, 4 \mathrm{H}), 3.05(\mathrm{t}, J=6.6 \mathrm{~Hz}, 4 \mathrm{H}), 1.34-1.12(\mathrm{~m}$, $4 \mathrm{H}), 1.08-0.90(\mathrm{~m}, 4 \mathrm{H}) .{ }^{13} \mathrm{C}$ NMR $\left(101 \mathrm{MHz}, \mathrm{CDCl}_{3}\right): \delta 170.96$, $158.5\left(\mathrm{~d},{ }^{1} J_{\mathrm{C}, \mathrm{F}}=253.3 \mathrm{~Hz}\right), 149.4,133.2\left(\mathrm{~d}, J_{\mathrm{C}, \mathrm{F}}=4.4 \mathrm{~Hz}\right), 128.0(\mathrm{~d}$, $\left.J_{\mathrm{C}, \mathrm{F}}=8.4 \mathrm{~Hz}\right), 127.4\left(\mathrm{~d}, J_{\mathrm{C}, \mathrm{F}}=4.7 \mathrm{~Hz}\right), 127.2,126.4\left(\mathrm{~d}, J_{\mathrm{C}, \mathrm{F}}=2.1 \mathrm{~Hz}\right)$, $124.8\left(\mathrm{~d}, J_{\mathrm{C}, \mathrm{F}}=2.7 \mathrm{~Hz}\right), 124.1\left(\mathrm{~d}, J_{\mathrm{C}, \mathrm{F}}=15.7 \mathrm{~Hz}\right), 121.1\left(\mathrm{~d}, J_{\mathrm{C}, \mathrm{F}}=6.0\right.$ $\mathrm{Hz}), 108.9\left(\mathrm{~d}, J_{\mathrm{C}, \mathrm{F}}=20.0 \mathrm{~Hz}\right), 60.0,40.9,40.7,32.7,29.3,25.9$. HRMS-ESI: $\mathrm{C}_{34} \mathrm{H}_{32}{ }^{79} \mathrm{Br}_{2} \mathrm{~F}_{2} \mathrm{~N}_{2} \mathrm{NaO}_{3}{ }^{+}[\mathrm{M}+\mathrm{Na}]^{+}$calcd, 735.0639; found, 735.0622 . 
5,5-Bis(4-bromo-3-chlorobenzyl)-1,3-bis(4-bromobutyl)pyrimidine-2,4,6(1H,3H,5H)-trione $(4 d)$. To a stirred suspension of $3 \mathrm{~d}(1.748 \mathrm{~g}, 3.267 \mathrm{mmol})$ and $\mathrm{K}_{2} \mathrm{CO}_{3}(1.806 \mathrm{~g}, 13.07 \mathrm{mmol})$ in DMF $(15 \mathrm{~mL})$ was added 1,4-dibromobutane $(4.46 \mathrm{~mL}, 37.3 \mathrm{mmol})$. The reaction was stirred for 14 days. The organic phase was washed with $10 \%$ citric acid soln $(30 \mathrm{~mL}), 10 \% \mathrm{NaHCO}_{3}$ soln $(30 \mathrm{~mL})$, water $(3$ $\times 30 \mathrm{~mL})$, and brine $(30 \mathrm{~mL})$; dried with $\mathrm{Na}_{2} \mathrm{SO}_{4}$; filtered; and concentrated, yielding the crude as an oil. The crude product was purified on an automated flash system silica column using DCM/ $\mathrm{MeOH}$ as the mobile phase to afford $4 \mathrm{~d}(1.78 \mathrm{mg}, 68 \%)$ as a white solid. ${ }^{1} \mathrm{H}$ NMR (400 MHz, $\left.\mathrm{CDCl}_{3}\right): \delta 7.47(\mathrm{~d}, J=8.2 \mathrm{~Hz}, 2 \mathrm{H}), 7.15$ $(\mathrm{d}, J=2.1 \mathrm{~Hz}, 2 \mathrm{H}), 6.80(\mathrm{dd}, J=8.2,2.1 \mathrm{~Hz}, 2 \mathrm{H}), 3.64(\mathrm{t}, J=7.3 \mathrm{~Hz}$, $4 \mathrm{H}), 3.41-3.28(\mathrm{~m}, 8 \mathrm{H}), 1.65-1.55(\mathrm{~m}, 4 \mathrm{H}), 1.51-1.40(\mathrm{~m}, 4 \mathrm{H})$. ${ }^{13} \mathrm{C}$ NMR $\left(101 \mathrm{MHz}, \mathrm{CDCl}_{3}\right): \delta 170.1,149.2,135.5,134.9,134.1$, 131.4, 129.1, 122.2, 59.7, 44.3, 41.2, 32.7, 29.7, 26.5. HRMS-ESI: $\mathrm{C}_{26} \mathrm{H}_{26}{ }^{79} \mathrm{Br}_{4} \mathrm{Cl}_{2} \mathrm{~N}_{2} \mathrm{NaO}_{3}{ }^{+}[\mathrm{M}+\mathrm{Na}]^{+}$calcd, 822.7946; found, 822.7960 .

1,3-Bis(4-bromobutyl)-5,5-bis(3,5-dibromobenzyl)pyrimidine$2,4,6-(1 H, 3 H, 5 H)$-trione $(4 e)$. To a stirred solution of $3 \mathbf{e}(300 \mathrm{mg}$, $0.48 \mathrm{mmol})$ in DMF $(6 \mathrm{~mL})$ was added $\mathrm{K}_{2} \mathrm{CO}_{3}(265 \mathrm{mg}, 1.92 \mathrm{mmol})$ and 1,4-dibromobutane $(0.57 \mathrm{~mL}, 4.81 \mathrm{mmol})$. The reaction was stirred for $18-48 \mathrm{~h}$ until completion was indicated by TLC (5\% EtOAc in $\mathrm{CHCl}_{3}$ ). The reaction mixture was diluted with EtOAc (25 $\mathrm{mL}$ ), and $\mathrm{K}_{2} \mathrm{CO}_{3}$ was filtered off. The organic phase was washed with $10 \%$ citric acid soln $(30 \mathrm{~mL}), 10 \% \mathrm{NaHCO}_{3}$ soln $(30 \mathrm{~mL})$, water $(3$ $\times 30 \mathrm{~mL})$, and brine $(30 \mathrm{~mL})$; dried with $\mathrm{Na}_{2} \mathrm{SO}_{4}$; filtered; and concentrated, resulting in an oil that slowly turned into white crystals. The crude product was dissolved in $\mathrm{CHCl}_{3}(30 \mathrm{~mL})$ and adsorbed onto Celite before purification on a silica column using pentane: $\mathrm{CH}_{2} \mathrm{Cl}_{2}$ (7:3 to $\left.1: 1\right)$ to afford $4 \mathrm{e}(347 \mathrm{mg}, 80 \%)$ as a white powder. ${ }^{1} \mathrm{H}$ NMR $\left(400 \mathrm{MHz}, \mathrm{CDCl}_{3}\right): \delta 7.54(\mathrm{~d}, J=1.8 \mathrm{~Hz}$, $2 \mathrm{H}), 7.14(\mathrm{~d}, J=1.7 \mathrm{~Hz}, 4 \mathrm{H}), 3.65(\mathrm{t}, J=7.4 \mathrm{~Hz}, 4 \mathrm{H}), 3.38(\mathrm{t}, J=6.7$ $\mathrm{Hz}, 4 \mathrm{H}), 3.33(\mathrm{~s}, 4 \mathrm{H}), 1.77-1.61(\mathrm{~m}, 4 \mathrm{H}), 1.58-1.43(\mathrm{~m}, 4 \mathrm{H}) .{ }^{13} \mathrm{C}$ NMR (101 MHz, $\left.\mathrm{CDCl}_{3}\right): \delta 169.9,149.1,138.4,133.9,131.3,123.4$, $59.9,44.2,41.3,32.7,30.0,26.7$. HRMS-ESI: $\mathrm{C}_{26} \mathrm{H}_{26}{ }^{79} \mathrm{Br}_{3}{ }^{81} \mathrm{Br}_{3} \mathrm{ClN}_{2} \mathrm{O}_{3}{ }^{-}[\mathrm{M}+\mathrm{Cl}]^{-}$calcd, 928.6671; found, 928.6669.

1,3-Bis(4-bromobutyl)-5,5-bis(3,5-bis(trifluoromethyl)benzyl)pyrimidine-2,4,6(1H,3H,5H)-trione (4f). To a stirred solution of $3 \mathrm{f}$ $(0.864 \mathrm{~g}, 1.57 \mathrm{mmol})$ in DMF $(20 \mathrm{~mL})$ were added $\mathrm{K}_{2} \mathrm{CO}_{3}(1.233 \mathrm{~g}$, $8.93 \mathrm{mmol})$ and 1,4-dibromobutane $(1.76 \mathrm{~mL}, 14.9 \mathrm{mmol})$. The reaction mixture was stirred for $48 \mathrm{~h}$, diluted with EtOAc $(30 \mathrm{~mL})$, and washed with water $(3 \times 20 \mathrm{~mL}), 5 \% \mathrm{LiCl}$ soln $(3 \times 20)$, and brine $(20 \mathrm{~mL})$. The crude product was purified by automated flash chromatography to afford $4 \mathrm{f}(0.64 \mathrm{~g}, 50 \%)$ as a white powder. ${ }^{1} \mathrm{H}$ NMR $\left(400 \mathrm{MHz}, \mathrm{CDCl}_{3}\right): \delta 7.79(\mathrm{~s}, 2 \mathrm{H}), 7.53(\mathrm{~s}, 4 \mathrm{H}), 3.59(\mathrm{~s}, 4 \mathrm{H})$, $3.57-3.51(\mathrm{~m}, 4 \mathrm{H}), 3.26(\mathrm{t}, J=6.8 \mathrm{~Hz}, 4 \mathrm{H}), 1.67-1.55(\mathrm{~m}, 4 \mathrm{H})$, $1.43-1.29(\mathrm{~m}, 4 \mathrm{H}) .{ }^{13} \mathrm{C}$ NMR (101 MHz, $\left.\mathrm{CDCl}_{3}\right): \delta 169.4,148.4$, $136.9,132.2\left(\mathrm{q},{ }^{2} J_{\mathrm{C}, \mathrm{F}}=33.6 \mathrm{~Hz}\right), 130.0-129.4(\mathrm{~m}), 122.9\left(\mathrm{q},{ }^{1} J_{\mathrm{C}, \mathrm{F}}=\right.$ $272.9 \mathrm{~Hz}), 122.1\left(\mathrm{p},{ }^{3} J_{\mathrm{C}, \mathrm{F}}=3.8 \mathrm{~Hz}\right), 59.7,44.3,41.1,31.7,29.6,26.1$. HRMS-ESI: $\mathrm{C}_{30} \mathrm{H}_{26}{ }^{79} \mathrm{Br}_{3} \mathrm{~F}_{12} \mathrm{~N}_{2} \mathrm{O}_{3}{ }^{-}[\mathrm{M}+\mathrm{Br}]^{-}$calcd, 926.9308; found, 926.9308.

1,3-Bis(4-bromobutyl)-5,5-bis(4-tert-butylbenzyl)pyrimidine$2,4,6(1 \mathrm{H}, 3 \mathrm{H}, 5 \mathrm{H})$-trione $(\mathbf{4 g})$. To a stirred solution of $3 \mathrm{~g}(3.88 \mathrm{~g}, 9.23$ $\mathrm{mmol})$ at room temperature in DMF $(50 \mathrm{~mL})$ were added $\mathrm{K}_{2} \mathrm{CO}_{3}$ $(5.12 \mathrm{~g}, 37 \mathrm{mmol})$ and 1,4-dibromobutane $(10.9 \mathrm{~mL}, 92.5 \mathrm{mmol})$. The reaction mixture was stirred overnight. The reaction mixture was diluted with EtOAc $(100 \mathrm{~mL})$ and washed with water $(100 \mathrm{~mL})$. The crude product was purified by automated flash chromatography, affording the product $4 \mathrm{~g}(2.60 \mathrm{~g}, 40 \%)$ as a white powder. ${ }^{1} \mathrm{H}$ NMR $\left(400 \mathrm{MHz}, \mathrm{CDCl}_{3}\right): \delta 7.22(\mathrm{~d}, J=7.8 \mathrm{~Hz}, 4 \mathrm{H}), 6.98(\mathrm{~d}, J=7.9 \mathrm{~Hz}$, $4 \mathrm{H}), 3.60(\mathrm{t}, J=6.9 \mathrm{~Hz}, 4 \mathrm{H}), 3.41(\mathrm{~s}, 4 \mathrm{H}), 3.33(\mathrm{t}, J=6.4 \mathrm{~Hz}, 4 \mathrm{H})$, $1.56(\mathrm{p}, J=7.3 \mathrm{~Hz}, 4 \mathrm{H}), 1.42(\mathrm{p}, J=7.7 \mathrm{~Hz}, 4 \mathrm{H}), 1.25(\mathrm{~s}, 18 \mathrm{H}) .{ }^{13} \mathrm{C}$ NMR $\left(101 \mathrm{MHz}, \mathrm{CDCl}_{3}\right): \delta 170.9,150.7,149.9,131.9,129.2,125.5$, $60.7,45.0,40.7,34.5,32.9,31.4,29.5, \quad 26.2$. HRMS-ESI: $\mathrm{C}_{34} \mathrm{H}_{46}{ }^{79} \mathrm{Br}_{2} \mathrm{~N}_{2} \mathrm{NaO}_{3}{ }^{+}[\mathrm{M}+\mathrm{Na}]^{+}$calcd, 711.1774; found, 711.1773.

1,3-Bis(4-bromobutyl)-5,5-bis(3,5-di-tert-butylbenzyl)pyrimidine-2,4,6(1H,3H,5H)-trione $(4 \mathrm{~h})$. To a stirred solution of $3 \mathrm{~h}$ $(0.86 \mathrm{~g}, 1.62 \mathrm{mmol})$ in DMF was added $\mathrm{K}_{2} \mathrm{CO}_{3}(1.2 \mathrm{~g}, 8.9 \mathrm{mmol})$. The reaction mixture was stirred for $5 \mathrm{~min}$ before addition of 1,4- dibromobutane $(1.76 \mathrm{~mL}, 14.8 \mathrm{mmol})$. The reaction was stirred for $18-48 \mathrm{~h}$ until completion was indicated by TLC (5\% EtOAc in $\left.\mathrm{CHCl}_{3}\right)$. The reaction mixture was diluted with EtOAc $(15 \mathrm{~mL})$, and $\mathrm{K}_{2} \mathrm{CO}_{3}$ was filtered off. The organic phase was washed with $10 \%$ citric acid soln $(30 \mathrm{~mL}), 10 \% \mathrm{NaHCO}_{3}$ soln $(30 \mathrm{~mL})$, water $(3 \times 30 \mathrm{~mL})$, and brine $(30 \mathrm{~mL})$; dried with $\mathrm{Na}_{2} \mathrm{SO}_{4}$; filtered; and concentrated. The crude was purified by automated flash chromatography to afford 4h $(0.64 \mathrm{~g}, 74 \%) .{ }^{1} \mathrm{H}$ NMR $\left(400 \mathrm{MHz}, \mathrm{CDCl}_{3}\right): \delta 7.26(\mathrm{t}, J=1.9 \mathrm{~Hz}$, $2 \mathrm{H}), 6.89(\mathrm{~d}, J=1.8 \mathrm{~Hz}, 4 \mathrm{H}), 3.59^{*}(\mathrm{t}, J=7.5 \mathrm{~Hz}, 4 \mathrm{H}), 3.46(\mathrm{~s}, 4 \mathrm{H})$, $3.23(\mathrm{t}, J=6.7 \mathrm{~Hz}, 4 \mathrm{H}), 1.51(\mathrm{p}, J=6.8 \mathrm{~Hz}, 4 \mathrm{H}), 1.35-1.23(\mathrm{~m}$, $40 \mathrm{H}) .{ }^{13} \mathrm{C}$ NMR $\left(101 \mathrm{MHz}, \mathrm{CDCl}_{3}\right): \delta 171.0,151.1,150.0,134.4$, 123.7, 121.5, 60.5, 46.5, 40.9, 34.8, 32.4, 31.6, 29.7, 26.5. *Distorted triplet. HRMS-ESI: $\mathrm{C}_{42} \mathrm{H}_{62}{ }^{79} \mathrm{Br}_{2} \mathrm{KN}_{2} \mathrm{O}_{3}{ }^{+}[\mathrm{M}+\mathrm{K}]^{+}$calcd, 839.2759; found, 839.2725.

Transformation to Azides (5). 1,3-Bis(4-azidobutyl)-5,5-bis(4trifluoromethylbenzyl)pyrimidine-2,4,6(1H,3H,5H)-trione (5a). To a stirred solution of $4 \mathrm{a}(2.40 \mathrm{~g}, 3.35 \mathrm{mmol})$ in $5 \mathrm{~mL}$ of DMF was added $\mathrm{NaN}_{3}(762 \mathrm{mg}, 11.7 \mathrm{mmol}$ ) and stirred for $18 \mathrm{~h}$. The reaction mixture was diluted with EtOAc $(30 \mathrm{~mL})$ and washed with water $(3 \times 50$ $\mathrm{mL}$ ). The organic phase was dried over $\mathrm{Na}_{2} \mathrm{SO}_{4}$, filtered, and concentrated to afford the crude product $\mathbf{5 a}$ as white crystals $(1.91 \mathrm{~g}$, 89\%). ${ }^{1} \mathrm{H}$ NMR $\left(400 \mathrm{MHz}, \mathrm{CDCl}_{3}\right): \delta 7.49(\mathrm{~d}, J=7.8 \mathrm{~Hz}, 4 \mathrm{H}), 7.19$ $(\mathrm{d}, J=7.8 \mathrm{~Hz}, 4 \mathrm{H}), 3.67-3.58(\mathrm{~m}, 4 \mathrm{H}), 3.51(\mathrm{~s}, 4 \mathrm{H}), 3.27-3.15(\mathrm{~m}$,

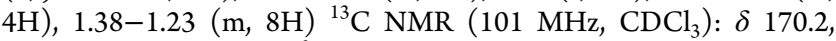
$149.3,138.8,130.4\left(\mathrm{q},{ }^{2} J_{\mathrm{C}, \mathrm{F}}=32.7 \mathrm{~Hz}\right), 130.1,126.0-125.6(\mathrm{~m})$, $123.9\left(\mathrm{q},{ }^{1} J_{\mathrm{C}, \mathrm{F}}=272.2 \mathrm{~Hz}\right), 59.9,50.8,45.1,41.4,26.0,24.9$. HRMSESI: $\mathrm{C}_{28} \mathrm{H}_{28} \mathrm{~F}_{6} \mathrm{~N}_{8} \mathrm{O}_{3} \mathrm{Na}^{+}[\mathrm{M}+\mathrm{Na}]^{+}$calcd, 661.2079; found, 661.2074.

1,3-Bis(4-azidobutyl)-5,5-bis (naphthalen-2-yl)pyrimidine-2,4,6$(1 \mathrm{H}, 3 \mathrm{H}, 5 \mathrm{H})$-trione $(\mathbf{5 b})$. To a stirred solution of $\mathbf{4 b}(509 \mathrm{mg}, 0.75$ $\mathrm{mmol})$ in DMF $(3 \mathrm{~mL})$ was added $\mathrm{NaN}_{3}(146 \mathrm{mg}, 2.25 \mathrm{mmol})$. The reaction was stirred overnight until completion was indicated by TLC ( $5 \% \mathrm{EtOAc}$ in $\mathrm{CHCl}_{3}$ ). The reaction mixture was diluted with EtOAc $(20 \mathrm{~mL})$ and washed with water $(3 \times 20 \mathrm{~mL})$. The organic phase was dried over $\mathrm{Na}_{2} \mathrm{SO}_{4}$, filtered, and concentrated. The crude product was dissolved in $\mathrm{CHCl}_{3}$ and adsorbed onto Celite before purification on a silica column using $0-5 \%$ EtOAc in $\mathrm{CHCl}_{3}$ to afford $\mathbf{5 b}(194 \mathrm{mg}$, 91\%). ${ }^{1} \mathrm{H}$ NMR $\left(400 \mathrm{MHz}, \mathrm{CDCl}_{3}\right): \delta 7.80-7.71(\mathrm{~m}, 4 \mathrm{H}), 7.68(\mathrm{~d}, J$ $=8.4 \mathrm{~Hz}, 2 \mathrm{H}), 7.57(\mathrm{~s}, 2 \mathrm{H}), 7.51-7.41(\mathrm{~m}, 4 \mathrm{H}), 7.17(\mathrm{~d}, J=8.4 \mathrm{~Hz}$, $2 \mathrm{H}), 3.68(\mathrm{~s}, 4 \mathrm{H}), 3.52(\mathrm{t}, J=7.0 \mathrm{~Hz}, 4 \mathrm{H}), 2.85(\mathrm{t}, J=6.6 \mathrm{~Hz}, 4 \mathrm{H})$, $1.14(\mathrm{p}, J=7.4 \mathrm{~Hz}, 4 \mathrm{H}), 1.02(\mathrm{p}, J=7.0 \mathrm{~Hz}, 4 \mathrm{H}) .{ }^{13} \mathrm{C}$ NMR $(101$ $\left.\mathrm{MHz}, \mathrm{CDCl}_{3}\right): \delta 170.9,149.6,133.4,132.7,132.5,128.8,128.5$, $127.8,127.7,127.2,126.6,126.3,60.8,50.7,45.8,41.2,25.8,24.9$. HRMS-ESI: $\mathrm{C}_{34} \mathrm{H}_{34} \mathrm{~N}_{8} \mathrm{NaO}_{3}{ }^{+}[\mathrm{M}+\mathrm{Na}]^{+}$calcd, 625.2646; found, 625.2647.

1,3-Bis(4-azidobutyl)-5,5-bis((4-fluoronaphthalen-1-yl)methyl)pyrimidine-2,4,6-(1H,3H,5H)-trione (5c). To a stirred solution of $4 \mathrm{c}$ (166 mg, $0.23 \mathrm{mmol})$ in DMF $(3 \mathrm{~mL})$ was added $\mathrm{NaN}_{3}(45 \mathrm{mg}, 0.69$ $\mathrm{mmol})$. The reaction was stirred overnight until completion was indicated by TLC $\left(\mathrm{CHCl}_{3}\right)$. Then, the reaction mixture was diluted with EtOAc $(20 \mathrm{~mL})$ and washed with water $(3 \times 30 \mathrm{~mL})$ and brine $(30 \mathrm{~mL})$. The organic phase was dried over $\mathrm{Na}_{2} \mathrm{SO}_{4}$, filtered, and concentrated to afford 5c (142 mg, 95\%). ${ }^{1} \mathrm{H}$ NMR (400 MHz, $\left.\mathrm{CDCl}_{3}\right): \delta 8.23(\mathrm{~d}, J=8.6 \mathrm{~Hz}, 2 \mathrm{H}), 8.08(\mathrm{~d}, J=8.3 \mathrm{~Hz}, 2 \mathrm{H}), 7.62(\mathrm{t}, J$ $=7.6 \mathrm{~Hz}, 2 \mathrm{H}), 7.54(\mathrm{t}, J=7.5 \mathrm{~Hz}, 2 \mathrm{H}), 7.22(\mathrm{t}, J=6.6 \mathrm{~Hz}, 2 \mathrm{H}), 6.98$ $(\mathrm{t}, J=9.0 \mathrm{~Hz}, 2 \mathrm{H}), 4.06(\mathrm{~s}, 4 \mathrm{H}), 3.33(\mathrm{t}, J=6.8 \mathrm{~Hz}, 4 \mathrm{H}), 2.94(\mathrm{t}, J=$ $6.4 \mathrm{~Hz}, 4 \mathrm{H}), 1.10-0.74(\mathrm{~m}, 8 \mathrm{H}) .{ }^{13} \mathrm{C}$ NMR $\left(101 \mathrm{MHz}, \mathrm{CDCl}_{3}\right): \delta$ $170.9,158.5\left(\mathrm{~d},{ }^{1} J_{\mathrm{C}, \mathrm{F}}=253.4 \mathrm{~Hz}\right), 149.4,133.2\left(\mathrm{~d}, J_{\mathrm{C}, \mathrm{F}}=4.4 \mathrm{~Hz}\right)$, $127.9\left(\mathrm{~d}, J_{\mathrm{C}, \mathrm{F}}=8.5 \mathrm{~Hz}\right), 127.4\left(\mathrm{~d}, J_{\mathrm{C}, \mathrm{F}}=4.6 \mathrm{~Hz}\right), 127.2,126.4\left(\mathrm{~d}, J_{\mathrm{C}, \mathrm{F}}\right.$ $=1.9 \mathrm{~Hz}), 124.8\left(\mathrm{~d}, J_{\mathrm{C}, \mathrm{F}}=2.6 \mathrm{~Hz}\right), 124.1\left(\mathrm{~d}, J_{\mathrm{C}, \mathrm{F}}=15.7 \mathrm{~Hz}\right), 121.1$ $\left(\mathrm{d}, J_{\mathrm{C}, \mathrm{F}}=6.1 \mathrm{~Hz}\right), 108.8\left(\mathrm{~d}, J_{\mathrm{C}, \mathrm{F}}=20.0 \mathrm{~Hz}\right), 60.0,50.7,41.1,40.7$, 25.6, 24.4. HRMS-ESI: $\mathrm{C}_{34} \mathrm{H}_{32} \mathrm{ClF}_{2} \mathrm{~N}_{8} \mathrm{O}_{3}^{-}[\mathrm{M}+\mathrm{Cl}]^{-}$calcd, 673.2259; found, 673.2259 .

1,3-Bis(4-azidobutyl)-5,5-bis(4-bromo-3-chlorobenzyl)pyrimidine-2,4,6(1H,3H,5H)-trione (5d). To a stirred solution of $4 \mathrm{~d}$ $(1.28 \mathrm{~g}, 1.58 \mathrm{mmol})$ in DMF $(20 \mathrm{~mL})$ was added $\mathrm{NaN}_{3}(0.29 \mathrm{~g}, 4.75$ $\mathrm{mmol})$. The reaction was stirred overnight until completion was indicated by TLC $\left(5 \% \mathrm{EtOAc}\right.$ in $\left.\mathrm{CHCl}_{3}\right)$. Then, the reaction mixture was diluted with EtOAc $(25 \mathrm{~mL})$ and washed with water $(2 \times 20$ $\mathrm{mL})$. The organic phase was dried over $\mathrm{Na}_{2} \mathrm{SO}_{4}$, filtered, and concentrated to yield the crude product $5 \mathbf{d}(1.153 \mathrm{~g}, 98 \%)$. The crude 
product was used without further purification. ${ }^{1} \mathrm{H}$ NMR $(400 \mathrm{MHz}$, $\left.\mathrm{CDCl}_{3}\right): \delta 7.46(\mathrm{~d}, J=8.2 \mathrm{~Hz}, 2 \mathrm{H}), 7.15(\mathrm{~d}, J=2.0 \mathrm{~Hz}, 2 \mathrm{H}), 6.80$ $(\mathrm{dd}, J=8.2,2.1 \mathrm{~Hz}, 2 \mathrm{H}), 3.63(\mathrm{t}, J=6.7 \mathrm{~Hz}, 4 \mathrm{H}), 3.35(\mathrm{~s}, 4 \mathrm{H}), 3.30-$ $3.21(\mathrm{~m}, 4 \mathrm{H}), 1.36(\mathrm{~h}, J=3.2 \mathrm{~Hz}, 8 \mathrm{H}) .{ }^{13} \mathrm{C}$ NMR $(101 \mathrm{MHz}$, $\left.\mathrm{CDCl}_{3}\right): \delta 170.1,149.2,135.5,134.9,134.1,131.4,129.1,122.2,59.7$, 50.9, 44.3, 41.5, 26.1, 25.1. HRMS-ESI: $\mathrm{C}_{26} \mathrm{H}_{26}{ }^{79} \mathrm{Br}_{2} \mathrm{Cl}_{2} \mathrm{~N}_{8} \mathrm{NaO}_{3}{ }^{+}[\mathrm{M}$ $+\mathrm{Na}]^{+}$calcd, 748.9764; found, 748.9777.

1,3-Bis(4-azidobutyl)-5,5-bis(3,5-dibromobenzyl)pyrimidine$2,4,6-(1 H, 3 H, 5 H)$-trione $(5 e)$. To a stirred solution of $4 \mathrm{e}(239 \mathrm{mg}$, $0.26 \mathrm{mmol})$ in DMF $(3 \mathrm{~mL})$ was added $\mathrm{NaN}_{3}(52 \mathrm{mg}, 0.8 \mathrm{mmol})$. The reaction was stirred overnight until completion was indicated by TLC ( $5 \%$ EtOAc in $\mathrm{CHCl}_{3}$ ). Then, the reaction mixture was diluted with EtOAc $(15 \mathrm{~mL})$ and washed with water $(2 \times 20 \mathrm{~mL})$. The organic phase was dried over $\mathrm{Na}_{2} \mathrm{SO}_{4}$, filtered, and concentrated. The crude product was dissolved in $\mathrm{CHCl}_{3}$ and adsorbed onto Celite before purification on a silica column using $0-5 \% \mathrm{EtOAc}$ in $\mathrm{CHCl}_{3}$ to afford 5e (194 mg, 91\%). ${ }^{1} \mathrm{H}$ NMR (400 $\left.\mathrm{MHz}, \mathrm{CDCl}_{3}\right): \delta 7.54(\mathrm{~s}$, $2 \mathrm{H}), 7.14(\mathrm{~s}, 4 \mathrm{H}), 3.73-3.58(\mathrm{~m}, 4 \mathrm{H}), 3.33(\mathrm{~s}, 4 \mathrm{H}), 3.31-3.22(\mathrm{~m}$,

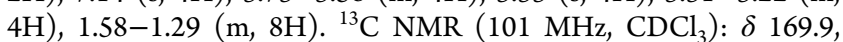
149.1, 138.4, 133.8, 131.4, 123.3, 59.9, 50.9, 44.2, 41.6, 26.1, 25.3. HRMS-ESI: $\mathrm{C}_{26} \mathrm{H}_{26}{ }^{79} \mathrm{Br}_{4} \mathrm{ClN}_{8} \mathrm{O}_{3}{ }^{-}[\mathrm{M}+\mathrm{Cl}]^{-}$calcd, 848.8555; found, 848.8564 .

1,3-Bis(4-azidobutyl)-5,5-bis(3,5-bis(trifluoromethyl)benzyl)pyrimidine-2,4,6-(1H,3H,5H)-trione (5f). To a stirred solution of $\mathbf{4 f}$ (101 mg, $0.12 \mathrm{mmol})$ in DMF $(1 \mathrm{~mL})$ was added $\mathrm{NaN}_{3}(23 \mathrm{mg}, 0.35$ $\mathrm{mmol})$. The reaction was stirred overnight. When full conversion was reached according to MS analysis, the reaction mixture was diluted with EtOAc $(15 \mathrm{~mL})$ and washed with water $(3 \times 20 \mathrm{~mL})$. The organic phase was dried over $\mathrm{Na}_{2} \mathrm{SO}_{4}$, filtered, and concentrated to afford the crude of $\mathbf{5 f}(63 \mathrm{mg}, 68 \%)$ as a white powder. ${ }^{1} \mathrm{H}$ NMR (400 $\left.\mathrm{MHz}, \mathrm{CDCl}_{3}\right): \delta 7.78(\mathrm{~s}, 2 \mathrm{H}), 7.53(\mathrm{~s}, 4 \mathrm{H}), 3.59(\mathrm{~s}, 4 \mathrm{H}), 3.57-3.48$ $(\mathrm{m}, 4 \mathrm{H}), 3.19(\mathrm{t}, J=6.7 \mathrm{~Hz}, 4 \mathrm{H}), 1.42-1.31(\mathrm{~m}, 4 \mathrm{H}), 1.31-1.20(\mathrm{~m}$, $4 \mathrm{H}) .{ }^{13} \mathrm{C}$ NMR $\left(101 \mathrm{MHz}, \mathrm{CDCl}_{3}\right): \delta 169.6,148.6,137.0,132.3(\mathrm{q}$, $\left.{ }^{2} J_{\mathrm{C}, \mathrm{F}}=33.6 \mathrm{~Hz}\right), 129.9,123.0\left(\mathrm{q},{ }^{3} J_{\mathrm{C}, \mathrm{F}}=272.9 \mathrm{~Hz}\right), 122.8-121.9(\mathrm{~m})$, 59.8, 50.6, 44.5, 41.6, 26.0, 24.9. HRMS-ESI: $\mathrm{C}_{30} \mathrm{H}_{26} \mathrm{ClF}_{12} \mathrm{~N}_{8} \mathrm{O}_{3}^{-}[\mathrm{M}$ $+\mathrm{Cl}]^{-}$calcd, 809.1630; found, 809.1622.

1,3-Bis(4-azidobutyl)-5,5-bis(4-tert-butylbenzyl)pyrimidine-2,4,6$(1 \mathrm{H}, 3 \mathrm{H}, 5 \mathrm{H})$-trione $(5 \mathrm{~g})$. To a stirred solution of bromide $4 \mathrm{~g}(2.40 \mathrm{~g}$, $3.47 \mathrm{mmol})$ in DMF $(15 \mathrm{~mL})$ was added $\mathrm{NaN}_{3}(678 \mathrm{mg}, 10.4 \mathrm{mmol})$ and stirred for $18 \mathrm{~h}$. The reaction mixture was diluted with EtOAc (50 $\mathrm{mL})$ and washed with water $(4 \times 50 \mathrm{~mL})$. The organic phase was dried over $\mathrm{Na}_{2} \mathrm{SO}_{4}$, filtered, and concentrated. The crude product $5 \mathrm{~g}$ was isolated as a clear oil $(2.16 \mathrm{~g}, 100 \%) .{ }^{1} \mathrm{H}$ NMR $(400 \mathrm{MHz}$, $\left.\mathrm{CDCl}_{3}\right): \delta 7.20(\mathrm{~d}, J=7.7 \mathrm{~Hz}, 4 \mathrm{H}), 6.97(\mathrm{~d}, J=7.8 \mathrm{~Hz}, 4 \mathrm{H}), 3.59(\mathrm{~s}$, $4 \mathrm{H}), 3.40(\mathrm{~s}, 4 \mathrm{H}), 3.21(\mathrm{~s}, 4 \mathrm{H}), 1.37-1.28(\mathrm{~m}, 8 \mathrm{H}), 1.24(\mathrm{~s}, 18 \mathrm{H})$. ${ }^{13} \mathrm{C}$ NMR $\left(101 \mathrm{MHz}, \mathrm{CDCl}_{3}\right): \delta 171.0,150.8,150.0,132.0,129.3$, 125.5, 60.7, 50.9, 45.1, 41.1, 34.6, 31.4, 26.0, 24.8. HRMS-ESI: $\mathrm{C}_{34} \mathrm{H}_{46} \mathrm{~N}_{8} \mathrm{O}_{3} \mathrm{Na}^{+}[\mathrm{M}+\mathrm{Na}]^{+}$calcd, 637.3577; found, 637.3583 .

1,3-Bis(4-azidobutyl)-5,5-bis(3,5-di-tert-butylbenzyl)pyrimidine$2,4,6-(1 H, 3 H, 5 H)$-trione (5h). To a stirred solution of $4 \mathbf{h}(630 \mathrm{mg}$, $0.78 \mathrm{mmol})$ in DMF $(10 \mathrm{~mL})$ was added $\mathrm{NaN}_{3}(140 \mathrm{mg}, 2.15 \mathrm{mmol})$. The reaction was stirred overnight. When full conversion was reached according to MS analysis, the reaction mixture was diluted with EtOAc $(50 \mathrm{~mL})$ and washed with water $4 \times 50 \mathrm{~mL}$. The organic phase was dried over $\mathrm{Na}_{2} \mathrm{SO}_{4}$, filtered, and concentrated, affording the crude product $5 \mathrm{~h}(463 \mathrm{mg}, 80 \%) .{ }^{1} \mathrm{H} \mathrm{NMR}\left(400 \mathrm{MHz} \mathrm{CDCl}_{3}\right): \delta$ $7.25(\mathrm{t}, J=1.9 \mathrm{~Hz}, 2 \mathrm{H}), 6.87(\mathrm{~d}, J=1.7 \mathrm{~Hz}, 4 \mathrm{H}), 3.56(\mathrm{t}, J=7.2 \mathrm{~Hz}$, $4 \mathrm{H}), 3.45(\mathrm{~s}, 4 \mathrm{H}), 3.14(\mathrm{t}, J=6.5 \mathrm{~Hz}, 4 \mathrm{H}), 1.25(\mathrm{~s}, 44 \mathrm{H}) .{ }^{13} \mathrm{C} \mathrm{NMR}$ $\left(101 \mathrm{MHz}, \mathrm{CDCl}_{3}\right): \delta 171.1,151.1,150.0,134.4,123.8,121.6,60.6$, 50.8, 46.5, 41.3, 34.8, 31.6, 25.9, 25.1. HRMS-ESI: $\mathrm{C}_{42} \mathrm{H}_{62} \mathrm{~N}_{8} \mathrm{NaO}_{3}{ }^{+}$ $[\mathrm{M}+\mathrm{Na}]^{+}$calcd, 749.4838; found, 749.4838 .

Reduction of Azides (5) to Amines (6). 1,3-Bis(4-aminobutyl)5,5-bis(4-(trifluoromethyl)benzyl)pyrimidin-2,4,6(1H,3H,5H)-trione (6a). To a stirred solution of $5 \mathrm{a}(1.86 \mathrm{~g}, 2.90 \mathrm{mmol})$ and $\mathrm{Et}_{3} \mathrm{~N}(0.96$ $\mathrm{mL}, 6.89 \mathrm{mmol})$ in $i$-PrOH/THF $(1: 1,10 \mathrm{~mL})$ was added 1,3propanedithiol $(0.1 \mathrm{~mL}, 0.99 \mathrm{mmol})$. The mixture was stirred for 5 min before addition of $\mathrm{NaBH}_{4}(316 \mathrm{mg}, 8.35 \mathrm{mmol})$. After a $48 \mathrm{~h}$ reaction time, $\mathrm{Boc}_{2} \mathrm{O}(1.75 \mathrm{~g}, 8.02 \mathrm{mmol})$ and $\mathrm{K}_{2} \mathrm{CO}_{3}(1.91 \mathrm{~g}, 13.8$ $\mathrm{mmol}$ ) were added, and the reaction was stirred for $18 \mathrm{~h}$ and evaporated before adding EtOAc $(20 \mathrm{~mL})$ and water $(15 \mathrm{~mL})$ and stirring for $1 \mathrm{~h}$. The organic phase was washed with water $(3 \times 15$ $\mathrm{mL})$ and brine $(15 \mathrm{~mL})$ and concentrated. The resulting crude was purified by automated flash chromatography and evaporated. The Boc-protected intermediate was deprotected with TFA $(2 \mathrm{~mL}, 26$ $\mathrm{mmol})$ in $\mathrm{CH}_{2} \mathrm{Cl}_{2}(5 \mathrm{~mL})$ for $18 \mathrm{~h}$. The reaction mixture was concentrated, and the crude product was purified by RP automated flash chromatography and lyophilized to afford $6 a(160 \mathrm{mg}, 7 \%)$ as the TFA salt. ${ }^{1} \mathrm{H}$ NMR $\left(400 \mathrm{MHz}, \mathrm{CD}_{3} \mathrm{OD}\right): \delta 7.58(\mathrm{~d}, J=8.1 \mathrm{~Hz}$, $4 \mathrm{H}), 7.28(\mathrm{~d}, J=8.1 \mathrm{~Hz}, 4 \mathrm{H}), 3.71-3.58(\mathrm{~m}, 4 \mathrm{H}), 3.57(\mathrm{~s}, 4 \mathrm{H})$, $2.96-2.75(\mathrm{~m}, 4 \mathrm{H}), 1.42(\mathrm{p}, J=7.3 \mathrm{~Hz}, 4 \mathrm{H}), 1.30(\mathrm{p}, J=7.3 \mathrm{~Hz}$, $4 \mathrm{H}) .{ }^{13} \mathrm{C}$ NMR (101 MHz, CD $\left.\mathrm{OD}\right): \delta 171.4,162.9\left(\mathrm{q},{ }^{2} J_{\mathrm{C}, \mathrm{F}}=34.7\right.$ $\mathrm{Hz}, \mathrm{TFA}), 150.7,140.9,131.5,131.0\left(\mathrm{q},{ }^{2} J_{\mathrm{C}, \mathrm{F}}=32.6 \mathrm{~Hz}\right), 126.6(\mathrm{q}$, $\left.{ }^{1} J_{\mathrm{C}, \mathrm{F}}=3.8 \mathrm{~Hz}\right), 125.5\left(\mathrm{q},{ }^{3} J_{\mathrm{C}, \mathrm{F}}=272.3 \mathrm{~Hz}\right), 118.2\left(\mathrm{q},{ }^{1} J_{\mathrm{C}, \mathrm{F}}=292.5 \mathrm{~Hz}\right.$, TFA), 61.1, 45.8, 42.0, 40.0, 25.6 (overlap, two carbons). HRMS-ESI: $\mathrm{C}_{28} \mathrm{H}_{33} \mathrm{~F}_{6} \mathrm{~N}_{4} \mathrm{O}_{3}{ }^{+}[\mathrm{M}+\mathrm{H}]^{+}$calcd, 587.2452; found, 587.2460.

1,3-Bis(4-aminobutyl)-5,5-bis(naphthalen-2-yl-methyl)pyrimidin-2,4,6(1H,3H,5H)-trione (6b). To a stirred solution of $\mathbf{5 b}$ (438 mg, $0.73 \mathrm{mmol})$ and $\mathrm{Et}_{3} \mathrm{~N}(0.22 \mathrm{~mL}, 1.59 \mathrm{mmol})$ in $i-\mathrm{PrOH} /$ THF (1:1, $4 \mathrm{~mL})$ was added 1,3-propanedithiol $(0.1 \mathrm{~mL}, 0.99 \mathrm{mmol})$. The mixture was stirred for $5 \mathrm{~min}$ before addition of $\mathrm{NaBH}_{4}(68 \mathrm{mg}$, $1.81 \mathrm{mmol})$. After a $72 \mathrm{~h}$ reaction time, $\mathrm{Boc}_{2} \mathrm{O}(333 \mathrm{mg}, 1.53 \mathrm{mmol})$ and $\mathrm{NaHCO}_{3}(244 \mathrm{mg}, 2.90 \mathrm{mmol})$ were added, and the reaction was stirred for $18 \mathrm{~h}$ before being filtered through a pad of Celite and concentrated. The resulting crude was purified by automated flash chromatography and evaporated. The Boc-protected intermediate $(305 \mathrm{mg})$ was deprotected with TFA $(2 \mathrm{~mL}, 26.1 \mathrm{mmol})$ in $\mathrm{CH}_{2} \mathrm{Cl}_{2}$ $(5 \mathrm{~mL})$ overnight. When MS analysis showed full deprotection, the reaction mixture was concentrated, and the crude product was purified by RP automated flash chromatography and lyophilized to afford $\mathbf{6 b}(287 \mathrm{mg}, 90 \%)$ as the TFA salt. ${ }^{1} \mathrm{H}$ NMR $(400 \mathrm{MHz}$, $\left.\mathrm{CD}_{3} \mathrm{OD}\right): \delta 7.90-7.68(\mathrm{~m}, 6 \mathrm{H}), 7.60(\mathrm{~s}, 2 \mathrm{H}), 7.52-7.43(\mathrm{~m}, 4 \mathrm{H})$, $7.19(\mathrm{~d}, J=8.3 \mathrm{~Hz}, 2 \mathrm{H}), 3.70(\mathrm{~s}, 4 \mathrm{H}), 3.59-3.50(\mathrm{~m}, 4 \mathrm{H}), 2.56-2.37$ $(\mathrm{m}, 4 \mathrm{H}), 1.30-0.96(\mathrm{~m}, 8 \mathrm{H}) .{ }^{13} \mathrm{C}$ NMR $\left(101 \mathrm{MHz}, \mathrm{CD}_{3} \mathrm{OD}\right): \delta$ $172.2,162.8$ (q, $J=35.2 \mathrm{~Hz}$, TFA), 151.0, 134.7, 134.1, 134.0, 129.9, $129.4,128.8,128.7,128.2,127.6,127.3,118.1$ (d, $J=292.3 \mathrm{~Hz}$, TFA), 62.0, 46.6, 41.7, 39.8, 25.6, 25.5. HRMS-ESI: $\mathrm{C}_{34} \mathrm{H}_{39} \mathrm{~N}_{4} \mathrm{O}_{3}{ }^{+}[\mathrm{M}+\mathrm{H}]^{+}$ calcd, 551.3017; found, 551.3020.

1,3-Bis(4-aminobutyl)-5,5-bis((4-fluoronaphthalen-1-yl)methyl)pyrimidin-2,4,6(1H,3H,5H)-trione (6c). To a stirred solution of $5 \mathrm{c}$ $(67 \mathrm{mg}, 0.105 \mathrm{mmol})$ and $\mathrm{Et}_{3} \mathrm{~N}(0.03 \mathrm{~mL}, 0.21 \mathrm{mmol})$ in $i-\mathrm{PrOH} /$ THF (1:1, $4 \mathrm{~mL})$ was added 1,3-propanedithiol $(0.1 \mathrm{~mL}, 0.99 \mathrm{mmol})$. The mixture was stirred for $5 \mathrm{~min}$ before addition of $\mathrm{NaBH}_{4}(8 \mathrm{mg}$, $0.21 \mathrm{mmol})$. After a $72 \mathrm{~h}$ reaction time, $\mathrm{Boc}_{2} \mathrm{O}(48 \mathrm{mg}, 0.22 \mathrm{mmol})$ and $\mathrm{NaHCO}_{3}(35 \mathrm{mg}, 0.42 \mathrm{mmol}$ ) were added, and the reaction was stirred for $18 \mathrm{~h}$ before being filtered through a pad of Celite and concentrated. The resulting crude was purified by automated flash chromatography and evaporated. The Boc-protected intermediate (72 $\mathrm{mg})$ was deprotected with TFA $(0.2 \mathrm{~mL}, 2.61 \mathrm{mmol})$ in $\mathrm{CH}_{2} \mathrm{Cl}_{2}(5$ $\mathrm{mL}$ ) overnight. When MS analysis showed full deprotection, the reaction mixture was concentrated, and the crude product was purified by RP automated flash chromatography and lyophilized to yield $6 \mathrm{c}(82 \mathrm{mg}, 89 \%)$ as the TFA salt. ${ }^{1} \mathrm{H}$ NMR $(400 \mathrm{MHz}$, $\left.\mathrm{CD}_{3} \mathrm{OD}\right): \delta 8.34(\mathrm{~d}, J=7.9 \mathrm{~Hz}, 2 \mathrm{H}), 8.07(\mathrm{~d}, J=7.7 \mathrm{~Hz}, 2 \mathrm{H}), 7.74-$ $7.53(\mathrm{~m}, 4 \mathrm{H}), 7.38-7.19(\mathrm{~m}, 2 \mathrm{H}), 7.08(\mathrm{t}, J=8.9 \mathrm{~Hz}, 2 \mathrm{H}), 4.13(\mathrm{~s}$, $4 \mathrm{H}), 3.39-3.33(\mathrm{~m}, 4 \mathrm{H}), 2.60(\mathrm{t}, J=6.8 \mathrm{~Hz}, 4 \mathrm{H}), 1.20-1.00(\mathrm{~m}$, $4 \mathrm{H}), 0.94-0.71(\mathrm{~m}, 4 \mathrm{H}) .{ }^{13} \mathrm{C}$ NMR $\left(101 \mathrm{MHz}, \mathrm{CDCl}_{3}\right): \delta 172.2$, $163.11\left(\mathrm{q},{ }^{2} J_{\mathrm{C}, \mathrm{F}}=34.1 \mathrm{~Hz}, \mathrm{TFA}\right), 159.6\left(\mathrm{~d},{ }^{1} J_{\mathrm{C}, \mathrm{F}}=251.5 \mathrm{~Hz}\right), 150.8$, $134.5\left(\mathrm{~d}, J_{\mathrm{C}, \mathrm{F}}=4.4 \mathrm{~Hz}\right), 129.3\left(\mathrm{~d}, J_{\mathrm{C}, \mathrm{F}}=4.5 \mathrm{~Hz}\right), 128.4\left(\mathrm{~d}, J_{\mathrm{C}, \mathrm{F}}=8.5\right.$ $\mathrm{Hz}), 128.2,127.6\left(\mathrm{~d}, J_{\mathrm{C}, \mathrm{F}}=1.1 \mathrm{~Hz}\right), 126.3\left(\mathrm{~d}, J_{\mathrm{C}, \mathrm{F}}=2.4 \mathrm{~Hz}\right), 125.2(\mathrm{~d}$, $\left.J_{\mathrm{C}, \mathrm{F}}=15.6 \mathrm{~Hz}\right), 121.5\left(\mathrm{~d}, J_{\mathrm{C}, \mathrm{F}}=6.2 \mathrm{~Hz}\right), 118.23\left(\mathrm{q},{ }^{1} J_{\mathrm{C}, \mathrm{F}}=292.8 \mathrm{~Hz}\right.$, TFA), $109.76\left(\mathrm{~d}, J_{\mathrm{C}, \mathrm{F}}=20.2 \mathrm{~Hz}\right), 61.0,41.7,41.3,39.9,25.3,25.1$. HRMS-ESI: $\mathrm{C}_{34} \mathrm{H}_{37} \mathrm{~F}_{2} \mathrm{~N}_{4} \mathrm{O}_{3}^{+}[\mathrm{M}+\mathrm{H}]^{+}$calcd, 587.2828; found, 587.2828 .

1,3-Bis(4-aminobutyl)-5,5-bis(4-bromo-3-chlorobenzyl)pyrimidine-2,4,6(1H,3H,5H)-trione (6d). To a stirred solution of $\mathbf{5 d}$ $(588 \mathrm{mg}, 0.81 \mathrm{mmol})$ and $\mathrm{Et}_{3} \mathrm{~N}(0.23 \mathrm{~mL}, 1.69 \mathrm{mmol})$ in $i-\mathrm{PrOH} /$ THF (1:1, $10 \mathrm{~mL})$ was added 1,3-propanedithiol $(0.164 \mathrm{~mL}, 1.76$ $\mathrm{mmol})$. After a $48 \mathrm{~h}$ reaction time, $\mathrm{Boc}_{2} \mathrm{O}(528 \mathrm{mg}, 2.42 \mathrm{mmol})$ was added, and the reaction mixture was stirred for $18 \mathrm{~h}$ and evaporated. To the crude mixture was added EtOAc $(20 \mathrm{~mL})$ and water $(15 \mathrm{~mL})$ 
and stirred for $30 \mathrm{~min}$. The organic phase was washed with water $(3 \times$ $15 \mathrm{~mL}$ ) and brine $(15 \mathrm{~mL})$ and concentrated. The resulting crude was purified by automated flash chromatography (EtOAc/heptane) and evaporated. The Boc-protected intermediate was deprotected with TFA $(2 \mathrm{~mL}, 26 \mathrm{mmol})$ in $\mathrm{CH}_{2} \mathrm{Cl}_{2}(5 \mathrm{~mL})$ for $18 \mathrm{~h}$. The reaction mixture was concentrated, and the crude product was purified by $\mathrm{RP}$ automated flash chromatography and lyophilized to afford 6d $(0.542$ $\mathrm{mg}, 77 \%)$ as the TFA salt. ${ }^{1} \mathrm{H}$ NMR $\left(400 \mathrm{MHz}, \mathrm{CD}_{3} \mathrm{OD}\right): \delta 7.59$ (d, $J$ $=8.2 \mathrm{~Hz}, 2 \mathrm{H}), 7.24(\mathrm{~d}, J=2.1 \mathrm{~Hz}, 2 \mathrm{H}), 6.92(\mathrm{dd}, J=8.3,2.1 \mathrm{~Hz}$, 2H), 3.73-3.59 (m, 4H), $3.43(\mathrm{~s}, 4 \mathrm{H}), 3.01-2.76(\mathrm{~m}, 4 \mathrm{H}), 1.59-$ $1.43(\mathrm{~m}, 4 \mathrm{H}), 1.36(\mathrm{tt}, J=9.3,6.0 \mathrm{~Hz}, 4 \mathrm{H}) .{ }^{13} \mathrm{C}$ NMR $(101 \mathrm{MHz}$, $\left.\mathrm{CD}_{3} \mathrm{OD}\right): \delta 171.4,150.7,137.7,135.5,135.3,132.7,130.7,122.6$, 61.0, 44.9, 42.1, 40.2, 26.0, 25.8. HRMS: $\mathrm{C}_{26} \mathrm{H}_{31}{ }^{79} \mathrm{Br}_{2} \mathrm{Cl}_{2} \mathrm{~N}_{4} \mathrm{O}_{3}{ }^{+}[\mathrm{M}+$ $\mathrm{H}]^{+}$calcd, 675.0134; found, 675.0145.

1,3-Bis(4-aminobutyl)-5,5-bis(3,5-dibromobenzyl)pyrimidin2,4,6(1H,3H,5H)-trione (6e). To a stirred solution of $5 \mathbf{e}(810 \mathrm{mg}, 0.99$ $\mathrm{mmol})$ and $\mathrm{Et}_{3} \mathrm{~N}(0.32 \mathrm{~mL}, 2.29 \mathrm{mmol})$ in $i-\mathrm{PrOH} / \mathrm{THF}(1: 1,5 \mathrm{~mL})$ was added 1,3-propanedithiol $(0.20 \mathrm{~mL}, 1.99 \mathrm{mmol})$. The mixture was stirred for $5 \mathrm{~min}$ before addition of $\mathrm{NaBH}_{4}(90 \mathrm{mg}, 2.37 \mathrm{mmol})$. After a $48 \mathrm{~h}$ reaction time, $\mathrm{Boc}_{2} \mathrm{O}(650 \mathrm{mg}, 2.97 \mathrm{mmol})$ was added, and the reaction mixture was stirred for $18 \mathrm{~h}$ and evaporated. To the crude mixture were added EtOAc $(15 \mathrm{~mL})$ and water $(15 \mathrm{~mL})$ and stirred for $30 \mathrm{~min}$. The organic phase was washed with water $(3 \times 15$ $\mathrm{mL})$ and brine $(15 \mathrm{~mL})$ and concentrated. The resulting crude was purified by automated flash chromatography and evaporated. The Boc-protected intermediate was deprotected with TFA $(2 \mathrm{~mL}, 26$ mmol) in $\mathrm{CH}_{2} \mathrm{Cl}_{2}(5 \mathrm{~mL})$ for $18 \mathrm{~h}$. The reaction mixture was concentrated, and the crude product was purified by RP automated flash chromatography and lyophilized to afford 6 e $(374 \mathrm{mg}, 38 \%)$ as the TFA salt. ${ }^{1} \mathrm{H}$ NMR (400 MHz, $\left.\mathrm{CD}_{3} \mathrm{OD}\right): \delta 7.66(\mathrm{~s}, 2 \mathrm{H}), 7.23(\mathrm{~s}$, $4 \mathrm{H}), 3.68(\mathrm{t}, \mathrm{J}=7.7 \mathrm{~Hz}, 4 \mathrm{H}), 3.43(\mathrm{~s}, 4 \mathrm{H}), 3.08-2.82(\mathrm{~m}, 4 \mathrm{H})$, $1.76-1.48(\mathrm{~m}, 4 \mathrm{H}), 1.49-1.32(\mathrm{~m}, 4 \mathrm{H}) .{ }^{13} \mathrm{C}$ NMR $(101 \mathrm{MHz}$ $\left.\mathrm{CD}_{3} \mathrm{OD}\right): \delta 171.2,163.01$ (q, $J=34.4 \mathrm{~Hz}$, TFA), $150.4,140.5,134.5$, 132.7, 124.1, 118.2 (q, $J=293.3 \mathrm{~Hz}, \mathrm{TFA}), 61.2,44.8,42.2,40.3$, 26.3, 25.8. HRMS-ESI: $\mathrm{C}_{26} \mathrm{H}_{31}{ }^{7} \mathrm{Br}_{4} \mathrm{~N}_{4} \mathrm{O}_{3}^{+}[\mathrm{M}+\mathrm{H}]^{+}$calcd, 762.9124; found, 762.9124 .

1,3-Bis(4-aminobutyl)-5,5-bis(3,5-bis(trifluoromethyl)benzyl)pyrimidin-2,4,6(1H,3H,5H)-trione (6f). To a stirred solution of $\mathbf{5 f}(63$ $\mathrm{mg}, 0.81 \mathrm{mmol})$ and $\mathrm{Et}_{3} \mathrm{~N}(0.034 \mathrm{~mL}, 0.24 \mathrm{mmol})$ in $i-\mathrm{PrOH} / \mathrm{THF}$ $(1: 1,2 \mathrm{~mL})$ was added 1,3-propanedithiol $(0.10 \mathrm{~mL}, 0.99 \mathrm{mmol})$. The mixture was stirred for $5 \mathrm{~min}$ before addition of $\mathrm{NaBH}_{4}(92 \mathrm{mg}$, $0.24 \mathrm{mmol})$. After a $48 \mathrm{~h}$ reaction time, $\mathrm{Boc}_{2} \mathrm{O}(70 \mathrm{mg}, 0.32 \mathrm{mmol})$ and $\mathrm{K}_{2} \mathrm{CO}_{3}$ (45 mg, $0.33 \mathrm{mmol}$ ) were added, and the reaction was stirred for another night, before being diluted with EtOAc $(10 \mathrm{~mL})$ and water $(10 \mathrm{~mL})$ and stirred for $1 \mathrm{~h}$. The organic phase was washed with water $(3 \times 15 \mathrm{~mL})$ and brine $(15 \mathrm{~mL})$ and concentrated. The resulting crude was purified by automated flash chromatography and evaporated. The Boc-protected intermediate was deprotected with TFA $(2 \mathrm{~mL}, 26 \mathrm{mmol})$ in $\mathrm{CH}_{2} \mathrm{Cl}_{2}(5 \mathrm{~mL})$ for $18 \mathrm{~h}$. The reaction mixture was concentrated, and the crude product was purified by RP automated flash chromatography and lyophilized to afford $6 f(12 \mathrm{mg}$, $16 \%)$ as the TFA salt. ${ }^{1} \mathrm{H}$ NMR (400 MHz, $\left.\mathrm{CD}_{3} \mathrm{OD}\right): \delta 7.93(\mathrm{~s}, 2 \mathrm{H})$, $7.68(\mathrm{~s}, 4 \mathrm{H}), 3.71(\mathrm{~s}, 4 \mathrm{H}), 3.61-3.54(\mathrm{~m}, 4 \mathrm{H}), 2.87-2.80(\mathrm{~m}, 4 \mathrm{H})$, 1.57-1.46 (m, 4H), 1.33-1.22 (m, 4H). ${ }^{13} \mathrm{C}$ NMR (101 MHz, $\left.\mathrm{CD}_{3} \mathrm{OD}\right): \delta 170.9,150.1,139.4,133.0\left(\mathrm{q},{ }^{2} J_{\mathrm{C}, \mathrm{F}}=33.4 \mathrm{~Hz}\right), 131.6-$ $131.1(\mathrm{~m}), 124.6\left(\mathrm{q},{ }^{1} J_{\mathrm{C}, \mathrm{F}}=272.1 \mathrm{~Hz}\right), 123.0,61.1,44.8,42.3,40.0$, 25.9, 25.7. HRMS-ESI: $\mathrm{C}_{30} \mathrm{H}_{31} \mathrm{~F}_{12} \mathrm{~N}_{4} \mathrm{O}_{3}{ }^{+}[\mathrm{M}+\mathrm{H}]^{+}$calcd, 723.2197; found, 723.2161 .

1,3-Bis(4-aminobutyl)-5,5-bis(4-tert-butylbenzyl)pyrimidin-2,4,6$(1 \mathrm{H}, 3 \mathrm{H}, 5 \mathrm{H})$-trione $(6 \mathrm{~g})$. To a stirred solution of $5 \mathrm{~g}(2.16 \mathrm{~g}$, 3.52 $\mathrm{mmol})$ and $\mathrm{Et}_{3} \mathrm{~N}(0.98 \mathrm{~mL}, 7.05 \mathrm{mmol})$ in $i-\mathrm{PrOH} / \mathrm{THF}(1: 1,10$ $\mathrm{mL})$ was added 1,3-propanedithiol $(0.1 \mathrm{~mL}, 0.99 \mathrm{mmol})$. The mixture was stirred for $5 \mathrm{~min}$ before addition of $\mathrm{NaBH}_{4}(270 \mathrm{mg}, 7.14 \mathrm{mmol})$. After a $72 \mathrm{~h}$ reaction time, $\mathrm{Boc}_{2} \mathrm{O}(1.69 \mathrm{~g}, 7.74 \mathrm{mmol})$ and $\mathrm{K}_{2} \mathrm{CO}_{3}$ $(1.94 \mathrm{~g}, 14.0 \mathrm{mmol})$ were added, and the reaction was stirred for $18 \mathrm{~h}$ and evaporated before adding EtOAc $(20 \mathrm{~mL})$ and water $(15 \mathrm{~mL})$ and stirring for $30 \mathrm{~min}$. The organic phase was washed with water (3 $\times 15 \mathrm{~mL})$ and brine $(15 \mathrm{~mL})$ and concentrated. The resulting crude was purified by automated flash chromatography and evaporated. The Boc-protected intermediate was deprotected with TFA $(2.2 \mathrm{~mL}, 28.7$ mmol) in $\mathrm{CH}_{2} \mathrm{Cl}_{2}(10 \mathrm{~mL})$ for $18 \mathrm{~h}$. The reaction mixture was concentrated, and the crude product was purified by RP automated flash chromatography and lyophilized to afford $\mathbf{6 g}(367 \mathrm{mg}, 85 \%)$ as the TFA salt. ${ }^{1} \mathrm{H}$ NMR $\left(400 \mathrm{MHz}, \mathrm{CD}_{3} \mathrm{OD}\right): \delta 7.25(\mathrm{~d}, J=7.1 \mathrm{~Hz}$, $4 \mathrm{H}), 6.98(\mathrm{~d}, J=7.2 \mathrm{~Hz}, 4 \mathrm{H}), 3.62-3.53(\mathrm{~m}, 4 \mathrm{H}), 3.39(\mathrm{~s}, 4 \mathrm{H}), 2.87$ $(\mathrm{t}, J=7.4 \mathrm{~Hz}, 4 \mathrm{H}), 1.55-1.36(\mathrm{~m}, 4 \mathrm{H}), 1.36-1.15(\mathrm{~m}, 22 \mathrm{H}) .{ }^{13} \mathrm{C}$ NMR (101 MHz, CD $\mathrm{OD}): \delta 172.3,163.0(\mathrm{q}, J=34.4 \mathrm{~Hz}$, TFA), $151.9,151.0,133.5,130.3,126.5,118.2(\mathrm{q}, J=292.8 \mathrm{~Hz}$, TFA), 61.9, $45.9,41.7,40.0,35.3,31.7,25.6,25.5$. HRMS-ESI: $\mathrm{C}_{34} \mathrm{H}_{51} \mathrm{~N}_{4} \mathrm{O}_{3}{ }^{+}[\mathrm{M}$ $+\mathrm{H}]^{+}$calcd, 563.3956; found, 563.3934 .

1,3-Bis(4-aminobutyl)-5,5-bis(3,5-di-tert-butylbenzyl)pyrimidin$2,4,6(1 \mathrm{H}, 3 \mathrm{H}, 5 \mathrm{H})$-trione $(6 \mathrm{~h})$. To a stirred solution of $\mathbf{5 h}(405 \mathrm{mg}$, $0.55 \mathrm{~mol})$ and $\mathrm{Et}_{3} \mathrm{~N}(0.16 \mathrm{~mL}, 1.15 \mathrm{mmol})$ in $i-\mathrm{PrOH} / \mathrm{THF}(1: 1,6$ $\mathrm{mL}$ ) was added 1,3-propanedithiol $(0.12 \mathrm{~mL}, 1.15 \mathrm{mmol})$. The mixture was stirred for $5 \mathrm{~min}$ before addition of $\mathrm{NaBH}_{4}(44 \mathrm{mg}, 1.16$ $\mathrm{mmol})$. After a $72 \mathrm{~h}$ reaction time, $\mathrm{Boc}_{2} \mathrm{O}(490 \mathrm{mg}, 2.25 \mathrm{mmol})$ was added, and the reaction was stirred for another night before being diluted with EtOAc $(10 \mathrm{~mL})$ and water $(10 \mathrm{~mL})$ and stirred for $1 \mathrm{~h}$. The organic phase was washed with water $(3 \times 15 \mathrm{~mL})$ and brine $(15$ $\mathrm{mL}$ ) and concentrated. The resulting crude was purified by automated flash chromatography and evaporated. The Boc-protected intermediate was deprotected with TFA $(1.7 \mathrm{~mL}, 22.2 \mathrm{mmol})$ in $\mathrm{CH}_{2} \mathrm{Cl}_{2}$ (5 $\mathrm{mL}$ ) for $6 \mathrm{~h}$. The reaction mixture was concentrated, and the crude product was purified by RP automated flash chromatography and lyophilized to afford $\mathbf{6 h}(154 \mathrm{mg}, 31 \%)$ as the TFA salt. ${ }^{1} \mathrm{H}$ NMR $\left(400 \mathrm{MHz}, \mathrm{CD}_{3} \mathrm{OD}\right): \delta 7.31(\mathrm{t}, J=1.5 \mathrm{~Hz}, 2 \mathrm{H}), 6.89(\mathrm{~d}, J=1.6 \mathrm{~Hz}$, $4 \mathrm{H}), 3.59\left(\mathrm{t}^{*}, 4 \mathrm{H}\right), 3.44(\mathrm{~s}, 4 \mathrm{H}), 2.78\left(\mathrm{t}^{*}, 4 \mathrm{H}\right), 1.40(\mathrm{p}, J=7.7 \mathrm{~Hz}$, $4 \mathrm{H}), 1.26(\mathrm{~s}, 36 \mathrm{H}), 1.17(\mathrm{p}, J=7.6 \mathrm{~Hz}, 4 \mathrm{H}) .{ }^{13} \mathrm{C} \mathrm{NMR}(101 \mathrm{MHz}$, $\left.\mathrm{CD}_{3} \mathrm{OD}\right): \delta 172.3,162.8$ (q, $\left.J=34.7 \mathrm{~Hz}, \mathrm{TFA}\right), 152.3,151.1,135.8$, $124.7,122.6,118.1(\mathrm{q}, J=292.5 \mathrm{~Hz}, \mathrm{TFA}), 61.8,47.3,42.0,39.9$, 35.6, 31.9, 25.9, 25.5. *Distorted triplets. HRMS-ESI: $\mathrm{C}_{42} \mathrm{H}_{67} \mathrm{~N}_{4} \mathrm{O}_{3}{ }^{+}$ $[\mathrm{M}+\mathrm{H}]^{+}$calcd, 675.5211; found, 675.5211.

Guanylation of Amines (6) to Guanidines (7). 1, 1'-((2,4,6-Trioxo5,5-bis (4-(trifluoromethyl)benzyl)dihydropyrimidine-1,3(2H,4H)diyl)bis(butane-4,1-diyl))diguanidine (7a). To a stirred solution of the TFA salt of $6 \mathrm{a}(33 \mathrm{mg}, 0.41 \mu \mathrm{mol})$ in THF $(3 \mathrm{~mL})$ were added $\mathrm{NaHCO}_{3}(27 \mathrm{mg}, 0.31 \mathrm{mmol})$ and $N, N^{\prime}$-bis-Boc-1-guanylpyrazole $(27 \mathrm{mg}, 0.86 \mathrm{mmol})$. The reaction was stirred at room temperature for $48 \mathrm{~h}$ until TLC $\left(\mathrm{CH}_{3} \mathrm{Cl}\right)$ showed full guanylation of the diamine. The reaction mixture was concentrated, and the crude product was then dissolved in EtOAc $(10 \mathrm{~mL})$ and washed with $10 \%$ citric acid soln $(2 \times 10 \mathrm{~mL}), 10 \% \mathrm{NaHCO}_{3}$ soln $(10 \mathrm{~mL})$, and brine $(10 \mathrm{~mL})$. The organic phase was dried over $\mathrm{Na}_{2} \mathrm{SO}_{4}$, filtered, and concentrated. The crude product was purified by automated flash chromatography, and the resulting Boc-protected intermediate was deprotected with TFA $(0.2 \mathrm{~mL}, 2.61 \mathrm{mmol})$ in $\mathrm{CH}_{2} \mathrm{Cl}_{2}(2 \mathrm{~mL})$ for $18 \mathrm{~h}$. The reaction mixture was concentrated, and the crude was purified by $\mathrm{RP}$ automated flash chromatography and lyophilized to afford 7a (24 $\mathrm{mg}, 65 \%)$ as a white powder. ${ }^{1} \mathrm{H}$ NMR $\left(400 \mathrm{MHz}, \mathrm{CD}_{3} \mathrm{OD}\right): \delta 7.56$ $(\mathrm{d}, J=8.1 \mathrm{~Hz}, 4 \mathrm{H}), 7.28(\mathrm{~d}, J=8.0 \mathrm{~Hz}, 4 \mathrm{H}), 3.62(\mathrm{t}, J=6.7 \mathrm{~Hz}, 4 \mathrm{H})$, $3.57(\mathrm{~s}, 4 \mathrm{H}), 3.11(\mathrm{t}, J=6.5 \mathrm{~Hz}, 4 \mathrm{H}), 1.37-1.28(\mathrm{~m}, 8 \mathrm{H}){ }^{13} \mathrm{C} \mathrm{NMR}$ $\left(101 \mathrm{MHz}, \mathrm{CD}_{3} \mathrm{OD}\right): \delta 171.5,162.4\left(\mathrm{q},{ }^{2} J_{\mathrm{C}, \mathrm{F}}=35.5 \mathrm{~Hz}, \mathrm{TFA}\right), 158.7$, $150.8,140.9,131.5,131.1\left(\mathrm{q},{ }^{2} J_{\mathrm{C}, \mathrm{F}}=32.4 \mathrm{~Hz}\right), 126.7-126.4(\mathrm{~m})$, $125.46\left(\mathrm{q},{ }^{1} J_{\mathrm{C}, \mathrm{F}}=271.3 \mathrm{~Hz}\right), 117.9\left(\mathrm{q},{ }^{1} J_{\mathrm{C}, \mathrm{F}}=291.1 \mathrm{~Hz}, \mathrm{TFA}\right), 61.1$, 45.9, 42.3, 41.8, 26.9, 25.8. HRMS-ESI: $\mathrm{C}_{30} \mathrm{H}_{37} \mathrm{~F}_{6} \mathrm{~N}_{8} \mathrm{O}_{3}{ }^{+}[\mathrm{M}+\mathrm{H}]^{+}$ calcd, 671.2887; found, 671.2836.

1,1'-((5,5-Bis(naphthalen-2-ylmethyl)-2,4,6-trioxodihydropyrimidine-1,3(2H,4H)-diyl)bis(butane-4,1-diyl))diguanidine (7b). To a stirred solution of the TFA salt of $\mathbf{6 b}(54 \mathrm{mg}, 0.069 \mathrm{mmol})$ in THF ( $4 \mathrm{~mL}$ ) were added $N, N^{\prime}$-bis-Boc-1-guanylpyrazole $(63 \mathrm{mg}, 0.20$ $\mathrm{mmol})$ and $\mathrm{NaHCO}_{3}(41 \mathrm{mg}, 0.48 \mathrm{mmol})$ and stirred at room temperature for $48 \mathrm{~h}$ until TLC $\left(\mathrm{CHCl}_{3}\right)$ showed full conversion. The reaction mixture was diluted with EtOAc $(5 \mathrm{~mL})$, washed with $10 \%$ citric acid soln $(2 \times 10 \mathrm{~mL})$ and brine $(10 \mathrm{~mL})$, dried over $\mathrm{Na}_{2} \mathrm{SO}_{4}$, filtered, and concentrated. The Boc-protected intermediate was dissolved in $\mathrm{CHCl}_{3}$ and adsorbed onto Celite before purification on a silica column using $\mathrm{CHCl}_{3}$ as the mobile phase. The Boc-protected intermediate $(64 \mathrm{mg}$ of a total of $104 \mathrm{mg}, 0.057 \mathrm{mmol}$ ) was deprotected with TFA $(0.2 \mathrm{~mL})$ in $\mathrm{CH}_{2} \mathrm{Cl}_{2}(4 \mathrm{~mL})$ overnight. The reaction mixture was concentrated and purified by $\mathrm{RP}$ automated flash 
chromatography and lyophilized to afford $7 \mathbf{b}(60 \mathrm{mg}, 99 \%)$ as a white powder. ${ }^{1} \mathrm{H}$ NMR $\left(400 \mathrm{MHz}, \mathrm{CD}_{3} \mathrm{OD}\right): \delta 7.85-7.69(\mathrm{~m}, 6 \mathrm{H}), 7.59$ (s, 2H), 7.53-7.40 (m, 4H), $7.20(\mathrm{dd}, J=8.4,1.8 \mathrm{~Hz}, 2 \mathrm{H}), 3.69(\mathrm{~s}$, $4 \mathrm{H}), 3.54(\mathrm{t}, J=7.1 \mathrm{~Hz}, 4 \mathrm{H}), 2.80(\mathrm{t}, J=7.1 \mathrm{~Hz}, 4 \mathrm{H}), 1.21-1.08(\mathrm{~m}$, $4 \mathrm{H}), 1.08-0.98(\mathrm{~m}, 4 \mathrm{H}) .{ }^{13} \mathrm{C} \mathrm{NMR}\left(101 \mathrm{MHz}, \mathrm{CD}_{3} \mathrm{OD}\right): \delta 172.3$, $163.1(\mathrm{q}, J=34.3 \mathrm{~Hz}, \mathrm{TFA}), 158.5,151.0,134.7,134.1,134.0,129.8$, 129.4, 128.7, 128.6, 128.3, 127.6, 127.3, 118.2 (q, $J=293.0 \mathrm{~Hz}, \mathrm{TFA})$, 62.0, 46.6, 42.1, 41.8, 26.6, 25.9. HRMS-ESI: $\mathrm{C}_{36} \mathrm{H}_{43} \mathrm{~N}_{8} \mathrm{O}_{3}{ }^{+}[\mathrm{M}+\mathrm{H}]^{+}$ calcd, 635.3450; found, 635.3448.

1,1'-((5,5-Bis((4-fluoronaphthalen-1-yl)methyl)-2,4,6-trioxodihydropyrimidine-1,3(2H,4H)-diyl)bis (butane-4, 1-diyl))diguanidine (7c). To a stirred solution of the TFA salt of $6 \mathrm{c}(35 \mathrm{mg}, 43 \mu \mathrm{mol})$ in THF ( $3 \mathrm{~mL}$ ) were added $N, N^{\prime}$-bis-Boc-1-guanylpyrazole $(38 \mathrm{mg}, 122$ $\mu \mathrm{mol})$ and $\mathrm{NaHCO}_{3}(25 \mathrm{mg}, 0.29 \mathrm{mmol})$ and stirred at room temperature for $48 \mathrm{~h}$ until TLC $\left(\mathrm{CHCl}_{3}\right)$ showed full conversion. The reaction mixture was diluted with EtOAc $(5 \mathrm{~mL})$, washed with $10 \%$ citric acid soln and brine, dried over $\mathrm{Na}_{2} \mathrm{SO}_{4}$, filtered, and concentrated. The Boc-protected intermediate was dissolved in $\mathrm{CHCl}_{3}$ and adsorbed onto Celite before purification on a silica column using $\mathrm{CHCl}_{3}$ as the mobile phase. The Boc-protected intermediate $(41 \mathrm{mg}$ of a total of $95 \mathrm{mg}, 0.038 \mathrm{mmol}$ ) was deprotected with TFA $(0.1 \mathrm{~mL})$ in $\mathrm{CH}_{2} \mathrm{Cl}_{2}(4 \mathrm{~mL})$ overnight. The reaction mixture was concentrated and purified by RP automated flash chromatography and lyophilized to afford $7 \mathrm{c}(20 \mathrm{mg}, 52 \%)$ as a white powder. ${ }^{1} \mathrm{H}$ NMR $\left(400 \mathrm{MHz}, \mathrm{CD}_{3} \mathrm{OD}\right): \delta 8.32(\mathrm{~d}, J=8.6 \mathrm{~Hz}, 2 \mathrm{H})$, $8.06(\mathrm{~d}, J=7.9 \mathrm{~Hz}, 2 \mathrm{H}), 7.71-7.55(\mathrm{~m}, 4 \mathrm{H}), 7.25(\mathrm{dd}, J=8.0,5.5$ $\mathrm{Hz}, 2 \mathrm{H}), 7.06(\mathrm{dd}, J=10.2,8.1 \mathrm{~Hz}, 2 \mathrm{H}), 4.12(\mathrm{~s}, 4 \mathrm{H}), 3.35(\mathrm{t}, J=7.2$ $\mathrm{Hz}, 4 \mathrm{H}), 2.87(\mathrm{t}, J=7.1 \mathrm{~Hz}, 4 \mathrm{H}), 1.00(\mathrm{p}, J=7.2 \mathrm{~Hz}, 4 \mathrm{H}), 0.86(\mathrm{p}, J$ $=7.4,6.8 \mathrm{~Hz}, 4 \mathrm{H}) \cdot{ }^{13} \mathrm{C} \mathrm{NMR}\left(101 \mathrm{MHz}, \mathrm{CD}_{3} \mathrm{OD}\right): \delta 172.2,163.1(\mathrm{q}$, $\left.{ }^{2} J_{\mathrm{C}, \mathrm{F}}=34.1 \mathrm{~Hz}, \mathrm{TFA}\right), 159.6\left(\mathrm{~d},{ }^{1} J_{\mathrm{C}, \mathrm{F}}=251.6 \mathrm{~Hz}\right), 158.5,150.9,134.5$ $\left(\mathrm{d},{ }^{3} J_{\mathrm{C}, \mathrm{F}}=4.3 \mathrm{~Hz}\right), 129.2\left(\mathrm{~d}, J_{\mathrm{C}, \mathrm{F}}=4.6 \mathrm{~Hz}\right), 128.9\left(\mathrm{~d}, J_{\mathrm{C}, \mathrm{F}}=8.5 \mathrm{~Hz}\right)$, $128.2,127.6\left(\mathrm{~d}, J_{\mathrm{C}, \mathrm{F}}=1.6 \mathrm{~Hz}\right), 126.2\left(\mathrm{~d}, J_{\mathrm{C}, \mathrm{F}}=2.5 \mathrm{~Hz}\right), 125.2\left(\mathrm{~d}, J_{\mathrm{C}, \mathrm{F}}\right.$ $=15.8 \mathrm{~Hz}), 121.5\left(\mathrm{~d}, J_{\mathrm{C}, \mathrm{F}}=6.2 \mathrm{~Hz}\right), 118.2\left(\mathrm{q}, J_{\mathrm{C}, \mathrm{F}}=292.8 \mathrm{~Hz}, \mathrm{TFA}\right)$, $109.7\left(\mathrm{~d}, J_{\mathrm{C}, \mathrm{F}}=20.2 \mathrm{~Hz}\right), 60.9,42.1,41.8,41.4,26.5$, 25.4. HRMSESI: $\mathrm{C}_{36} \mathrm{H}_{41} \mathrm{~F}_{2} \mathrm{~N}_{8} \mathrm{O}_{3}^{+}[\mathrm{M}+\mathrm{H}]^{+}$calcd, 671.3264; found, 671.3244.

1,1'-((5,5-Bis(4-bromo-3-chlorobenzyl)-2,4,6-trioxodihydropyrimidine-1,3(2H,4H)-diyl)bis(butane-4, 1 -diyl))diguanidine (7d). To a stirred solution of the TFA salt of $6 \mathbf{d}(203 \mathrm{mg}, 0.299 \mathrm{mmol})$ in THF $(20 \mathrm{~mL})$ were added $\mathrm{NaHCO}_{3}(155 \mathrm{mg}, 1.12 \mathrm{mmol})$ and $N, N^{\prime}$-bisBoc-1-guanylpyrazole $(350 \mathrm{mg}, 1.1 \mathrm{mmol})$ and stirred at room temperature for $48 \mathrm{~h}$ until MS analysis showed full guanylation. The reaction mixture was filtered and concentrated. The crude product was dissolved in EtOAc $(15 \mathrm{~mL})$ and washed with brine $(2 \times 15 \mathrm{~mL})$. The organic phase was dried over $\mathrm{Na}_{2} \mathrm{SO}_{4}$, filtered, and concentrated. The crude product was purified by automated flash chromatography, and the resulting Boc-protected intermediate was deprotected with TFA $(2 \mathrm{~mL})$ in $\mathrm{CH}_{2} \mathrm{Cl}_{2}(2 \mathrm{~mL})$ for $18 \mathrm{~h}$. The reaction mixture was concentrated, and the crude was purified by $\mathrm{RP}$ automated flash chromatography and lyophilized to afford $\mathbf{7 d}$ as a white powder. The yield was not determined. ${ }^{1} \mathrm{H}$ NMR $\left(400 \mathrm{MHz}, \mathrm{CD}_{3} \mathrm{OD}\right): \delta 7.57$ (d, $J$ $=8.2 \mathrm{~Hz}, 2 \mathrm{H}), 7.22(\mathrm{~d}, J=2.1 \mathrm{~Hz}, 2 \mathrm{H}), 6.92(\mathrm{dd}, J=8.3,2.1 \mathrm{~Hz}$, $2 \mathrm{H}), 3.74-3.61(\mathrm{~m}, 4 \mathrm{H}), 3.43(\mathrm{~s}, 4 \mathrm{H}), 3.23-3.12(\mathrm{~m}, 4 \mathrm{H}), 1.47-$ $1.29(\mathrm{~m}, 8 \mathrm{H}) .{ }^{13} \mathrm{C}$ NMR (101 MHz, CD $\left.3 \mathrm{OD}\right): \delta 171.5,158.6,150.7$, 137.7, 135.5, 135.3, 132.6, 130.7, 122.6, 61.0, 45.0, 42.5, 42.0, 26.9, 26.1. HRMS-ESI: $\mathrm{C}_{28} \mathrm{H}_{35}{ }^{79} \mathrm{Br}_{2} \mathrm{Cl}_{2} \mathrm{~N}_{8} \mathrm{O}_{3}{ }^{+}[\mathrm{M}+\mathrm{H}]^{+}$calcd, 759.0570; found, 759.0578 .

1,1'-((5,5-Bis(3,5-dibromobenzyl)-2,4,6-trioxodihydropyrimidine1,3(2H,4H)-diyl)bis(butane-4,1-diyl))diguanidine (7e). To a stirred solution of the TFA salt of $6 \mathrm{e}(360 \mathrm{mg}, 0.362 \mathrm{mmol})$ in THF $(5 \mathrm{~mL})$ were added $\mathrm{NaHCO}_{3}(240 \mathrm{mg}, 2.86 \mathrm{mmol})$ and $N, N^{\prime}$-bis-Boc-1guanylpyrazole $(564 \mathrm{mg}, 1.82 \mathrm{mmol})$ and stirred at room temperature for $48 \mathrm{~h}$ until MS analysis showed full guanylation. The reaction mixture was filtered and concentrated. The crude product was dissolved in EtOAc $(20 \mathrm{~mL})$ and washed with brine $(2 \times 20 \mathrm{~mL})$. The organic phase was dried over $\mathrm{Na}_{2} \mathrm{SO}_{4}$, filtered, and concentrated. The crude product was purified by automated flash chromatography, and the resulting Boc-protected intermediate was deprotected with TFA $(0.2 \mathrm{~mL})$ in $\mathrm{CH}_{2} \mathrm{Cl}_{2}(2 \mathrm{~mL})$ for $18 \mathrm{~h}$. The reaction mixture was concentrated, and the crude was purified by RP automated flash chromatography and lyophilized to afford $7 \mathrm{e}(44 \mathrm{mg}, 11 \%)$ as a white powder. ${ }^{1} \mathrm{H}$ NMR $\left(400 \mathrm{MHz}, \mathrm{CD}_{3} \mathrm{OD}\right): \delta 7.65(\mathrm{t}, J=1.8 \mathrm{~Hz}, 2 \mathrm{H})$, $7.22(\mathrm{~d}, J=1.7 \mathrm{~Hz}, 4 \mathrm{H}), 3.67(\mathrm{t}, J=7.2 \mathrm{~Hz}, 4 \mathrm{H}), 3.42(\mathrm{~s}, 4 \mathrm{H}), 3.20$ $(\mathrm{t}, J=6.7 \mathrm{~Hz}, 4 \mathrm{H}), 1.52-1.36(\mathrm{~m}, 8 \mathrm{H}) .{ }^{13} \mathrm{C}$ NMR $(101 \mathrm{MHz}$, $\left.\mathrm{CD}_{3} \mathrm{OD}\right): \delta 171.3,163.0(\mathrm{q}, J=34.6 \mathrm{~Hz}$, TFA), 158.6, 150.5, 140.5, $134.5,132.6,124.1,118.2(\mathrm{q}, J=292.7 \mathrm{~Hz}, \mathrm{TFA}), 61.2,44.9,42.6$, 42.1, 27.0, 26.4. HRMS-ESI: $\mathrm{C}_{28} \mathrm{H}_{35}{ }^{79} \mathrm{Br}_{2}{ }^{81} \mathrm{Br}_{2} \mathrm{~N}_{8} \mathrm{O}_{3}{ }^{+}[\mathrm{M}+\mathrm{H}]^{+}$calcd, 850.9525; found, 850.9532 .

1,1'-((5,5-Bis(3,5-bis(trifluoromethyl)benzyl)-2,4,6-trioxodihydropyrimidine-1,3(2H,4H)-diyl)bis(butane-4,1-diyl))diguanidine (7f). To a stirred solution of the TFA salt of $6 f(21 \mathrm{mg}, 0.02 \mathrm{mmol})$ in THF $(1 \mathrm{~mL})$ were added DIPEA $(15.4 \mu \mathrm{L}, 0.09 \mathrm{mmol})$ and $N, N^{\prime}$-bisBoc-1-guanylpyrazole $(17 \mathrm{mg}, 0.06 \mathrm{mmol})$. The reaction was stirred at $45{ }^{\circ} \mathrm{C}$ for $2 \mathrm{~h}$. The reaction mixture was concentrated, and the crude product was dissolved in EtOAc $(10 \mathrm{~mL})$ and washed with $10 \%$ citric acid soln $(2 \times 10 \mathrm{~mL}), 10 \% \mathrm{NaHCO}_{3}$ soln $(10 \mathrm{~mL})$, and brine $(10 \mathrm{~mL})$. The organic phase was dried over $\mathrm{MgSO}_{4}$, filtered, and concentrated. The crude product was purified by automated flash chromatography, and the resulting Boc-protected intermediate was deprotected with TFA $(25 \mu \mathrm{L})$ in $\mathrm{CH}_{2} \mathrm{Cl}_{2}$ for $18 \mathrm{~h}$. The reaction mixture was concentrated, and the crude was purified by $\mathrm{RP}$ automated flash chromatography and lyophilized to afford $7 \mathrm{f}(4 \mathrm{mg}$, $17 \%)$ as a white powder. ${ }^{1} \mathrm{H}$ NMR $\left(400 \mathrm{MHz}, \mathrm{CD}_{3} \mathrm{OD}\right): \delta 7.91(\mathrm{~s}$, $2 \mathrm{H}), 7.67(\mathrm{~d}, J=1.7 \mathrm{~Hz}, 4 \mathrm{H}), 3.71(\mathrm{~s}, 4 \mathrm{H}), 3.63-3.53(\mathrm{~m}, 4 \mathrm{H}), 3.10$ $(\mathrm{t}, J=7.1 \mathrm{~Hz}, 4 \mathrm{H}), 1.40(\mathrm{tt}, J=7.7,4.0 \mathrm{~Hz}, 4 \mathrm{H}), 1.36-1.24(\mathrm{~m}, 4 \mathrm{H})$. ${ }^{13} \mathrm{C}$ NMR $\left(101 \mathrm{MHz}, \mathrm{CD}_{3} \mathrm{OD}\right): \delta 171.0,158.7,150.2,139.4,133.1$ $\left(\mathrm{q},{ }^{2} J_{\mathrm{C}, \mathrm{F}}=33.4 \mathrm{~Hz}, 4 \mathrm{C}\right), 131.4-131.2(\mathrm{~m}, 4 \mathrm{C}), 124.54\left(\mathrm{q},{ }^{1} \mathrm{~J}_{\mathrm{C}, \mathrm{F}}=\right.$ $272.1 \mathrm{~Hz}, 4 \mathrm{C}$ ), 123.0-122.8 (m, 2C), 61.1, 44.9, 42.5, 41.7, 26.8, 26.0. HRMS-ESI: $\mathrm{C}_{30} \mathrm{H}_{31} \mathrm{~F}_{12} \mathrm{~N}_{4} \mathrm{O}_{3}{ }^{+}[\mathrm{M}+\mathrm{H}]^{+}$calcd 807.2635; found, 807.2632 .

1,1'-((5,5-Bis(4-tert-butylbenzyl)-2,4,6-trioxodihydropyrimidine$1,3(2 \mathrm{H}, 4 \mathrm{H})$-diyl)bis(butane-4,1-diyl))diguanidine (7g). To a stirred solution of the TFA salt of $6 \mathrm{~g}(129 \mathrm{mg}, 0.16 \mathrm{mmol})$ in THF $(2 \mathrm{~mL})$ were added $\mathrm{NaHCO}_{3}(68 \mathrm{mg}, 0.81 \mathrm{mmol})$ and $N, N^{\prime}$-bis-Boc-1guanylpyrazole $(200 \mathrm{mg}, 0.64 \mathrm{mmol})$. The reaction was stirred at room temperature for $48 \mathrm{~h}$. The reaction mixture was concentrated, and the crude product was dissolved in EtOAc $(20 \mathrm{~mL})$ and washed with $10 \%$ citric acid soln $(2 \times 20 \mathrm{~mL}), 10 \% \mathrm{NaHCO}_{3}$ soln $(20 \mathrm{~mL})$, and brine $(20 \mathrm{~mL})$. The organic phase was dried over $\mathrm{Na}_{2} \mathrm{SO}_{4}$, filtered, and concentrated. The crude product was purified by automated flash chromatography, and the resulting Boc-protected intermediate was deprotected with TFA $(1 \mathrm{~mL})$ in $\mathrm{CH}_{2} \mathrm{Cl}_{2}$ for $18 \mathrm{~h}$. The reaction mixture was concentrated, and the crude was purified by $\mathrm{RP}$ automated flash chromatography and lyophilized to afford $7 \mathrm{~g}$ (16 $\mathrm{mg}, 11 \%)$ as a white powder. ${ }^{1} \mathrm{H}$ NMR $\left(400 \mathrm{MHz}, \mathrm{CD}_{3} \mathrm{OD}\right): \delta 7.24$ $(\mathrm{d}, J=8.3 \mathrm{~Hz}, 4 \mathrm{H}), 6.98(\mathrm{~d}, J=8.3 \mathrm{~Hz}, 4 \mathrm{H}), 3.58(\mathrm{t}, J=6.7 \mathrm{~Hz}, 4 \mathrm{H})$, $3.39(\mathrm{~s}, 4 \mathrm{H}), 3.13(\mathrm{t}, J=6.6 \mathrm{~Hz}, 4 \mathrm{H}), 1.39-1.29(\mathrm{~m}, 8 \mathrm{H}), 1.24(\mathrm{~s}$, $18 \mathrm{H}) .{ }^{13} \mathrm{C}$ NMR (101 MHz, CD $\left.\mathrm{OD}\right): \delta 172.4,162.4(\mathrm{q}, J=35.6 \mathrm{~Hz}$, TFA), 158.7, 151.9, 151.2, 133.4, 130.3, 126.4, 117.9 (q, $J=291.5 \mathrm{~Hz}$, TFA), 61.9, 45.9, 42.0, 41.9, 35.3, 31.7, 26.8, 25.8. HRMS-ESI: $\mathrm{C}_{36} \mathrm{H}_{55} \mathrm{~N}_{8} \mathrm{O}_{3}^{+}[\mathrm{M}+\mathrm{H}]^{+}$calcd, 647.4393; found, 647.4378.

1,1'-((5,5-Bis(3,5-di-tert-butylbenzyl)-2,4,6-trioxodihydropyrimidine-1,3(2H,4H)-diyl)bis(butane-4,1-diyl))diguanidine ( $7 \mathrm{~h})$. To a stirred solution of the TFA salt of $6 \mathbf{h}(118 \mathrm{mg}, 0.13 \mathrm{mmol})$ in THF $(3 \mathrm{~mL})$ were added $N, N^{\prime}$-bis-Boc-1-guanylpyrazole $(245 \mathrm{mg}$, $0.79 \mathrm{mmol})$ and $\mathrm{NaHCO}_{3}(49 \mathrm{mg}, 0.59 \mathrm{mmol})$ and stirred at room temperature for $48 \mathrm{~h}$ until TLC $\left(\mathrm{CHCl}_{3}\right)$ showed full conversion. The reaction mixture was diluted with EtOAc $(5 \mathrm{~mL})$, washed with $10 \%$ citric acid soln and brine, dried over $\mathrm{Na}_{2} \mathrm{SO}_{4}$, filtered, and concentrated. The crude was purified by automated flash chromatography, and the resulting Boc-protected intermediate was deprotected with TFA $(1.5 \mathrm{~mL})$ in $\mathrm{CH}_{2} \mathrm{Cl}_{2}(1.5 \mathrm{~mL})$ for $4 \mathrm{~h}$. The reaction mixture was concentrated, and the crude was purified by RP automated flash chromatography and lyophilized to afford $7 \mathbf{h}(44 \mathrm{mg}, 34 \%)$ as a white powder. ${ }^{1} \mathrm{H}$ NMR $\left(400 \mathrm{MHz}, \mathrm{CD}_{3} \mathrm{OD}\right): \delta 7.30(\mathrm{t}, J=1.8 \mathrm{~Hz}, 2 \mathrm{H})$, $6.89(\mathrm{~d}, J=1.8 \mathrm{~Hz}, 4 \mathrm{H}), 3.58^{*}(\mathrm{t}, J=7.5 \mathrm{~Hz}, 4 \mathrm{H}), 3.44(\mathrm{~s}, 4 \mathrm{H}), 3.06$ $(\mathrm{t}, J=7.0 \mathrm{~Hz}, 4 \mathrm{H}), 1.38-1.14(\mathrm{~m}, 44 \mathrm{H}) .{ }^{13} \mathrm{C}$ NMR $(101 \mathrm{MHz}$, $\left.\mathrm{CD}_{3} \mathrm{OD}\right): \delta 172.4,162.8(\mathrm{q}, J=35.2 \mathrm{~Hz}$, TFA), 158.6, 152.3, 151.3, $135.8,124.6,122.6,118.0$ (q, $J=292.3 \mathrm{~Hz}$, TFA), 61.7, 47.3, 42.4, 41.8 , 35.6, 31.9, 26.7, 26.2. *Distorted triplet. HRMS-ESI: $\mathrm{C}_{44} \mathrm{H}_{71} \mathrm{~N}_{8} \mathrm{O}_{3}^{+}[\mathrm{M}+\mathrm{H}]^{+}$calcd, 759.5644; found, 759.5637. 
Biological Test Methods. The bacterial reference strains are displayed in Table 1 for the first antimicrobial screening. The Norwegian National Advisory Unit on Detection of Antimicrobial Resistance (K-res), University Hospital of Northern-Norway (UNN), provided the collection of 30 multi-drug-resistant isolates in Table 2. All isolates were deposited at the Norwegian Organization for Surveillance of Resistant Microorganisms (NORM) in the period of 2012-2014.

MIC Assay. The working solutions of the test derivatives were prepared with up to $100 \%$ dimethyl sulfoxide (DMSO) and stored at $-20{ }^{\circ} \mathrm{C}$. If necessary, the solutions were heated to $40-80{ }^{\circ} \mathrm{C}$ before testing to facilitate complete dissolution. Double-distilled water was used in all dilutions prepared. The final concentration of DMSO in the test series was $\leq 1 \%$ and did not affect the assay results. A microdilution susceptibility test was used for MIC determination according to CLSI M07-A9 ${ }^{41}$ with modifications as described by Igumnova et al. ${ }^{42}$ Briefly, the bacterial inoculum was adjusted to approximately $2.5-3 \times 10^{4}$ cells $/ \mathrm{mL}$ in the Mueller-Hinton broth (MHB, Difco Laboratories, USA) and incubated in a ratio of 1:1 with test derivatives in polystyrene 96-well flat-bottomed microplates (NUNC, Roskilde, Denmark). The positive growth control (without test derivatives) and negative control (without bacteria) were included. The reference antibiotic was oxytetracycline hydrochloride (Sigma-Aldrich, Saint Louis, MO, USA). The microplates were incubated in an EnVision microplate reader (PerkinElmer, Turku, Finland) placed in an incubator set to $35^{\circ} \mathrm{C}$ for $48 \mathrm{~h}$. The MIC value was defined as the lowest concentration of the derivative resulting in no bacterial growth as determined by $\mathrm{OD}_{600}$ measurement. All derivatives were tested in three parallels.

Antimicrobial Screening against Clinical Isolates. The MIC assay was performed as explained above with some exceptions; the working solutions of the test derivatives were prepared from the concentrated DMSO stocks stored at room temperature, the density of the bacterial inoculum was increased $40 \times$ to $1-1.2 \times 10^{6}$ cells/ $\mathrm{mL}$, enterococci were incubated in the Brain Heart Infusion broth (BHIB, Difco Laboratories, USA), the polypropylene microplates (Greiner Bio-One, Frickenhausen, Germany) were incubated for $24 \mathrm{~h}$, and the derivatives were tested in four parallels.

Determination of Hemolytic Activity. The protocol was adapted from Paulsen et al. ${ }^{17}$ Hemolysis was determined using a heparinized fraction $(10 \mathrm{IU} / \mathrm{mL})$ of freshly drawn blood. The blood collected in ethylenediaminetetraacetic acid-containing test tubes (Vacutest, KIMA, Arzergrande, Italy) was used for the determination of the hematocrit (hct). The heparinized blood was washed $3 \times$ with pre-warmed phosphate-buffered saline (PBS) and adjusted to a final hct of $4 \%$. Derivatives in DMSO $(50 \mathrm{mM})$ were added to a 96 -well polypropylene V-bottom plate (NUNC, Fisher Scientific, Oslo, Norway) and serially diluted. The test concentration range was $500-4 \mu \mathrm{M}$ with DMSO contents $\leq 1 \%$. A solution of $1 \%$ triton X-100 was used as a positive control for $100 \%$ hemolysis. As a negative control, a solution of $1 \%$ DMSO in PBS was included. No signs of DMSO toxicity were detected. RBCs ( $1 \% \mathrm{v} / \mathrm{v}$ final concentration) were added to the well plate and incubated at $37^{\circ} \mathrm{C}$ and $800 \mathrm{rpm}$ for $1 \mathrm{~h}$. After centrifugation ( $5 \mathrm{~min}, 3000 \mathrm{~g}$ ), $100 \mu \mathrm{L}$ of each well was transferred to a 96-well flat-bottomed microtiter plate, and absorbance was measured at $545 \mathrm{~nm}$ with a microplate reader (VersaMaxTM, Molecular Devices, Sunnyvale, CA, USA). The percentage of hemolysis was calculated as the ratio of the absorbance in the derivative-treated and surfactant-treated samples, corrected for the PBS background. Three independent experiments were performed, and $\mathrm{EC}_{50}$ values are presented as averages.

Determination of Toxicity against MRC5 and HepG2. Adherent, non-malignant lung fibroblasts MRC5 (ATCC CCL171TM) and human hepatocellular carcinoma cells HepG2 (ATCC HB-8065) were used as toxicity control. MRC5 cells, suspended in Eagle's minimal essential medium (MEM) with $10 \%$ fetal bovine serum, $2 \mathrm{mM}$ stable glutamine, $1 \%$ non-essential amino acids, $1 \%$ sodium pyruvate, $2 \% \mathrm{NaHCO}_{3}$, and $10 \mu \mathrm{g} / \mathrm{mL}$ gentamicin, were seeded in 96-well microtiter plates at 15,000 cells/well. HepG2 cells, suspended in Eagle's MEM with $10 \%$ fetal bovine serum, $1 \mathrm{mM}$ stable glutamine, $1 \%$ non-essential amino acids, $1 \%$ sodium pyruvate, and 10 $\mu \mathrm{g} / \mathrm{mL}$ gentamicin, were seeded in 96 -well microtiter plates at 20,000 cells/well (adherent cell lines). The adherent cell lines were incubated for $24 \mathrm{~h}$ before adding compounds $\mathbf{6 a}-\mathbf{h}$ and $7 \mathbf{a}-\mathbf{h}$ and were then incubated for $4 \mathrm{~h}$. The cell viability was determined by a colorimetric 3-(4,5-dimethylthiazol-2-yl)-5-(3-carboxymethoxyphenyl)-2-(4-sulfophenyl)- $2 \mathrm{H}$-tetrazolium assay. At the end of the exposure time, $10 \mu \mathrm{L}$ of Cell Titer 96 Aqueous One Solution Reagent (Promega, Madison, WI, USA) was added to each well, and the plates were incubated for 1 h before absorbance was measured using a DTX 880 multimode detector (Beckman Coulter, CA, USA) at $485 \mathrm{~nm}$. Cells in their respective growth medium were used as negative control, and cells treated with $10 \%$ DMSO were used as positive control. Growth inhibition was determined by using the measured optical density (OD) and was calculated as follows: cell survival $(\%)=(\mathrm{OD}$ treated well - OD positive control well)/(OD negative control well - OD positive control well) $\times 100$.

In Vivo Murine Neutropenic Peritonitis Model. The MIC of 7e (3,5-di-Br) against E. coli (EC106-09) and K. pneumoniae (KP3010) was determined according to the CLSI guidelines. The concentration range used was $0.032-32 \mu \mathrm{g} / \mathrm{mL}$. Colistin was included as a comparator and quality control (QC), and E. coli (ATCC 25922) was included as a QC strain. The MIC of colistin against E. coli (ATCC 25922) was within the CLSI QC range 0.25-2 $\mu \mathrm{g} / \mathrm{mL}$, indicating a correct procedure. Derivative $7 \mathrm{e}(3,5-\mathrm{di}-\mathrm{Br})$ was dissolved in PEG400 to $10 \mathrm{mg} / \mathrm{mL}$ and further diluted in $0.0015 \mathrm{M}$ Tris buffer to concentrations of 1 and $0.2 \mathrm{mg} / \mathrm{mL}$. The in vivo efficacy of compound 7e (3,5-di-Br) against E. coli (EC106-09) and K. pneumoniae (KP3010) in 32 female neutropenic NMRI mice (weight $28-32 \mathrm{~g}$ ) was investigated after i.p. injection of 1.4 and $2.8 \mathrm{mg} / \mathrm{kg}$ given 1 and $3 \mathrm{~h}$ post-infection at Statens Serum Institute (SSI) in Denmark. ${ }^{35}$ Mice were first rendered neutropenic with injections of cyclophosphamide (day-4 and day-1) and on day 0 inoculated with $E$. coli (EC106-09) or K. pneumoniae (KP3010) before being treated with $7 \mathbf{e}(3,5-\mathrm{di}-\mathrm{Br})$ and the control antibiotics colistin $(5 \mathrm{mg} / \mathrm{kg})$, ciprofloxacin $(13 \mathrm{mg} / \mathrm{kg})$, or vehicle $1 \mathrm{~h}$ post-infection. Mice were observed for clinical signs of infection for $4 \mathrm{~h}$ after injection. The bacterial loads in the peritoneum were thereafter determined by sampling peritoneal fluid for the determination of CFU $4 \mathrm{~h}$ after treatment. The colony counts in peritoneal fluid were determined $5 \mathrm{~h}$ post-inoculation. All animal experiments were conducted in compliance with the institutional guidelines of SSI.

Bacterial Membrane Integrity Assay. The real-time membrane integrity assay was modified from Virta et al. ${ }^{37}$ The test strains were $B$. subtilis 168 (ATCC 23857) and E. coli HB101 carrying the plasmid pCSS962. Overnight cultures were grown in MHB with chloramphenicol $(5 \mu \mathrm{g} / \mathrm{mL}$ B. subtilis and $20 \mu \mathrm{g} / \mathrm{mL}$ E. coli, Merck KGaA, Darmstadt, Germany). The bacteria were pelleted by centrifugation for $5 \mathrm{~min}$ at $4000 \mathrm{~g}$ before they were resuspended in MHB to obtain an $\mathrm{OD}_{600}$ of 0.1. D-Luciferin potassium salt ( $\mathrm{pH} 7.4$, SynChem Inc, IL, USA) was added to a final concentration of $1 \mathrm{mM}$, and the background luminescence was measured. Black round-bottomed 96well microplates (Nunc, Roskilde, Denmark), containing dilutions of the test compounds ( $5 \mu \mathrm{L}$ per well), were loaded into a Synergy $\mathrm{H} 1$ Hybrid Reader (BioTek, Winooski, VT, USA). The amine barbiturate 6e $(3,5-\mathrm{di}-\mathrm{Br})$ and the guanidine barbiturate $7 \mathrm{e}(3,5-\mathrm{di}-\mathrm{Br})$ were screened for membrane activity by injecting $95 \mu \mathrm{L}$ of inoculum with D-luciferin successively (well by well) to the test wells by an automatic injector with tracking of the luminescence emission every second for $150 \mathrm{~s}$ at room temperature. CHX acetate (Fresenius Kabi, Halden, Norway) was used as a positive control.

Bacterial Viability Assay. The compounds 6e (3,5-di-Br) and 7e (3,5-di-Br) were also selected for the viability assay. The test strains were B. subtilis 168 and E. coli HB101 carrying a constitutively expressed lux operon as a chromosomal integration of the lux operon in the $s a c A$ locus (PliaG) or the plasmid pCGLS-1, respectively. ${ }^{43,44}$ The bacterial suspension for the real-time viability assay was prepared as described for the membrane integrity assay with the exception that no external substrate was added and that $100 \mu \mathrm{g} / \mathrm{mL}$ of ampicillin was used for selection of E. coli carrying the plasmid pCGLS-11. The assay 
was performed using the same type of microplates and procedure as described in the membrane integrity assay.

Structural Investigations. Electronic Structure Calculations. Quantum electronic structure calculations were performed at the DFT level of theory with the Gaussian 16 package, ${ }^{45}$ employing the B3LYP functional ${ }^{46,47}$ with empirical dispersion corrections as formulated by Grimme $^{48}$ (B3LYP-GD3). Ground-state optimizations used the 6-31g basis set with additional diffuse $(+)$ and polarization functions $(\mathrm{d}, \mathrm{p})$ for accurate description of neutral and charged species, 6-31 + $\mathrm{g}(\mathrm{d}, \mathrm{p}) .{ }^{49,50}$ Solvent effects were included in all calculations via the polarized continuum method, with water as the solvent. ${ }^{51,52}$ Additional single-point energy calculations were performed with the larger $6-311++\mathrm{g}(2 \mathrm{~d}, 2 \mathrm{p})$ basis set. The larger basis set is expected to provide more accurate energies compared to the smaller 6-31+ $\mathrm{g}(\mathrm{d}, \mathrm{p})$ by providing more flexibility to the electron density, especially in the case of charged groups. Calculated energy Hessians confirmed stationary points as minima (zero imaginary frequencies). The reported electronic energies are given in $\mathrm{kcal} / \mathrm{mol}$.

Nuclear Magnetic Resonance. All spectra were acquired on a Bruker Avance III HD spectrometer operating at $600 \mathrm{MHz}$ for protons and equipped with an inverse TCI probe with cryogenic enhancement for ${ }^{1} \mathrm{H},{ }^{2} \mathrm{H}$, and ${ }^{13} \mathrm{C}$. NMR samples were prepared by dissolving $1 \mathrm{mg}$ of $7 \mathrm{e}$ in $500 \mu \mathrm{L}$ of $\mathrm{H}_{2} \mathrm{O} / \mathrm{D}_{2} \mathrm{O}$ 9:1 in a $5 \mathrm{~mm}$ NMR tube. SDS was subsequently added to this sample in a 20:1 $\mathrm{M}$ ratio, resulting in a clear solution. Experiments were acquired using TopSpin 3.2, with gradient selection, adiabatic pulses, and excitation sculpting where applicable.

$M D$ Simulation. An E. coli inner membrane model was adapted from Pandit and Klauda (2012) with a 4:1 PE/PG ratio. ${ }^{39}$ Systems for $\mathrm{MD}$ simulations of the membrane and for each molecule $\mathbf{6 a}\left(4-\mathrm{CF}_{3}\right)$, 6e (3,5-di-Br), 6g (4-tBu), 7e (3,5-di-Br), and 7g (4-tBu) were prepared in VMD. ${ }^{53}$ Each molecule was placed approximately $8 \AA$ from the membrane surface and oriented such that the direct interactions of the guanidine and lysine groups with the membrane surface were not favored. All membrane systems were solvated in a rectangular simulation box with a $0.15 \mathrm{~mol} / \mathrm{L} \mathrm{KCl}$ concentration. In addition to membrane simulations, each of the molecules $6 \mathrm{a}\left(4-\mathrm{CF}_{3}\right)$, 6e (3,5-di-Br), 6g (4-tBu), 7e (3,5-di-Br), and $7 \mathrm{~g}(4-\mathrm{tBu})$ were prepared for water simulations in rectangular simulation boxes. $\mathrm{Cl}^{-}$ ions were added for counterions.

Molecules 6a $\left(4-\mathrm{CF}_{3}\right), 6 \mathrm{e}$ (3,5-di-Br), 6g (4-tBu), 7e (3,5-di-Br), and $7 \mathrm{~g}(4-\mathrm{tBu})$ were built in PyMol. ${ }^{54}$ Each of the compounds was given a starting structure where both phenyl groups are oriented in the up conformation. A simple minimization was performed in the builder tool of PyMol to clean the structures. Each molecule was assigned atom types, parameters, and charges with the CGenff online program. ${ }^{55,56}$

Three parallels of all-atom MD simulations were performed for all systems with the molecular modeling software NAMD and the CHARMM36 force field. ${ }^{57,58}$ A 10,000 step conjugate gradient and line search minimization was performed to ensure a stable starting structure for the MD simulations. Each membrane system parallel was run for $260 \mathrm{~ns}$, and each water system parallel was run for $100 \mathrm{~ns}$. All simulations were run at $310.15 \mathrm{~K}$ with a $2 \mathrm{fs}$ time step and periodic boundary conditions.

Particle Mesh Ewald was used for calculating the electrostatic interactions. ${ }^{59}$ For non-bonded interactions, the scaled $1-4$ principle was used for exclusion and 1.0 was used for scaling coefficient. A smoothing function was applied to the non-bonded forces with a cutoff of $12.0 \AA$ and a switching distance of $10.0 \AA$. A pair list for the calculation of non-bonded interactions was updated every 20 steps, called one cycle, and the maximum distance for inclusion in the pair list for a pair of atoms was set to $16.0 \AA$. The pair list was regenerated twice every cycle. Bond lengths for hydrogen atoms were constrained with the SHAKE algorithm. ${ }^{60}$ Both full electrostatic forces and the non-bonded forces were evaluated at every time step. The NPT ensemble was used for all simulations. Pressure control for the simulations was performed with Nose-Hoover Langevin piston with a target pressure of 1 atm. ${ }^{61,62}$ A flexible simulation cell was used for the membrane system. Langevin dynamics were used for temperature control. Trajectory files were written every 1000 steps and energies were recorded every 125 steps.

Analysis of the MD trajectories was performed with the VMD GUI and VMD scripts. Figures were made with VMD and PyMol, and all graphs were generated with pandas, seaborn, and Matplotlib. ${ }^{63-65}$

$X$-ray Crystallography. A rod-like specimen of $7 \mathbf{b}$ (2-Nal) was used for X-ray crystallographic analysis. The X-ray intensity data were measured with the $\mathrm{Cu}$ source $(\lambda=1.54178 \AA)$ of an in-house Bruker D8 Venture system. Frames were integrated using the Bruker SAINT software package, and the structure was solved and refined using the Bruker SHELXTL software package. The structure factors of $\mathbf{7 b}$ have been deposited with the Cambridge Crystallographic Data Centre with deposition number 2026641. The integration of the data using a monoclinic unit cell yielded a total of 21874 reflections to a maximum $\theta$ angle of $66.75^{\circ}$ (0.84 $\AA$ resolution), of which 6692 were independent (average redundancy 3.269, completeness $=99.6 \%, R_{\text {int }}$ $=3.12 \%$, and $\left.R_{\text {sig }}=2.71 \%\right)$ and $5846(87.36 \%)$ were greater than $2 \sigma\left(F_{2}\right)$. The final cell constants were 17.6014(15), 15.4212(12), and $16.0233(17) \AA$ with $\beta=106.833(4)^{\circ}$. The final anisotropic refinement converged with an $R_{1} / \mathrm{w} R_{2}$ of $6.8 / 21 \%$ with a GoF of 1.04. The structure of the asymmetric unit of $7 \mathbf{b}(2-\mathrm{Nal})$ with thermal ellipsoids is shown in Figure S2.

\section{ASSOCIATED CONTENT}

\section{s) Supporting Information}

The Supporting Information is available free of charge at https://pubs.acs.org/doi/10.1021/acs.jmedchem.1c00734.

(PDF)

$1 \mathrm{H}$ and 13C NMR spectra and SFC analysis data of the synthesized compounds; detailed description of the biosensor assays; comprehensive discussion of the conformational analysis; and molecular formula strings and MIC and toxicity data for compounds $\mathbf{6 a}-\mathbf{h}$ and 7a-h (CSV)

\section{AUTHOR INFORMATION}

\section{Corresponding Authors}

Annette Bayer - Department of Chemistry, UiT The Arctic University of Norway, NO-9037 Tromsø, Norway; (- orcid.org/0000-0003-3481-200X;

Email: annette.bayer@uit.no

Morten B. Strøm - Department of Pharmacy, Faculty of Health Sciences, UiT The Arctic University of Norway, NO9037 Tromsø, Norway; (i) orcid.org/0000-0003-19730778; Email: morten.strom@uit.no

\section{Authors}

Marianne H. Paulsen - Department of Pharmacy, Faculty of Health Sciences, UiT The Arctic University of Norway, NO9037 Tromsø, Norway

Magnus Engqvist - Department of Chemistry, UiT The Arctic University of Norway, NO-9037 Tromsø, Norway

Dominik Ausbacher - Department of Pharmacy, Faculty of Health Sciences, UiT The Arctic University of Norway, NO9037 Tromsø, Norway

Trude Anderssen - Department of Pharmacy, Faculty of Health Sciences, UiT The Arctic University of Norway, NO9037 Tromsø, Norway

Manuel K. Langer - Department of Chemistry, UiT The Arctic University of Norway, NO-9037 Tromsø, Norway

Tor Haug - The Norwegian College of Fishery Science, Faculty of Biosciences, Fisheries and Economics, UiT The Arctic University of Norway, NO-9037 Tromsø, Norway; (1) orcid.org/0000-0003-1104-5813 
Glenn R. Morello - Department of Chemistry, UiT The Arctic University of Norway, NO-9037 Tromsø, Norway; Department of Science, Valley City State University, Valley City 58072 North Dakota, United States

Laura E. Liikanen - Department of Chemistry, UiT The Arctic University of Norway, NO-9037 Tromsø, Norway

Hans-Matti Blencke - The Norwegian College of Fishery Science, Faculty of Biosciences, Fisheries and Economics, UiT The Arctic University of Norway, NO-9037 Tromsø, Norway

Johan Isaksson - Department of Chemistry, UiT The Arctic University of Norway, NO-9037 Tromsø, Norway; (1) orcid.org/0000-0001-6287-7594

Eric Juskewitz - Department of Medical Biology, Faculty of Health Sciences, UiT The Arctic University of Norway, NO9037 Tromsø, Norway

Complete contact information is available at:

https://pubs.acs.org/10.1021/acs.jmedchem.1c00734

\section{Notes}

The authors declare no competing financial interest.

\section{ACKNOWLEDGMENTS}

This study was funded by the Research Council of Norway (RCN) (grant nos. 214493/F20 and 224790/O30), UiTThe Arctic University of Norway (project nos. A23260 and 235560), pre-seed grant from Novo Nordisk Fonden (grant no. NNF17OC0030098), and the MABIT programme (grant no. BS0079). The computational work has furthermore received funding from the RCN (grant no. 231706/F20), the Norwegian supercomputing program NOTUR (grant nos. NN4654K and NN9330K), and assistance of computational resources at the Center for Computationally Assisted Science and Technology (CCAST) at North Dakota State University, US. The authors thank professor Ørjan Samuelsen (K-Res/ UNN) for giving us access to multi-drug-resistant clinical isolates. We also thank engineers Alena Didriksen (UNN) and Hege Devold (UiT) for their technical assistance with MIC screening, engineer Elizaveta M. Igumnova (UNN/UiT) for providing compound $3 \mathbf{h}$, Dr. Bjarte Aarmo Lund (UiT) for Xray crystallographic analysis, in vivo studies at Statens Serum Institute (SSI, DK), and MIC studies at the Advanced Microscopy Core Facility (AMCF, UiT).

\section{ABBREVIATIONS}

A. baumannii, Acinetobacter baumannii; B. subtilis, Bacillus subtilis; C. glutamicum, Corynebacterium glutamicum; E. coli, Escherichia coli; E. faecium, Enterococcus faecium; K. pneumoniae, Klebsiella pneumoniae; MRSA, methicillin-resistant S. aureus; $P$. aeruginosa, Pseudomonas aeruginosa; S. aureus, Staphylococcus aureus; VRE, vancomycin-resistant Enterococcus; AMPs, antimicrobial peptides; $\mathrm{Boc}_{2} \mathrm{O}$, di-tert-butyl dicarbonate; $\mathrm{CFU}$, colony-forming units; CHX, chlorhexidine; DBU, 1,8diazabicyclo[5.4.0] undec-7-ene; DFT, density functional theory; DMF, dimethylformamide; DMSO, dimethyl sulfoxide; ESBL-CARBA, extended spectrum $\beta$-lactamase-carbapenemase; HCTU, (2-(6-chloro-1H-benzotriazol-1-yl)-1,1,3,3-tetramethylaminium-hexafluorophosphate); i.p., intraperitoneal; LPS, lipopolysaccharide; MD, molecular dynamics; MIC, minimum inhibitory concentration; MTD, maximal tolerated dose; NMR, nuclear magnetic resonance; PL, phospholipid; PMA, phosphomolybdic acid; RBCs, red blood cells; RLU, relative light units; SMAMPs, synthetic mimics of antimicrobial peptides; TFA, trifluoroacetic acid; THF, tetrahydrofuran

\section{REFERENCES}

(1) World Health Organization. 2019 Antibacterial Agents in Clinical Development: An Analysis of the Antibacterial Clinical Development Pipeline; World Health Organization: Geneva, 2019.

(2) O'Neill, J. Tackling Drug-Resistant Infections Globally: Final Report and Recommendations; www.amr-reveiw.org, 2016.report

(3) Cassini, A.; Högberg, L. D.; Plachouras, D.; Quattrocchi, A.; Hoxha, A.; Simonsen, G. S.; Colomb-Cotinat, M.; Kretzschmar, M. E.; Devleesschauwer, B.; Cecchini, M.; Ouakrim, D. A.; Oliveira, T. C.; Struelens, M. J.; Suetens, C.; Monnet, D. L.; Strauss, R.; Mertens, K.; Struyf, T.; Catry, B.; Latour, K.; Ivanov, I. N.; Dobreva, E. G.; Tambic Andraševic, A.; Soprek, S.; Budimir, A.; Paphitou, N.; Žemlicková, H.; Schytte Olsen, S.; Wolff Sönksen, U.; Märtin, P.; Ivanova, M.; Lyytikäinen, O.; Jalava, J.; Coignard, B.; Eckmanns, T.; Abu Sin, M.; Haller, S.; Daikos, G. L.; Gikas, A.; Tsiodras, S.; Kontopidou, F.; Tóth, Á.; Hajdu, A.; Guólaugsson, Ó.; Kristinsson, K. G.; Murchan, S.; Burns, K.; Pezzotti, P.; Gagliotti, C.; Dumpis, U.; Liuimiene, A.; Perrin, M.; Borg, M. A.; de Greeff, S. C.; Monen, J. C.; Koek, M. B.; Elstrøm, P.; Zabicka, D.; Deptula, A.; Hryniewicz, W.; Caniça, M.; Nogueira, P. J.; Fernandes, P. A.; Manageiro, V.; Popescu, G. A.; Serban, R. I.; Schréterová, E.; Litvová, S.; Stefkovicová, M.; Kolman, J.; Klavs, I.; Korošec, A.; Aracil, B.; Asensio, A.; Pérez-Vázquez, M.; Billström, H.; Larsson, S.; Reilly, J. S.; Johnson, A.; Hopkins, S. Attributable deaths and disability-adjusted life-years caused by infections with antibiotic-resistant bacteria in the $\mathrm{EU}$ and the European Economic Area in 2015: a population-level modelling analysis. Lancet Infect. Dis. 2019, 19, 56-66.

(4) World Health Organization. Global Action Plan on Antimicrobial Resistance (accessed 0402 2017).

(5) Tadesse, M.; Tabudravu, J. N.; Jaspars, M.; Strøm, M. B.; Hansen, E.; Andersen, J. H.; Kristiansen, P. E.; Haug, T. The antibacterial ent-eusynstyelamide B and eusynstyelamides D, E, and F from the Arctic bryozoan tegella cf. spitzbergensis. J. Nat. Prod. 2011, $74,837-841$

(6) Tapiolas, D. M.; Bowden, B. F.; Abou-Mansour, E.; Willis, R. H.; Doyle, J. R.; Muirhead, A. N.; Liptrot, C.; Llewellyn, L. E.; Wolff, C. W. W.; Wright, A. D.; Motti, C. A. Eusynstyelamides A, B, and C, nNOS Inhibitors, from the Ascidian Eusynstyela latericius. J. Nat. Prod. 2009, 72, 1115-1120.

(7) Barykina, O. V.; Snider, B. B. Synthesis of (+/-)-eusynstyelamide A. Org. Lett. 2010, 12, 2664-2667.

(8) Strøm, M. B.; Haug, B. E.; Skar, M. L.; Stensen, W.; Stiberg, T.; Svendsen, J. S. The pharmacophore of short cationic antibacterial peptides. J. Med. Chem. 2003, 46, 1567-1570.

(9) Ghosh, C.; Haldar, J. Membrane-active small molecules: designs inspired by antimicrobial peptides. ChemMedChem 2015, 10, 16061624.

(10) Gunasekaran, P.; Rajasekaran, G.; Han, E. H.; Chung, Y.-H.; Choi, Y.-J.; Yang, Y. J.; Lee, J. E.; Kim, H. N.; Lee, K.; Kim, J.-S.; Lee, H.-J.; Choi, E.-J.; Kim, E.-K.; Shin, S. Y.; Bang, J. K. Cationic amphipathic triazines with potent anti-bacterial, anti-inflammatory and anti-atopic dermatitis properties. Sci. Rep. 2019, 9, 1292.

(11) Jiang, Y.; Chen, Y.; Song, Z.; Tan, Z.; Cheng, J. Recent advances in design of antimicrobial peptides and polypeptides toward clinical translation. Adv. Drug Deliv. Rev. 2021, 170, 261-280.

(12) Giuliani, A.; Pirri, G.; Nicoletto, S. Antimicrobial peptides: an overview of a promising class of therapeutics. Cent. Eur. J. Biol. 2007, 2, $1-33$.

(13) Zasloff, M. Antimicrobial peptides of multicellular organisms. Nature 2002, 415, 389-395.

(14) Hancock, R. E. W.; Haney, E. F.; Gill, E. E. The immunology of host defence peptides: beyond antimicrobial activity. Nat. Rev. Immunol. 2016, 16, 321-334.

(15) Powers, J.-P. S.; Hancock, R. E. W. The relationship between peptide structure and antibacterial activity. Peptides 2003, 24, 16811691. 
(16) Latham, P. W. Therapeutic peptides revisited. Nat. Biotechnol. 1999, 17, 755-757.

(17) Paulsen, M. H.; Ausbacher, D.; Bayer, A.; Engqvist, M.; Hansen, T.; Haug, T.; Anderssen, T.; Andersen, J. H.; Sollid, J. U. E.; Strøm, M. B. Antimicrobial activity of amphipathic $\alpha, \alpha$-disubstituted $\beta$-amino amide derivatives against ESBL - CARBA producing multiresistant bacteria; effect of halogenation, lipophilicity and cationic character. Eur. J. Med. Chem. 2019, 183, 111671.

(18) Hansen, T.; Ausbacher, D.; Flaten, G. E.; Havelkova, M.; Strøm, M. B. Synthesis of cationic antimicrobial $\beta(2,2)$-amino acid derivatives with potential for oral administration. J. Med. Chem. 2011, $54,858-868$.

(19) Wong, O.; McKeown, R. H. Substituent effects on partition coefficients of barbituric acids. J. Pharm. Sci. 1988, 77, 926-932.

(20) Ashnagar, A.; Naseri, N. G.; Sheeri, B. Novel synthesis of barbiturates. Chin. J. Chem. 2007, 25, 382-384.

(21) Huang, H.-M.; Procter, D. J. Radical-radical cyclization cascades of barbiturates triggered by electron-transfer reduction of amide-type carbonyls. J. Am. Chem. Soc. 2016, 138, 7770-7775.

(22) Neumann, D. M.; Cammarata, A.; Backes, G.; Palmer, G. E.; Jursic, B. S. Synthesis and antifungal activity of substituted 2,4,6pyrimidinetrione carbaldehyde hydrazones. Bioorg. Med. Chem. 2014, 22, 813-826.

(23) Gunasekaran, P.; Yim, M. S.; Ahn, M.; Soung, N.-K.; Park, J.-E.; Kim, J.; Bang, G.; Shin, S. C.; Choi, J.; Kim, M.; Kim, H. N.; Lee, Y.H.; Chung, Y.-H.; Lee, K.; EunKyeong Kim, E.; Jeon, Y.-H.; Kim, M. J.; Lee, K.-R.; Kim, B.-Y.; Lee, K. S.; Ryu, E. K.; Bang, J. K. Development of a polo-like kinase-1 polo-box domain inhibitor as a tumor growth suppressor in mice models. J. Med. Chem. 2020, 63, 14905-14920.

(24) Jursic, B. S. A simple method for knoevenagel condensation of $\alpha, \beta$-conjugated and aromatic aldehydes with barbituric acid. J. Heterocycl. Chem. 2001, 38, 655-657.

(25) Jursic, B. S.; Neumann, D. M. Reductive C-alkylation of barbituric acid derivatives with carbonyl compounds in the presence of platinum and palladium catalysts. Tetrahedron Lett. 2001, 42, 4103-4107.

(26) Kotha, S.; Deb, A. C.; Kumar, R. V. Spiro-annulation of barbituric acid derivatives and its analogs by ring-closing metathesis reaction. Bioorg. Med. Chem. Lett. 2005, 15, 1039-1043.

(27) Pei, Y.; Wickham, B. O. S. Regioselective syntheses of 3aminomethyl-5-substituted isoxazoles: A facile and chemoselective reduction of azide to amine by sodium borohydride using 1,3propanedithiol as a catalyst. Tetrahedron Lett. 1993, 34, 7509-7512.

(28) Hansen, T.; Moe, M. K.; Anderssen, T.; Strøm, M. B. Metabolism of small antimicrobial $\beta(2,2)$-amino acid derivatives by murine liver microsomes. Eur. J. Drug Metab. Pharmacokinet. 2012, 37, 191-201.

(29) Gillis, E. P.; Eastman, K. J.; Hill, M. D.; Donnelly, D. J.; Meanwell, N. A. Applications of fluorine in medicinal chemistry. J. Med. Chem. 2015, 58, 8315-8359.

(30) Kim, S.-H.; Semenya, D.; Castagnolo, D. Antimicrobial drugs bearing guanidine moieties: A review. Eur. J. Med. Chem. 2021, 216, 113293.

(31) Andreev, K.; Bianchi, C.; Laursen, J. S.; Citterio, L.; HeinKristensen, L.; Gram, L.; Kuzmenko, I.; Olsen, C. A.; Gidalevitz, D. Guanidino groups greatly enhance the action of antimicrobial peptidomimetics against bacterial cytoplasmic membranes. Biochim. Biophys. Acta 2014, 1838, 2492-2502.

(32) Gabriel, G. J.; Madkour, A. E.; Dabkowski, J. M.; Nelson, C. F.; Nüsslein, K.; Tew, G. N. Synthetic mimic of antimicrobial peptide with nonmembrane-disrupting antibacterial properties. Biomacromolecules 2008, 9, 2980-2983.

(33) Locock, K. E. S.; Michl, T. D.; Valentin, J. D. P.; Vasilev, K.; Hayball, J. D.; Qu, Y.; Traven, A.; Griesser, H. J.; Meagher, L.; Haeussler, M. Guanylated polymethacrylates: a class of potent antimicrobial polymers with low hemolytic activity. Biomacromolecules 2013, 14, 4021-4031.
(34) Yang, S.-T.; Shin, S. Y.; Lee, C. W.; Kim, Y.-C.; Hahm, K.-S.; Kim, J. I. Selective cytotoxicity following Arg-to-Lys substitution in tritrpticin adopting a unique amphipathic turn structure. FEBS Lett. 2003, 540, 229-233.

(35) SSI Novel Polymyxin Derivatives Effective in Treating Experimental Peritoneal E. coli Infection in Mice. https://en.ssi. $\mathrm{dk} /$-/media/arkiv/uk/products-and-services/contract-researchorganization/antimicrobial-evaluation/poster---efficacy-study-in-theperitonitis-model.pdf?la=en (accessed 1802 2021).

(36) Galluzzi, L.; Karp, M. Intracellular redox equilibrium and growth phase affect the performance of luciferase-based biosensors. J. Biotechnol. 2007, 127, 188-198.

(37) Virta, M.; Åkerman, K. E. O.; Saviranta, P.; Oker-Blom, C.; Karp, M. T. Real-time measurement of cell permeabilization with lowmolecular-weight membranolytic agents. J. Antimicrob. Chemother. 1995, 36, 303-315.

(38) Kuyyakanond, T.; Quesnel, L. B. The mechanism of action of chlorhexidine. FEMS Microbiol. Lett. 1992, 100, 211-215.

(39) Pandit, K. R.; Klauda, J. B. Membrane models of E. coli containing cyclic moieties in the aliphatic lipid chain. Biochim. Biophys. Acta 2012, 1818, 1205-1210.

(40) Dixon, E. A.; Fischer, A.; Robinson, F. P. Preparation of a series of substituted fluoromethylnaphthalenes. Can. J. Chem. 1981, 59, 2629-2641.

(41) Clinical and Laboratory Standards Institute. Methods for Dilution Antimicrobial Susceptibility Tests for Bacteria that Grow Aerobically. Approved Standard, M07-A9, 9; CLSI: Wayne, PA, 2012.

(42) Igumnova, E. M.; Mishchenko, E.; Haug, T.; Blencke, H.-M.; Sollid, J. U. E.; Fredheim, E. G. A.; Lauksund, S.; Stensvåg, K.; Strøm, M. B. Synthesis and antimicrobial activity of small cationic amphipathic aminobenzamide marine natural product mimics and evaluation of relevance against clinical isolates including ESBLCARBA producing multi-resistant bacteria. Bioorg. Med. Chem. 2016, 24, 5884-5894.

(43) Radeck, J.; Kraft, K.; Bartels, J.; Cikovic, T.; Dürr, F.; Emenegger, J.; Kelterborn, S.; Sauer, C.; Fritz, G.; Gebhard, S.; Mascher, T. The Bacillus BioBrick Box: generation and evaluation of essential genetic building blocks for standardized work with Bacillus subtilis. J. Biol. Eng. 2013, 7, 29.

(44) Frackman, S.; Anhalt, M.; Nealson, K. H. Cloning, organization, and expression of the bioluminescence genes of Xenorhabdus luminescens. J. Bacteriol. 1990, 172, 5767-5773.

(45) Frisch, M. J.; Trucks, G. W.; Schlegel, H. B.; Scuseria, G. E.; Robb, M. A.; Cheeseman, J. R.; Scalmani, G.; Barone, V.; Mennucci, B.; Petersson, G. A.; Nakatsuji, H.; Caricato, M.; Li, X.; Hratchian, H. P.; Izmaylov, A. F.; Bloino, G. Z.; Sonnenberg, J. L.; Hada, M.; Ehara, M.; Toyota, K.; Fukuda, R.; Hasegawa, J.; Ishida, M.; Nakajima, T.; Honda, Y.; Kitao, O.; Nakai, H.; Vreven, T.; Montgomery, J.; Peralta, J. E.; Ogliaro, F.; Bearpark, M.; Heyd, J. J.; Brothers, E.; Kudin, K. N.; Staroverov, V. N.; Keith, T.; Kobayashi, R.; Normand, J.; Raghavachari, K.; Rendell, A.; Burant, J. C.; Iyengar, S. S.; Tomasi, J.; Cossi, M.; Rega, N.; Millam, J. M.; Klene, M.; Knox, J. E.; Cross, J. B.; Bakken, V.; Adamo, C.; Jaramillo, J.; Gomperts, R.; Stratmann, R. E.; Yazyev, O.; Austin, A. J.; Cammi, R.; Pomelli, C.; Ochterski, J. W.; Martin, R. L.; Morokuma, K.; Zakrzewski, V. G.; Voth, G. A.; Salvador, P.; Dannenberg, J. J.; Dapprich, S.; Daniels, A. D.; Farkas, O.; Foresman, J. B.; Ortiz, J. V.; Cioslowski, J.; Fox, D. J. Gaussian 09, Revision D.01; Gaussian Inc.: Wallingford, CT, 2013.

(46) Becke, A. D. A new mixing of Hartree-Fock and local densityfunctional theories. J. Chem. Phys. 1993, 98, 1372-1377.

(47) Lee, C.; Yang, W.; Parr, R. G. Development of the ColleSalvetti correlation-energy formula into a functional of the electron density. Phys. Rev. B: Condens. Matter Mater. Phys. 1988, 37, 785-789.

(48) Grimme, S.; Antony, J.; Ehrlich, S.; Krieg, H. A consistent and accurate ab initio parametrization of density functional dispersion correction (DFT-D) for the 94 elements H-Pu. J. Chem. Phys. 2010, 132,154104 
(49) McLean, A. D.; Chandler, G. S. Contracted Gaussian basis sets for molecular calculations. I. Second row atoms, $\mathrm{Z}=11-18$. J. Chem. Phys. 1980, 72, 5639-5648.

(50) Krishnan, R.; Binkley, J. S.; Seeger, R.; Pople, J. A. Selfconsistent molecular orbital methods. XX. A basis set for correlated wave functions. J. Chem. Phys. 1980, 72, 650-654.

(51) Tomasi, J.; Mennucci, B.; Cancès, E. The IEF version of the PCM solvation method: an overview of a new method addressed to study molecular solutes at the QM ab initio level. J. Mol. Struct. 1999, 464, 211-226.

(52) Cancès, E.; Mennucci, B.; Tomasi, J. A new integral equation formalism for the polarizable continuum model: Theoretical background and applications to isotropic and anisotropic dielectrics. Chem. Phys. 1997, 107, 3032-3041.

(53) Humphrey, W.; Dalke, A.; Schulten, K. VMD: visual molecular dynamics. J. Mol. Graph. 1996, 14, 33-38.

(54) The PyMOL Molecular Graphics System, Version 2.0; Schrödinger, LLC.

(55) Vanommeslaeghe, K.; MacKerell, A. D., Jr. Automation of the CHARMM General Force Field (CGenFF) I: bond perception and atom typing. J. Chem. Inf. Model. 2012, 52, 3144-3154.

(56) Vanommeslaeghe, K.; Raman, E. P.; MacKerell, A. D., Jr. Automation of the CHARMM General Force Field (CGenFF) II: assignment of bonded parameters and partial atomic charges. J. Chem. Inf. Model. 2012, 52, 3155-3168.

(57) Phillips, J. C.; Braun, R.; Wang, W.; Gumbart, J.; Tajkhorshid, E.; Villa, E.; Chipot, C.; Skeel, R. D.; Kalé, L.; Schulten, K. Scalable molecular dynamics with NAMD. J. Comput. Chem. 2005, 26, 17811802.

(58) Klauda, J. B.; Venable, R. M.; Freites, J. A.; O’Connor, J. W.; Tobias, D. J.; Mondragon-Ramirez, C.; Vorobyov, I.; MacKerell, A. D., Jr.; Pastor, R. W. Update of the CHARMM all-atom additive force field for lipids: validation on six lipid types. J. Phys. Chem. B 2010, 114, 7830-7843.

(59) Darden, T.; York, D.; Pedersen, L. Particle mesh Ewald: an N. $\log (\mathrm{N})$ method for Ewald sums in large systems. J. Chem. Phys. 1993, 98, 10089-10092.

(60) Ryckaert, J.-P.; Ciccotti, G.; Berendsen, H. J. C. Numerical integration of the cartesian equations of motion of a system with constraints: molecular dynamics of n-alkanes. J. Comput. Phys. 1977, 23, 327-341.

(61) Feller, S. E.; Zhang, Y.; Pastor, R. W.; Brooks, B. R. Constant pressure molecular dynamics simulation: the Langevin piston method. J. Chem. Phys. 1995, 103, 4613-4621.

(62) Martyna, G. J.; Tobias, D. J.; Klein, M. L. Constant pressure molecular dynamics algorithms. J. Chem. Phys. 1994, 101, 4177-4189.

(63) McKinney, W. In Data structures for statistical computing in python. Proceedings of the 9th Python in Science Conference: Austin, TX, 2010; pp 51-56.

(64) Michael, W.; The Seaborn Development Team. Mwaskom/ Seaborn, 0.11.0; Zenodo, 2020.

(65) Hunter, J. D. Matplotlib: A 2D graphics environment. Comput. Sci. Eng. 2007, 9, 90-95. 